Prepared for the U.S. Department of Energy under Contract DE-AC05-76RL01830

\title{
International Energy Agency Implementing Agreements and Annexes: A Guide for Building Technologies Program Managers
}

ME Evans PJ Runci

AK Meier
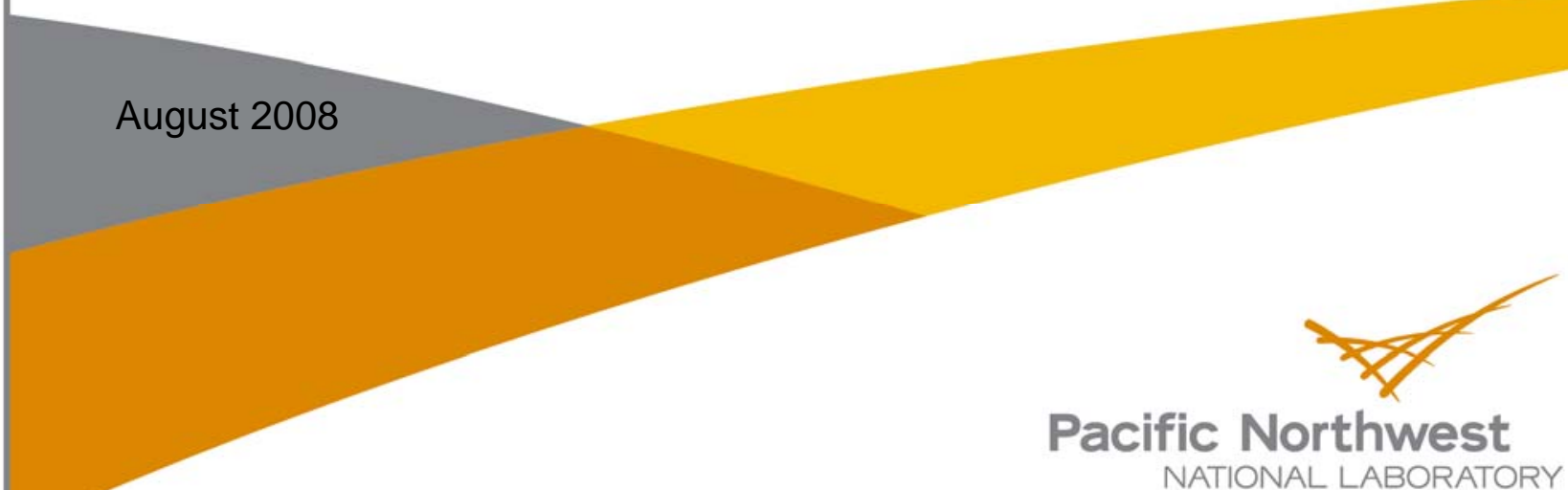


\title{
DISCLAIMER
}

This report was prepared as an account of work sponsored by an agency of the United States Government. Neither the United States Government nor any agency thereof, nor Battelle Memorial Institute, nor any of their employees, makes any warranty, express or implied, or assumes any legal liability or responsibility for the accuracy, completeness, or usefulness of any information, apparatus, product, or process disclosed, or represents that its use would not infringe privately owned rights. Reference herein to any specific commercial product, process, or service by trade name, trademark, manufacturer, or otherwise does not necessarily constitute or imply its endorsement, recommendation, or favoring by the United States Government or any agency thereof, or Battelle Memorial Institute. The views and opinions of authors expressed herein do not necessarily state or reflect those of the United States Government or any agency thereof.

\author{
PACIFIC NORTHWEST NATIONAL LABORATORY \\ operated by \\ BATTELLE \\ for the \\ UNITED STATES DEPARTMENT OF ENERGY \\ under Contract DE-AC05-76RL01830
}

Printed in the United States of America
Available to DOE and DOE contractors from the Office of Scientific and Technical Information,
P.O. Box 62, Oak Ridge, TN 37831-0062;
ph: (865) 576-8401
fax: $(865)$ 576-5728
email: reports@adonis.osti.gov

\begin{abstract}
Available to the public from the National Technical Information Service, U.S. Department of Commerce, 5285 Port Royal Rd., Springfield, VA 22161 ph: (800) 553-6847 fax: $(703) 605-6900$ email: orders@ntis.fedworld.gov online ordering: http://www.ntis.gov/ordering.htm
\end{abstract}

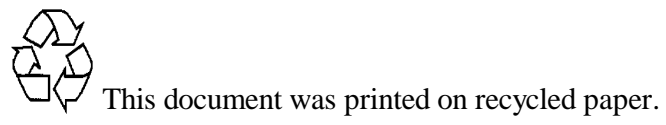




\section{International Energy Agency Implementing Agreements and Annexes: A Guide for Building Technologies Program Managers}

M Evans

AK Meier

PJ Runci

August 2008

Prepared for the U.S. Department of Energy under Contract DE-AC05-76RL01830

Pacific Northwest National Laboratory

Richland, Washington 99352 


\begin{abstract}
This report presents results from a program evaluation of the U.S. Department of Energy's Buildings Technologies Program (BTP) participation in collaborative international technology implementing agreements. The evaluation was conducted by researchers from the Pacific Northwest National Laboratory and the Lawrence Berkeley National Laboratory in the fall of 2007 and winter 2008 and was carried out via interviews with stakeholders in four implementing agreements in which BTP participates, reviews of relevant program reports, websites and other published materials. In addition to these findings, the report includes a variety of supporting materials such that aim to assist BTP managers who currently participate in IEA implementing agreements or who may be considering participation.
\end{abstract}

KEY WORDS: implementing agreement, annex agreement, international technology collaboration, buildings technologies, International Energy Agency 
Table of Contents

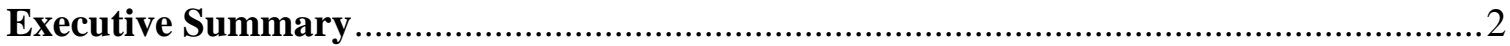

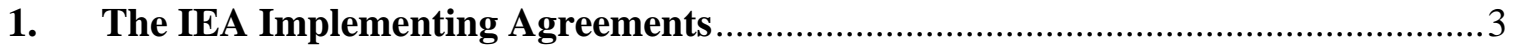

1.1. Overview of Building-Related IEA Implementing Agreements.............................3

1.2. Technology Collaboration through the IEA......................................................

1.3. Elements of a Successful Project ......................................................................... 5

1.4. National Teams and Other Ways to Encourage Domestic Cooperation

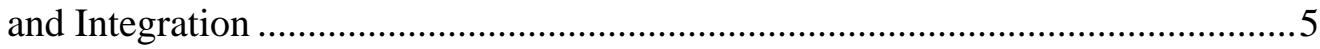

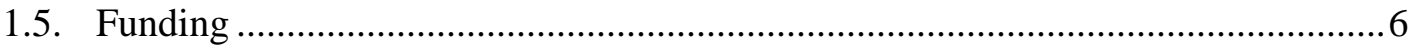

2. DOE Participation in IEA Implementing Agreements: Summary of

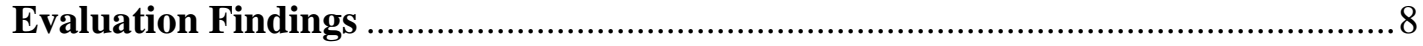

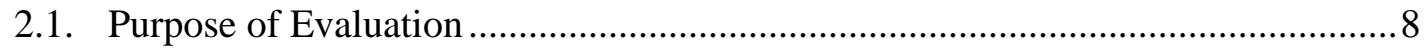

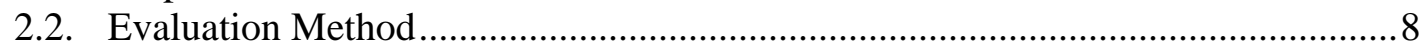

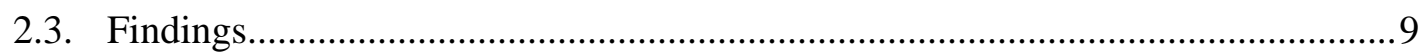

3. Mapping IEA Implementing Agreement Activities to BTP

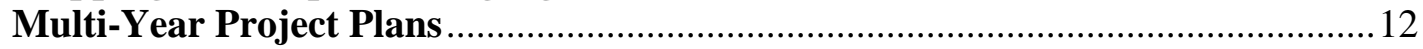

3.1. Brief Summaries of MYPP-IA Mapping ........................................................ 12

3.1.1. Heating, Ventilation, and Air Conditioning (HVAC) ............................12

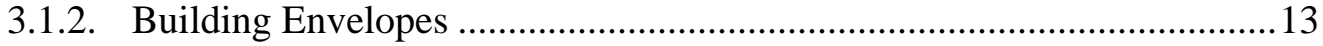

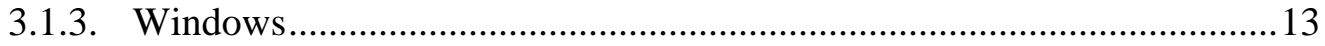

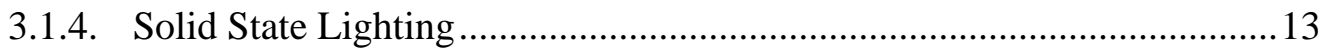

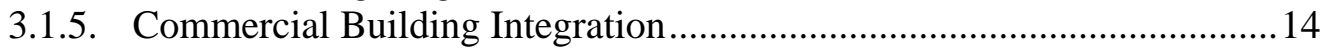

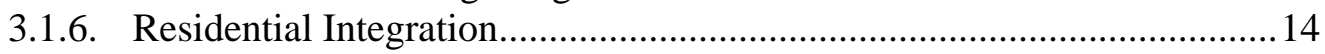

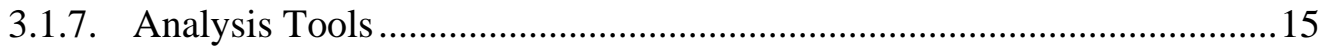

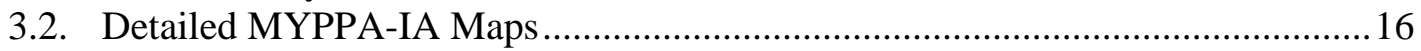

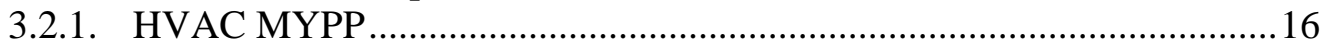

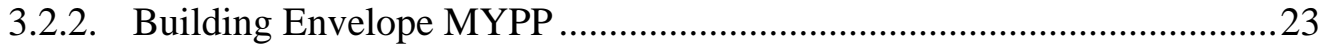

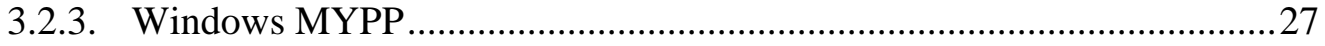

3.2.4. Commercial Building Integration MYPP ..........................................22

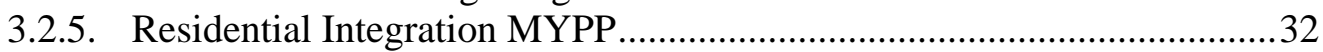

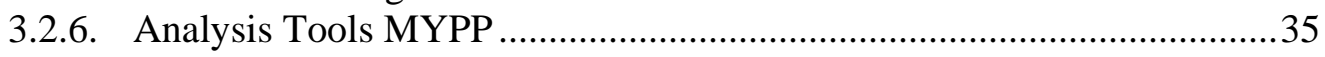

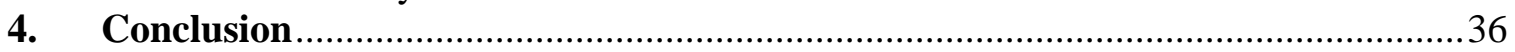

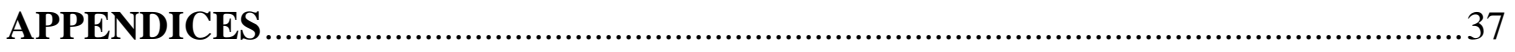

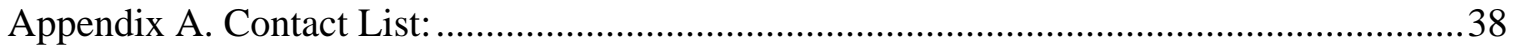

Appendix B. Evaluation Interview Questionnaire ..............................................................

Appendix C. Recent Highlights of DOE-sponsored Participation in IEA IAs ........................50

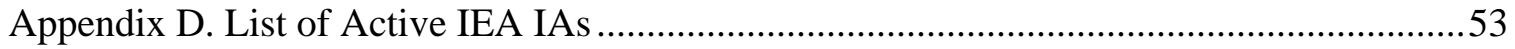

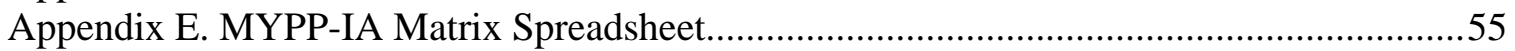

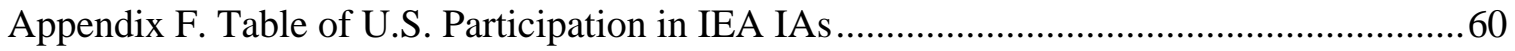

Appendix G. Presentation of PNNL-LBL Interim Evaluation Findings ................................70

Appendix H. Current Annexes of the Energy Conservation in Buildings \& Community

Systems, Demand-Side Management, District Heating \& Cooling, and Heat

Pumping Technologies Agreements....................................................................... 93

Appendix I. Notes From Building Technologies Program IEA Day, May 8, 2008 ...............97

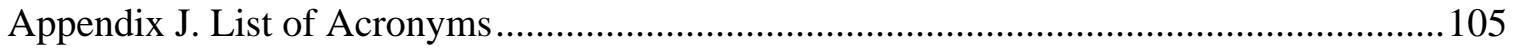

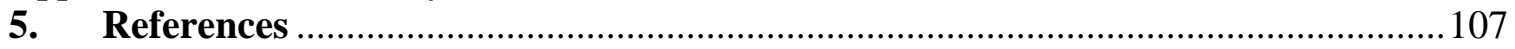




\section{Executive Summary}

DOE's Building Technologies Program (BTP) within its Office of Energy Efficiency and Renewable Energy (EERE) has participated in International Energy Agency (IEA) implementing agreements (IAs) and annexes since the 1970s. IAs have offered BTP a reliable platform for international technology collaboration, streamlining the process of multilateral agreement formation and providing an accepted and transparent legal framework for cooperation. An IA is are most often selected as a vehicle for technology collaboration when new, proprietary intellectual property is unlikely to result and in cases where international information exchange, technology demonstration or cooperation on public domain decision support tools is viewed as mutually beneficial and noncontroversial among participants.

This report includes results of an evaluation of BTP's current participation in IEA IAs and procedural guidance for BTP staff who manage these relationships. The evaluation was conducted by researchers from the Pacific Northwest National Laboratory and the Lawrence Berkeley National Laboratory in FY08. The researchers interviewed active participants in the IAs in which BTP is currently involved or that closely relate to BTP's work. ${ }^{1}$ Interviewees included representatives of industry, government agencies (including BTP program managers), and research institutions in the U.S. and abroad. Evaluation researchers also reviewed several relevant websites (including some dedicated to the IAs themselves) that published reports, IA newsletters and financial information provided by DOE and the IEA.

The evaluation found that BTP program managers strongly believe that international collaboration through IEA IAs delivers significant value to BTP, DOE, and U.S. industry for relatively small commitments of resources. Other U.S. and foreign participants in the evaluation echoed these beliefs, and, although some interviewees offered criticisms of the operation of particular IAs or annexes, none questioned the overall benefit and value of the IA as a vehicle for technology cooperation.

IAs are generally considered valuable, but there are no established metrics within BTP for the costs and benefits/value associated with IAs. BTP has not typically established evaluation metrics or criteria from the outset of its participation in an IA or annex, nor has it often considered its participation as a strategic activity that could or should be aligned with strategic objectives specified in its Multi-Year Program Plans. BTP managers recognized the need for better integration of IEA IAs and other international activities into the main BTP portfolio and plan to take additional steps-including the creation of an improved internal communication system for IA managers and sponsorship of an EERE-wide symposium on international activities-during the upcoming fiscal year (FY 2009).

\footnotetext{
${ }^{1}$ The three IAs in which BTP currently participates are Energy Conservation in Buildings and Community Systems, Heat Pumping Technologies and Solar Heating and Cooling. The other IAs considered in this evaluation are Demand Side Management and Energy Efficient Electrical Equipment.
} 


\section{The IEA Implementing Agreements}

This document presents analysis and insights drawn from the U.S. Department of Energy's (DOE's) longstanding and extensive participation in International Energy Agency (IEA) implementing agreements (IAs) and annexes. DOE has been a key participant in international research activities through the IEA since the 1970s. Recognizing the importance of documenting the experience, knowledge, and institutional memory associated with these activities, DOE seeks to assemble in a single reference learning that has occurred through participation in IEA IAs as a guide for managers in DOE's Office of Building Technologies Program (BTP) currently responsible for IAs.

This document also includes an assessment of BTP's experience with IAs. BTP is now a key player in three IAs, and two additional IAs may also offer opportunities for participation. However, the relative costs and benefits of its involvement have not been assessed for several years. This report presents the results of a research project conducted by the Pacific Northwest National Laboratory and Lawrence Berkeley National Laboratory in FY08. The findings included here were drawn from interviews with more than 50 individuals in the United States and abroad and from government, industry, the IEA and professional associations, each of whom has been involved in the operation of IAs. The research team also drew its findings from documents provided by BTP and IEA and from internet-published materials regarding each of the five IAs under examination.

\subsection{Overview of Buildings-Related IEA Implementing Agreements}

The buildings technology area has proven a rich one for international collaboration since the IEA's founding in the 1970s. While buildings are inherently local objects, the wide range of technologies used in their design, construction and operation are international and evolve continually. For this reason, it is essential for DOE to keep abreast of research and technical developments throughout the world, many of which may fill specific needs in the United States or in BTP's research plans. Likewise, innovations supported or developed by BTP may fill needs in other countries and may lead to important export opportunities for U.S. firms.

The IEA holds a central position in international science and technology collaboration in building-related energy technology and many other areas, largely because it offers a widely accepted legal framework for international collaboration, the Implementing Agreement (IA). Because most IEA member countries have participated in IAs and have had success with them, IAs are broadly regarded as reliable and efficient mechanisms for collaboration in some areas. In the absence of such a framework, the transaction costs associated with the start-up of international collaborative projects can easily be prohibitive. IEA IAs play particularly important roles as tools for both informationgathering and multilateral cooperative research on projects that are less likely to yield proprietary intellectual property.

Presently, five IAs, three of which the United States participates in, cover activities relevant to BTP. Many participants in these IAs and their annexes consider them to be 
valuable assets because they give BTP an international perspective on a detailed technical area or allow BTP to benefit from relevant research conducted outside the United States. This document aims to help BTP managers derive as much benefit as possible from IAs by familiarizing them with the structure, formation, and operation of IAs and annexes.

\subsection{Technology Collaboration through the IEA}

The IEA Secretariat facilitates the creation and operation of the IAs. ${ }^{2}$ It formally oversees the IAs and ensures that the IAs fulfill their legal and financial obligations. In practice, the IAs operate with a high degree of autonomy, and participants interact only occasionally with the IEA Secretariat in Paris. ${ }^{3}$ BTP staff currently interact with only a few of the 40+ IAs:

- Energy Conservation in Buildings and Community Systems (ECBCS),

- Heat Pumping Technologies (HP),

- Solar Heating and Cooling (SHC),

- Demand-Side Management (DSM), and

- Energy-Efficient Electrical Equipment (4E).

The precise structure of each IA depends on its charter, which provides its legal foundation. However, an executive committee ("ExCo") always supervises the activities of an IA. Groups of countries tackle specific topics in annexes inside the IA. The actual business of exchanging ideas, exploring new technologies, and coordinating research, takes place within annexes (sometimes called tasks).

BTP staff often serve on the ExCos. The twice-yearly ExCo meetings, while mostly administrative in nature, establish directions for existing and new annexes. If, for example, BTP wants to establish an annex inside ECBCS on highly-insulated windows, informal and eventually formal discussions would begin in the ExCo. The informal exchanges are particularly important because here participants learn about research in other countries about to begin, early results, or key aspects that never get published.

Researchers and contractors will typically attend the annex meetings. However, BTP staff may also need to participate in annexes to participate in expert meetings, planning sessions, or simply to gather intelligence.

\footnotetext{
${ }^{2}$ The IEA's website is www.iea.org. Those interested can search the site for "implementing agreements" or simply enter http://www.iea.org/Textbase/techno/index.asp. The IEA has also recently begun using a new term for the implementing agreements, "technology agreements," which more accurately describes them. Nonetheless, they are still referred to as "implementing agreements" for legal purposes.

${ }^{3}$ The IAs regularly report their activities to the Committee on Energy Research and Technology (CERT) in the IEA. There are a few other administrative functions, but these are not important for understanding the overall arrangement.
} 


\subsection{Elements of a Successful Project}

What are the ingredients of a successful project? There is no simple way of predicting success of a project. An element that greatly increases the likelihood of success is that all participating countries see important benefits. For example, a project that no country could undertake alone will be attractive to multiple particpants. Thus, databases, modeling tools, test procedures, and validations are more likely to find willing participants and successful results than collaborations seeking to develop new materials or devices. From BTP's perspective, a successful project has benefits that exceed the costs; in many cases this happens when BTP expects to be a "net importer of information." By taking a more strategic view of its involvement, BTP can work to increase the net benefits of its participation in current IAs and develop more successful projects through the IEA in the future.

\subsection{National Teams and Other Ways to Encourage Domestic Cooperation and Integration}

Several countries-including the United States—have established coordinating bodies at the national level ("national teams") to help guide and organize activities related to a particular IA or annex. In addition to facilitating more cohesive national participation in IAs and annexes, national teams also provide a forum for interactions and collaboration among participants on other projects as well. The national teams are comprised of representatives from industry, research institutions, government agencies, national laboratories, and universities. U.S. national teams serve many key functions:

- Effective dissemination of IA research results,

- Creation of a vehicle for industry funding and support of tasks, and

- Efficient coordination of effort within industry, and among industry, DOE and other research partners.

A good example of coordination within industry is the Demand Response Coordinating Committee under the Demand Side Management IA. This Committee provided a platform for U.S. utilities and system operators to discuss how best to integrate demand response activities into existing power markets. The participants agree that it has been a critical component of integrating demand response as a valuable commodity in U.S. power markets. Getting to this point required close coordination between system operators, power producers, distribution companies, and regulators.

Of the IAs coordinated by BTP, only the Heat Pumping Technologies agreement has a U.S. national team, which is coordinated by Oak Ridge National Laboratory. This team serves as a forum in which industry, research institutions, and government agencies can discuss research priorities, emerging opportunities and progress on ongoing tasks; the team meets at least annually, usually in conjunction with major industry association conferences (e.g., American Society of Heating, Refrigeration and Air-Conditioning Engineers). Several of those who were interviewed in the course of this evaluation mentioned the U.S. Heat Pump national team as an exemplar or best practice. 
Creating a national team involves effort, even when industry pays much of the additional cost. Criteria can be helpful in balancing the costs and the benefits of national teams. First, national teams primarily make sense when the volume of work and timeframe in which it will be conducted warrant the initial effort to pull the team together. Thus, national teams are most often formed at the IA level, rather than at the annex level, since annexes usually have a brief, two-year lifespan. Second, national teams are particularly important when there is a critical need to share information with industry. Industry's interest in participation often grows as technologies move closer to the commercialization stage. Third, national teams are important when industry has more experience than government officials or researchers in a particular technical area since teams allow industry to have a more prominent role in determining the direction of IA-related activities. This is particularly true in research on the results of practical experience, such as building retrofits. Finally, industry's willingness to pay is a good measure of the value industry sees from national team participation, and as such, may be a litmus test in deciding whether to form a national team.

Whether it makes sense to create a national team as a formal institution or as a more ad hoc group depends to a large extent on the amount of funding available and the extent of funding that may be provided by industry. Creating separate institutions, like the Demand Response Coordinating Committee, makes it much easier for private companies to fund part of the research. If no private financing is anticipated, or if the volume of investment is small and involves only task-sharing, more ad hoc approaches to national teams are better choices. An ad hoc approach might be to conduct bi-annual meetings of key industry representatives with IA researchers and DOE staff to discuss specific research areas.

\subsection{Funding}

Flexibility in financing is one of the benefits of the IAs. IAs require an annual contribution on the part of participating countries, but most other costs depend on the number and type of annexes in which a country participates. An annex may rely on direct payments (pooled to support a specific researcher), or on in-kind contributions such as support of a researcher in a U.S. laboratory, university or firm, loaned staff, equipment, or materials.

Many research collaborations require multi-year commitments. Since the annual appropriations process places inherent limitations on BTP's ability to make longer-term funding commitments, BTP's entry into some IAs and annexes may be restricted. In any case, an analysis of longer-term financial commitments associated with participation in a given IA should be part of the decision process in consideration of joining an IA or annex. Other IEA countries rely heavily on industry for co-funding annex activities in which they participate. BTP staff should also pursue industry co-funding as a means of managing costs and broadening U.S. participation in IAs. 
It is as important to document the costs and benefits of collaboration through IAs, as it is with domestic research activities. At a minimum, IA activities should demonstrate alignment with BTP Multi-Year Project Plans (MYPPs) or other objectives. In the survey, BTP staff often noted that many of the benefits are intangible and arise from the formal and informal information exchanges at ExCo meetings and national team meetings. These discussions often play an important role in identifying new research areas and, equally importantly, in suggesting areas to avoid in future research efforts. Estimating the broader stream of benefits to all U.S. stakeholders (firms, government agencies, industry associations, and research institutions) is difficult. However, the continued willingness of each of these constituencies to allocate staff time and funding for participation suggests that a wide range of constituencies value the IAs sufficiently to merit ongoing commitments to them.

Estimating the direct and indirect costs to BTP of participation in IAs is complicated by a lack of readily available and consistent financial data for each IA. The sparse financial data gathered in the course of this evaluation were assembled from a combination of IEA and DOE sources and are presented in the table below.

Table 1. BTP Financial Support for IEA IAs and Annexes

\begin{tabular}{|l|l|l|}
\hline Implementing Agreement & No. Active Annexes & $\begin{array}{l}\text { BTP Financial } \\
\text { Support }\end{array}$ \\
\hline Heat Pumping Technologies & 2 w/direct costs to BTP & $\begin{array}{l}\text { FY 05: \$250K } \\
\text { FY 06: \$159K } \\
\text { FY 07: \$191K } \\
\text { FY 08: \$250K }\end{array}$ \\
\hline $\begin{array}{l}\text { Energy Conservation in } \\
\text { Buildings and Community } \\
\text { Systems }\end{array}$ & 3 w/direct costs to BTP & FY 08: \$185K \\
\hline Solar Heating and Cooling & 2 w/direct costs to BTP & No data available \\
\hline
\end{tabular}

These data represent costs associated with membership fees, cost-shared research and, to some extent, DOE investments in task-shared research. Cost-shared research takes place when countries pool their funds to invest in a single research project. Task-shared research means that DOE will fund a U.S. national laboratory or other research organization to participate in collaborative international research through specific tasks. 


\section{DOE Participation in IEA Implementing Agreements: Summary of Evaluation Findings}

DOE has been a key participant in collaborative international science and technology agreements coordinated by the IEA since the inception of both agencies in the 1970s. The IEA, through its science and technology IAs, offers an established institutional framework with basic rules and operating procedures that are well-known among potential participants. Familiarity and past experience with IAs consequently avoids the process of establishing a contractual agreement de novo each time IEA member countries decide to work together in a given technology area.

\subsection{Purpose of Evaluation}

Familiarity and convenience are two important attributes of the IEA IA framework, but the value of DOE's participation in IAs is ultimately a question of costs and benefits, broadly defined. With this consideration in mind, we asked three questions related specifically to BTP's participation in IEA IAs:

1. What is BTP's commitment of resources (staff time and direct funding) to IAs and what does it gain from these commitments?

2. Do the benefits of BTP's participation in IAs warrant continued participation at current levels of effort, or should BTP consider adjustments to its portfolio of IEA activities to improve the stream of benefits it receives from its investments?

3. More broadly, what measures might be taken to enhance the value of BTP's participation in IAs?

The evaluation focused primarily on three IAs in which BTP has had long-term involvement (HP, SHC and ECBCS), one IA with clear relevance to BTP even though it is managed by another DOE Program Office (DSM), and one IA that is currently in its start-up phase (4E).

\subsection{Evaluation Method}

Data for the evaluation was gathered from a variety of sources:

1. Interviews with IA participants. We sought as broad a sample as possible by interviewing a variety of IA participants that included DOE program managers, national laboratory program managers, private industry representatives in the U.S. and abroad, IA operating agents, foreign government officials, and trade association representatives. A standardized interview protocol was used as a basis for each of the interviews and is included as Appendix B.

2. IA-related documents. Sources included annual reports for the IAs and their respective annexes/tasks, national team newsletters, official IA websites and associated documents, evaluations conducted by other countries, and supporting materials provided by IA participants. 
3. Financial data. Although limited, financial information on participants' contributions to IAs was provided by BTP program managers and IA annual reports.

After initial data gathering, the research team synthesized its findings and presented them to BTP managers in January 2008. Since then, additional interviews and data gathering efforts have aimed to improve the robustness of research findings, summarized below.

\subsection{Findings}

The research team found that the IAs offer significant benefits to BTP, DOE and U.S. industry. Specific benefits include the following:

- Timely information on international state-of-the-art in key technology areas. Several government and industry participants noted that one of the greatest values of participation in an IA is its "intelligence gathering" function. Through IA international meetings, national team meetings, and newsletters, participants gain access to up-to-date information on technological developments in their areas of interest. Government representatives noted that international exchanges through IAs often provide information on innovations in codes, standards, and best practices. In some technology areas (e.g., heat pump technologies) where other countries have a technological lead, U.S. firms can avoid costly duplications of effort and identify strategic market strengths and weaknesses. Even though the collaborative work undertaken via IAs seldom results in new intellectual property, the information value of collaboration makes it worthwhile for most participants in the United States and abroad,

- Leveraging of research resources. IAs and their annexes facilitate research that would not be possible otherwise. They can do so by providing a space for collaboration on large-scale systems and complex research problems. For example, the building simulation benchmarking model (Building Energy Simulation Test or BESTEST) was developed and refined collaboratively under the Energy Conservation in Buildings and Community Systems IA by multiple participating countries over five years; the BESTEST annex maintains a library of high-quality international empirical validation datasets for a wide variety of building design conditions available to participating countries. Similarly, new equations of state for chlorofluorocarbon (CFC) replacements were worked out collaboratively through an IA framework, and

- Intra-industry collaboration. IAs can help to consolidate industry participants and stimulate dialogue and cooperation, especially through the formation of national teams. National teams provide a locus of coordination and cooperation for IA participants within a given country and provide industry participants with a forum in which they can determine priorities, key issues and problems, and strategic approaches to markets and other IA participating countries. While several foreign 
countries have national teams for many of the IAs in which they participate, the Heat Pump Technologies IA is the only BTP-managed IA for which the United States has a national team, coordinated by Oak Ridge National Laboratory. National teams typically meet multiple times annually at participants' expense, often in conjunction with other industry association meetings (e.g., the American Society of Heating, Refrigerating and Air Conditioning Engineers [ASHRAE]).

\section{Box 1. Results of IA Evaluations from Other Countries}

Several IEA countries have prepared evaluations on the implementing agreements over the years. The most recent evaluations include ones by Australia, Austria, Finland, Germany, New Zealand, the Netherlands, Sweden, Turkey, and the UK. The IEA Secretariat noted that these evaluations generally were very favorable in terms of the usefulness of the agreements, but some found that better dissemination of results would help maximize their domestic value. The research team was able to review the evaluations by Austria and Germany. Germany conducted an extensive survey of people involved in the implementing agreements to get their feedback. The German evaluation found that the IAs are useful and practical, and participants all had a high opinion of the IAs. Avoiding duplicative research was one of the positive impacts noted, as was the forum for exchanging information that the IAs created. At the same time, the German evaluation noted that it was difficult to find metrics to measure market impact, and dissemination of information within the German specialist community could be expanded. Austria found that participation in the preceding 5 years had led to 21 new international collaborations and new IP. In addition, based on their evaluations, several countries decided to set up domestic networks for coordination on implementing agreements. In many cases, this involves a website with IEA-related information and links. In other cases, it involves periodic meetings among IA researchers and/or industry officials.

In addition to these major benefits, there are also ongoing challenges associated with participation in IAs:

- Coordination/information dissemination within DOE. Mechanisms for distributing information regarding IAs and annexes to stakeholders within DOE include occasional newsletters prepared by program managers, trip reports from DOE staff members attending IA ExCo meetings, and informal communications with interested individuals, usually initiated by program managers. More formal mechanisms for communication within DOE (e.g., listserves, websites, periodically scheduled meetings among program managers and other BTP managers, formation of national teams) might help DOE to gain additional value from participation in IAs and help program managers demonstrate the many benefits of involvement in these agreements, 
- Lack of financial data. Assessing the value and benefits of DOE's participation in IEA IAs is complicated by the lack of consistent and reliable information on the resources DOE devotes to these relationships. Although it may be difficult to estimate contributions in kind, principally staff time, direct contributions in the form of membership fees, funding to national laboratories for participation in IArelated activities, and IA-related travel expenditures could be more easily quantified. There is currently no consistent accounting for these investments within BTP, and

- Scarce travel funding. BTP program managers have repeatedly noted their difficulties in securing travel funding and authorization to attend IA ExCo meetings and other IA-related activities. Research suggests that these problems may stem in part from communication barriers between project managers and upper managers, primarily an insufficient level of understanding of the benefits of IA-related activities on the part of upper level managers. Efforts to improve information dissemination and availability, as described above, could play a major part in addressing the apparent communication problems within BTP. 


\section{Mapping IEA Implementing Agreement Activities to BTP Multi-Year Project Plans}

As noted earlier, participation in IEA IAs is best justified when collaborative activities carried out within a given agreement advance BTP strategic goals and objectives. The benefits of participation in IAs and annexes/tasks often extend beyond direct contributions to BTP strategic goals, for instance by furthering goals of particular U.S. industries or firms, providing opportunities for learning about new and emerging technologies and policy tools, and enhancing communications between DOE and industry. Nonetheless, since IEA IAs entail commitments of DOE funding and staff time, de minimis criteria for participation should be close correspondence between BTP and IA activities and a reasonable expectation of strategic benefit to BTP.

In an effort to assess the degree of benefit to BTP from its participation in IAs, this section provides a series of "maps" drawing linkages between IA activities and objectives specified in BTP's MYPPs. In addition to describing current connections and synergies, the maps may help BTP managers to identify critical gaps and areas for possible future collaboration through the IEA. In this capacity, the maps could provide a useful strategic tool allowing BTP managers to identify key emerging research areas where the formation of new IAs or annexes might help U.S. industry to attain a leadership position or to advance other priority energy and environmental objectives. Ideally, BTP's engagement would be strongest in areas where it has a strategic interest and where it is clear that there is significant international research. The maps below identify some areas where there are such intersections. However, IAs do not always exist where there is vibrant international research, although participation in IAs can help in identifying such areas.

This section summarizes the relevant findings of the mapping exercise by MYPP. Detailed maps follow in the next section of this document. In addition, Appendix E provides a matrix with a visual summary of the relevant areas of intersection.

\subsection{Brief Summaries of MYPP-IA Mapping}

The following summaries provide brief overviews of the linkages between strategic objectives included in BTP MYPPs and ongoing activities carried out through IEA IAs and annexes. The activities described here are specified in greater detail below in the more extensive maps provided in section 3.2.

\subsubsection{Heating, Ventilation, and Air Conditioning (HVAC)}

There are at least two IEA IAs with active annexes that are directly aligned with BTP priorities as specified in the HVAC MYPP: The Heat Pump IA and Energy Conservation in Buildings and Community Systems. Many of the activities carried out under these agreements are particularly relevant to priorities specified under headings 4.5 "Critical Research and Development (R\&D) Programs" and Critical R\&D Priority 4.5.1 "HVAC" in the BTP HVAC MYPP. Particularly strong linkages to the HP IA are found in the ground source heat pump technology area (Annex 34). Key linkages with the Energy 
Conservation in Buildings and Community Systems IA include activities in air infiltration and ventilation (Annex 5) and the low exergy systems technology area (Annex 49). While there is a strong likelihood that activities under these agreements also are relevant to Critical R\&D Priority 4.5.2 "Water Heating" and 4.5.3 "Appliances, Controls, and Miscellaneous," direct linkages and parallel activities are less apparent based on comparisons of the MYPP and IA texts and supporting documentation.

\subsubsection{Building Envelopes}

IEA IAs have relevance for several elements of the current Envelope MYPP. Most of the IA work focuses on collecting best practices and cutting edge research from participating countries, which can provide useful insights to BTP on technology developments globally. ECBCS has the broadest resources related to building envelopes. For example, Annex 44 of that agreement involves a review of $R \& D$ related to reactive building elements and optimized design in the participant countries. These elements include phase change materials for roofs, ventilated and double skin facades, and foundations that maximize energy efficiency through better integration with the environment. Other ECBCS annexes are also relevant. Annex 39 focuses on high performance, compact insulation. There are also annexes that look at ventilation in the building façade (Annex 5, which sponsors an air ventilation center, and Annex 44). Advanced wall systems are also covered in Annex 50, on prefabricated elements for advanced retrofit systems, ${ }^{4}$ and the SHC, Annex 37 on Advanced Housing Renovation with Solar and Conservation. Annex 41 covers heat and moisture issues affecting the whole building. In addition, ECBCS (Annex 43) and the SHC (Annex 34) have jointly developed the BESTEST, which has become an international standard to validate building energy simulation programs.

\subsubsection{Windows}

Curiously, no annexes presently address window technologies in a concentrated way. Several annexes examine narrowly focused issues relating to windows as part of larger efforts. SHC Annex 31 also looked at daylighting for buildings. At the same time, the MYPP identifies significant areas of leading international research related to each of the four planned R\&D projects that BTP will fund. This suggests that the BTP might help to achieve its strategic goals through international cooperation in this area, possibly through a new annex. Proposing an annex has the advantage of ensuring that BTP will get maximum value of the research.

\subsubsection{Solid State Lighting}

BTP currently works on developing energy efficient solid state lighting. The MYPP in this area focuses on core research on product development for both light-emitting diodes (LED) and organic light-emitting diodes (OLED). The ECBCS Annex 45 focuses on

\footnotetext{
${ }^{4}$ This annex focuses on multi-family housing, and as such is not directly applicable to the majority of the U.S. housing stock. For this reason, DOE has not invested in this annex.
} 
efficient lighting. Currently, that annex has a subtask on innovative technical solutions; the subtask examines trends in existing and future lighting technologies.

\subsubsection{Commercial Building Integration}

BTP has adopted a new approach to raise energy efficiency in the commercial building sector. This new approach focuses on collaboration with commercial building owners and operators to design and implement innovative, energy efficient buildings. The R\&D in support of this endeavor will be selected as needed for the collaboration. This may make it challenging to work with IAs given the longer timeframe needed to organize international collaboration. On the other hand, the work done under several existing and past IAs may prove very relevant. This includes both work on approaches (like bulk procurement, which was first examined under the DSM Implementing Agreement) and on specific technology areas (like commissioning). Many of the retail companies that are working with the Commercial Building Integration program through a National Energy Alliance are major international companies. This may mean that they also have an incentive to examine international experience and enhance their global building stock.

\subsubsection{Residential Integration}

BTP's Residential Integration Program focuses on improving the efficiency of new homes through research, development, demonstration and improved technology integration. The current MYPP involves 5 stages or tasks, beginning with analysis of technology pathways, evaluating system performance and performance of specific components in the system, and development and evaluation of a prototype house that then is scaled up to a residential subdivision. As with the commercial integration MYPP, the work involves both methodologies and assessment tools, and development of specific technologies. However, the Residential Integration MYPP has more specifics on technologies that will likely be examined during the plan period-most of these relate to specific building components in Stage 2 of the MYPP.

The IAs are not organized by commercial versus residential buildings, but several IAs cover residential energy efficiency technologies, and other technologies that can be applied in residential buildings. The most relevant IAs are ECBCS, SHC and HP. For almost all the specific research areas, there is relevant research going on within an IA annex. However, the degree of relevance and the extent to which the relevant work is housed in one annex varies across the MYPP tasks. For example, the SHC Task 35 Photovoltaic (PV)/Thermal Solar Systems seems directly relevant to the MYPP subtask on Solar Electric and Thermal (PV/T), as well as to some of the other MYPP tasks related to solar energy. Other MYPP tasks, like those related to hot water distribution, do not have such clear and robust linkages with work in annexes, though the annexes may provide small amounts of specific research in relevant areas. 


\subsubsection{Analysis Tools}

Analysis tools are good candidates for international collaboration and already have a documented history of successes (such as the BESTEST activities through the IEA). Many current and planned activities already link to IEA IAs. Expanded collaboration is possible, depending on the priorities within BTP, and at least three ongoing IAs have active annexes that link to current BTP priorities. For example, the ECBCS IA Annex 42 focuses on the development of tools for the simulation of building integrated fuel cells and other cogeneration systems, while SHC IA Annex 32 is working to develop advanced storage concepts for solar and low energy buildings. Also relevant is HP IA Annex 31, under which one task addresses modeling and tools for the analysis of energy use in supermarkets. BTP participates in each of these and other relevant IA annexes. 


\subsection{Detailed MYPP-IA Maps}

The following tables map BTP MYPPs to IEA IAs and annexes/tasks in which BTP currently participates. Since the MYPPs differ in their organization and structure, the corresponding maps vary in their respective structures and seek to present the IAs and MYPPs in ways that best highlight the linkages among them.

\subsubsection{HVAC MYPP}

Table 2. Map of HVAC MYPP and IEA Implementing Agreements

\begin{tabular}{|c|c|c|c|c|}
\hline $\begin{array}{l}\text { Implementing } \\
\text { Agreement }\end{array}$ & Annex & Selected Tasks & $\begin{array}{l}\text { Annex/Task } \\
\text { Descriptions }\end{array}$ & $\begin{array}{l}\text { Relevant BTP } \\
\text { Critical R\&D } \\
\text { Priority }\end{array}$ \\
\hline $\begin{array}{l}\text { Heat } \\
\text { Pumping } \\
\text { Technologies }\end{array}$ & $\begin{array}{l}\text { Annex 29-- } \\
\text { Ground- } \\
\text { Source Heat } \\
\text { Pumps } \\
\text { Overcoming } \\
\text { Market and } \\
\text { Technical } \\
\text { Barriers } \\
\text { Work Period: } \\
\text { September } \\
\text { 2004-Spring } \\
\text { 2006 }\end{array}$ & $\begin{array}{l}\text { Task 1: } \\
\text { Studying ideas } \\
\text { for improved } \\
\text { technical } \\
\text { performance and } \\
\text { cost of ground- } \\
\text { source heat } \\
\text { pump systems. } \\
\text { Task 2: } \\
\text { Identification of } \\
\text { economic/ } \\
\text { market barriers } \\
\text { and innovative } \\
\text { approaches to } \\
\text { increase system } \\
\text { acceptance } \\
\text { including } \\
\text { reduction of } \\
\text { initial } \\
\text { installation costs. }\end{array}$ & $\begin{array}{l}\text { Tasks address } \\
\text { technical issues } \\
\text { associated with } \\
\text { ground source } \\
\text { heat pump } \\
\text { technologies } \\
\text { including: } \\
\text {-Heating-only } \\
\text { vs. heating/ } \\
\text { cooling systems, } \\
\text {-Open versus } \\
\text { closed loop } \\
\text { systems, } \\
\text {-Horizontal } \\
\text { versus vertical } \\
\text { systems, } \\
\text {-Direct, } \\
\text { expansion and } \\
\text { secondary loop } \\
\text { systems, and } \\
\text {-Secondary } \\
\text { fluids (e.g.CO }{ }_{2} \text { ) }\end{array}$ & $\begin{array}{l}\text { 4.5.1 HVAC: } \\
\text {-Ground source } \\
\text { heat pump cost } \\
\text { reduction. } \\
\text {-Development } \\
\text { of lower-cost } \\
\text { methods of } \\
\text { trenching and } \\
\text { installation. }\end{array}$ \\
\hline
\end{tabular}




\begin{tabular}{|c|c|c|c|c|}
\hline $\begin{array}{l}\text { Implementing } \\
\text { Agreement }\end{array}$ & Annex & Selected Tasks & $\begin{array}{l}\text { Annex/Task } \\
\text { Descriptions }\end{array}$ & $\begin{array}{l}\text { Relevant BTP } \\
\text { Critical R\&D } \\
\text { Priority }\end{array}$ \\
\hline $\begin{array}{l}\text { Heat Pumping } \\
\text { Technologies, } \\
\text { continued }\end{array}$ & $\begin{array}{l}\text { Annex 31-- } \\
\text { Advanced } \\
\text { Modeling } \\
\text { and Tools } \\
\text { for } \\
\text { Analysis of } \\
\text { Energy } \\
\text { Use in } \\
\text { Super- } \\
\text { market } \\
\text { Systems } \\
\text { Work } \\
\text { Period: } \\
\text { January } \\
\text { 2006- } \\
\text { December } \\
2008\end{array}$ & $\begin{array}{l}\text { Task 1: Collection } \\
\text { of available data } \\
\text { from different } \\
\text { supermarkets } \\
\text { (benchmarking). } \\
\text { Task 4: } \\
\text { Development of } \\
\text { whole-building } \\
\text { simulation } \\
\text { models. } \\
\text { Task 5: } \\
\text { Comparison of the } \\
\text { results obtained } \\
\text { with the different } \\
\text { whole-building } \\
\text { simulation models } \\
\text { for selected case } \\
\text { studies. } \\
\text { Task 6: Future } \\
\text { perspectives and } \\
\text { possibilities. }\end{array}$ & $\begin{array}{l}\text { The aim of the } \\
\text { Annex is to } \\
\text { increase the level } \\
\text { of understanding } \\
\text { of the interaction } \\
\text { between the } \\
\text { refrigeration } \\
\text { system and the } \\
\text { indoor climate as } \\
\text { well as HVAC } \\
\text { system and the } \\
\text { building } \\
\text { envelope. The } \\
\text { aim will be } \\
\text { approached by } \\
\text { the development } \\
\text { of reasonably } \\
\text { accurate } \\
\text { simulation tools } \\
\text { that can be used } \\
\text { to assist in the } \\
\text { analysis of } \\
\text { energy } \\
\text { performance and } \\
\text { in the } \\
\text { development of } \\
\text { energy efficient } \\
\text { strategies for } \\
\text { supermarkets. }\end{array}$ & $\begin{array}{l}\text { 4.5.1 HVAC } \\
\text {-HVAC options } \\
\text { for the } \\
\text { commercial } \\
\text { zero-energy } \\
\text { building (ZEB), } \\
\text {-Improved } \\
\text { operational } \\
\text { procedures for } \\
\text { commercial } \\
\text { HVAC systems, } \\
\text {-Options and } \\
\text { impacts for pre- } \\
\text { cooling of } \\
\text { commercial } \\
\text { buildings, and } \\
\text {-Low energy } \\
\text { ventilation } \\
\text { strategies to } \\
\text { reduce energy } \\
\text { consumption in } \\
\text { commercial } \\
\text { buildings. }\end{array}$ \\
\hline
\end{tabular}




\begin{tabular}{|c|c|c|c|c|}
\hline $\begin{array}{l}\text { Implementing } \\
\text { Agreement }\end{array}$ & Annex & Selected Tasks & $\begin{array}{l}\text { Annex/Task } \\
\text { Descriptions }\end{array}$ & $\begin{array}{l}\text { Relevant BTP } \\
\text { Critical R\&D } \\
\text { Priority }\end{array}$ \\
\hline $\begin{array}{l}\text { Heat } \\
\text { Pumping } \\
\text { Technologies, } \\
\text { continued }\end{array}$ & $\begin{array}{l}\text { Annex } 32- \\
\text { Economical } \\
\text { Heating and } \\
\text { Cooling } \\
\text { Systems for } \\
\text { Low Energy } \\
\text { Houses } \\
\text { Work } \\
\text { Period: } \\
\text { January } \\
2006- \\
\text { December } \\
2008\end{array}$ & $\begin{array}{l}\text { Task 1: Market } \\
\text { and systems } \\
\text { survey including } \\
\text { analysis of } \\
\text { different } \\
\text { demand } \\
\text { structures such } \\
\text { as domestic hot } \\
\text { water, space } \\
\text { heating, cooling, } \\
\text { ventilation, and } \\
\text { de- } \\
\text { humidification. } \\
\text { Task 2: System } \\
\text { assessment and } \\
\text { comparison } \\
\text { including } \\
\text { analysis of } \\
\text { system controls. } \\
\text { Task 3: Field } \\
\text { testing of } \\
\text { integrated heat } \\
\text { pump systems. } \\
\text { Task } 4 \text { : System } \\
\text { assessment and } \\
\text { comparison. }\end{array}$ & $\begin{array}{l}\text { The objectives of } \\
\text { IEA HP Annex } \\
32 \text { are the further } \\
\text { development of } \\
\text { heat pumps for } \\
\text { the application in } \\
\text { low energy } \\
\text { houses. } \\
\text { A focus is on } \\
\text { multifunctional, } \\
\text { highly integrated } \\
\text { heat pump } \\
\text { systems. } \\
\text { Research is } \\
\text { mainly related to } \\
\text { the component } \\
\text { level, system } \\
\text { level and the } \\
\text { system design. }\end{array}$ & $\begin{array}{l}\text { 4.5 Critical R\&D } \\
\text { Programs: } \\
\text { - Integrated heat } \\
\text { pump systems, } \\
\text { and } \\
\text {-Standalone } \\
\text { direct expansion } \\
\text { dehumidification } \\
\text { systems with } \\
\text { energy recovery } \\
\text { ventilation. } \\
\text { 4.5.3 Appliances } \\
\text { Controls and } \\
\text { Miscellaneous } \\
\text { - Occupancy } \\
\text { sensors for } \\
\text { controlling } \\
\text { HVAC and other } \\
\text { loads, and } \\
\text {-Whole house } \\
\text { controls } \\
\text { integrating } \\
\text { appliance } \\
\text { operations. }\end{array}$ \\
\hline
\end{tabular}




\begin{tabular}{|c|c|c|c|c|}
\hline $\begin{array}{l}\text { Implementing } \\
\text { Agreement }\end{array}$ & Annex & Selected Tasks & $\begin{array}{l}\text { Annex/Task } \\
\text { Descriptions }\end{array}$ & $\begin{array}{l}\text { Relevant BTP } \\
\text { Critical R\&D } \\
\text { Priority }\end{array}$ \\
\hline & $\begin{array}{l}\text { Annex 33-- } \\
\text { Compact Heat } \\
\text { Exchangers in } \\
\text { Heat Pumping } \\
\text { Equipment } \\
\text { Work Period: } \\
\text { October } 2006 \text { - } \\
\text { September } 2009\end{array}$ & $\begin{array}{l}\text { Task 1: Market } \\
\text { research } \\
\text { Task 2: The } \\
\text { evaluation of } \\
\text { the performance } \\
\text { of compact heat } \\
\text { exchangers } \\
\text { relevant to heat } \\
\text { pumps. } \\
\text { Task 3: The } \\
\text { evaluation of } \\
\text { properties and } \\
\text { operating limits } \\
\text { of such } \\
\text { equipment. } \\
\text { Task 4: } \\
\text { Information } \\
\text { sharing. }\end{array}$ & $\begin{array}{l}\text { The principal } \\
\text { objective of this } \\
\text { annex is to } \\
\text { present a } \\
\text { compilation of } \\
\text { possible options } \\
\text { for compact heat } \\
\text { exchangers, } \\
\text { used as } \\
\text { evaporators, } \\
\text { condensers and } \\
\text { in other roles in } \\
\text { heat pumping } \\
\text { equipment. The } \\
\text { aim is to } \\
\text { minimize the } \\
\text { direct and } \\
\text { indirect effect } \\
\text { on the local and } \\
\text { global } \\
\text { environment due } \\
\text { to the operation } \\
\text { and disposal of } \\
\text { the equipment. }\end{array}$ & $\begin{array}{l}\text { 4.5 Critical } \\
R \& D \text { Priorities } \\
\text {-Large surface } \\
\text { heat } \\
\text { exchangers for } \\
\text { radiant floors, } \\
\text { walls, or } \\
\text { ceilings. }\end{array}$ \\
\hline
\end{tabular}




\begin{tabular}{|c|c|c|c|c|}
\hline $\begin{array}{l}\text { Imple- } \\
\text { menting } \\
\text { Agreement }\end{array}$ & Annex & Selected Tasks & $\begin{array}{l}\text { Annex/Task } \\
\text { Descriptions }\end{array}$ & $\begin{array}{l}\text { Relevant BTP } \\
\text { Critical R\&D } \\
\text { Priority }\end{array}$ \\
\hline & $\begin{array}{l}\text { Annex 34-- } \\
\text { Thermally } \\
\text { Driven } \\
\text { Heat } \\
\text { Pumps for } \\
\text { Heating } \\
\text { and } \\
\text { Cooling } \\
\text { Work } \\
\text { Period: } \\
\text { October } \\
\text { 2007 - } \\
\text { October } \\
2010\end{array}$ & $\begin{array}{l}\text { Task 1: Market } \\
\text { overview and } \\
\text { state of the art } \\
\text { including analysis } \\
\text { of thermally } \\
\text { driven heat pumps } \\
\text { in small and large } \\
\text { systems for } \\
\text { domestic } \\
\text { applications. } \\
\text { Task } 2 \text { : } \\
\text { Performance } \\
\text { evaluation, } \\
\text { development of } \\
\text { methodology for } \\
\text { determination of } \\
\text { coefficient of } \\
\text { performance and } \\
\text { life cycle cost } \\
\text { analysis. } \\
\text { Task } 3 \text { : } \\
\text { Apparatus } \\
\text { technology } \\
\text { development, } \\
\text { gathering of } \\
\text { components' } \\
\text { long-time running } \\
\text { performance and } \\
\text { database creation. } \\
\text { Task 4: System } \\
\text { technology, } \\
\text { including system } \\
\text { integration (e.g., } \\
\text { integration of heat } \\
\text { rejection, } \\
\text { air/ground- heat } \\
\text { sources) }\end{array}$ & $\begin{array}{l}\text { The goal of } \\
\text { Annex } 34 \text { is to } \\
\text { reduce the } \\
\text { environmental } \\
\text { impact of } \\
\text { heating } \\
\text { and cooling by } \\
\text { the use of } \\
\text { thermally driven } \\
\text { heat pumps. It } \\
\text { will be based } \\
\text { on the results } \\
\text { from Annex } 24 \text {, } \\
\text { "Absorption } \\
\text { Machines for } \\
\text { Heating and } \\
\text { Cooling in } \\
\text { Future Energy } \\
\text { Systems," and } \\
\text { cooperate with } \\
\text { the IEA-SHC } \\
\text { Task 38, "Solar } \\
\text { Air-conditioning } \\
\text { and } \\
\text { Refrigeration." }\end{array}$ & $\begin{array}{l}\text { 4.5 Critical R\&D } \\
\text { Priorities } \\
\text {-Integrated heat } \\
\text { pumps combining } \\
\text { heating, cooling, } \\
\text { ventilation, } \\
\text { humidity control, } \\
\text { and water heating. } \\
\text { 4.5.1 HVAC } \\
\text {-Ground source } \\
\text { heat pump } \\
\text { development/cost } \\
\text { reduction, } \\
\text {-Absorption heat } \\
\text { pumps, higher } \\
\text { efficiency boilers, } \\
\text { and radiant heating } \\
\text { systems, and } \\
\text {-Solar thermal } \\
\text { heating and } \\
\text { cooling (active and } \\
\text { passive). }\end{array}$ \\
\hline
\end{tabular}




\begin{tabular}{|c|c|c|c|c|}
\hline $\begin{array}{l}\text { Implementing } \\
\text { Agreement }\end{array}$ & Annex & $\begin{array}{l}\text { Selected } \\
\text { Tasks }\end{array}$ & $\begin{array}{l}\text { Annex/Task } \\
\text { Descriptions }\end{array}$ & $\begin{array}{l}\text { Relevant BTP } \\
\text { Critical R\&D } \\
\text { Priority }\end{array}$ \\
\hline \multirow[t]{2}{*}{$\begin{array}{l}\text { Energy } \\
\text { Conservation } \\
\text { in Buildings } \\
\text { and } \\
\text { Community } \\
\text { Systems }\end{array}$} & $\begin{array}{l}\text { Annex 5- } \\
\text { Air Infiltration } \\
\text { and } \\
\text { Ventilation } \\
\text { Centre } \\
\text { Work period: } \\
\text { Ongoing since } \\
1979\end{array}$ & $\begin{array}{l}\text { The Centre's } \\
\text { main role is to } \\
\text { disseminate } \\
\text { research } \\
\text { results } \\
\text { presented in } \\
\text { accessible and } \\
\text { informative } \\
\text { publications } \\
\text { and software. }\end{array}$ & $\begin{array}{l}\text { The Air } \\
\text { Infiltration and } \\
\text { Ventilation } \\
\text { Centre provides } \\
\text { technical } \\
\text { support in air } \\
\text { infiltration and } \\
\text { ventilation } \\
\text { research and } \\
\text { application. It } \\
\text { promotes } \\
\text { understanding of } \\
\text { the complex } \\
\text { behavior of } \\
\text { building air flow } \\
\text { and advances } \\
\text { the effective } \\
\text { application of } \\
\text { associated } \\
\text { energy saving } \\
\text { measures in both } \\
\text { the design of } \\
\text { new buildings } \\
\text { and the } \\
\text { improvement of } \\
\text { the existing } \\
\text { building stock. } \\
\end{array}$ & $\begin{array}{l}\text { HVAC } 4.5 .1 \\
\text {-Low energy } \\
\text { ventilation } \\
\text { strategies. }\end{array}$ \\
\hline & $\begin{array}{l}\text { Annex 47- } \\
\text { Cost Effective } \\
\text { Commissioning } \\
\text { of Existing and } \\
\text { Low Energy } \\
\text { Buildings }\end{array}$ & $\begin{array}{l}\text { Develop } \\
\text { methodologies } \\
\text { and tools to } \\
\text { improve } \\
\text { operation of } \\
\text { buildings in } \\
\text { use, including } \\
\text { identifying the } \\
\text { best energy } \\
\text { saving } \\
\text { opportunities } \\
\text { in HVAC } \\
\text { system } \\
\text { renovations. }\end{array}$ & $\begin{array}{l}\text { The goal of the } \\
\text { project is to } \\
\text { enable the } \\
\text { effective } \\
\text { commissioning } \\
\text { of existing and } \\
\text { future buildings } \\
\text { in order to } \\
\text { improve their } \\
\text { operating } \\
\text { performance. }\end{array}$ & $\begin{array}{l}\text { HVAC } 4.5 .1 \\
\text {-HVAC options } \\
\text { for commercial } \\
\text { ZEBs, and } \\
\text {-HVAC } \\
\text { solutions for } \\
\text { cold climates. } \\
\text { HVAC 4.5.3 } \\
\text {-Appliances, } \\
\text { Controls and } \\
\text { Miscellaneous. }\end{array}$ \\
\hline
\end{tabular}




\begin{tabular}{|c|c|c|c|c|}
\hline $\begin{array}{l}\text { Implementing } \\
\text { Agreement }\end{array}$ & Annex & Selected Tasks & $\begin{array}{l}\text { Annex/Task } \\
\text { Descriptions }\end{array}$ & $\begin{array}{l}\text { Relevant BTP } \\
\text { Critical R\&D } \\
\text { Priority }\end{array}$ \\
\hline & $\begin{array}{l}\text { Annex } 48 \text { - } \\
\text { Heat Pumping } \\
\text { and Reversible } \\
\text { Air } \\
\text { Conditioning } \\
\text { Work period: } \\
\text { 2005-2008 }\end{array}$ & $\begin{array}{l}\text { Subtask 1: } \\
\text { Analysis of } \\
\text { building } \\
\text { heating and } \\
\text { cooling } \\
\text { demands. } \\
\text { Subtask 2: } \\
\text { Performance } \\
\text { analysis and } \\
\text { comparison } \\
\text { among } \\
\text { components } \\
\text { and systems. }\end{array}$ & $\begin{array}{l}\text { The aim of this } \\
\text { project is to } \\
\text { promote the best } \\
\text { heat pumping } \\
\text { techniques } \\
\text { applicable in air } \\
\text { conditioning of } \\
\text { commercial } \\
\text { buildings. Focus } \\
\text { is given to the } \\
\text { integration of } \\
\text { these techniques } \\
\text { inside the whole } \\
\text { air conditioning } \\
\text { system. }\end{array}$ & $\begin{array}{l}\text { HVAC } 4.5 .1 \\
\text {-Ground source } \\
\text { heat pump cost } \\
\text { reduction, and } \\
\text {-Impacts and } \\
\text { options for pre- } \\
\text { cooling of } \\
\text { commercial } \\
\text { buildings. }\end{array}$ \\
\hline & $\begin{array}{l}\text { Annex 49- } \\
\text { Low Exergy } \\
\text { Systems for } \\
\text { High } \\
\text { Performance } \\
\text { Buildings and } \\
\text { Communities } \\
\text { Work period: } \\
\text { 2005-2009 }\end{array}$ & $\begin{array}{l}\text { Subtask A: } \\
\text { Methodologies. } \\
\text { Subtask B: } \\
\text { Exergy } \\
\text { efficient } \\
\text { community } \\
\text { supply } \\
\text { systems. } \\
\text { Subtask C: } \\
\text { Exergy } \\
\text { efficient } \\
\text { building } \\
\text { technologies. } \\
\text { Subtask D: } \\
\text { Knowledge } \\
\text { transfer, } \\
\text { dissemination. }\end{array}$ & $\begin{array}{l}\text { The main } \\
\text { objective of the } \\
\text { project is to use } \\
\text { exergy analysis as } \\
\text { a basis for } \\
\text { providing tools, } \\
\text { guidelines, } \\
\text { recommendations, } \\
\text { best-practice } \\
\text { examples and } \\
\text { background } \\
\text { material for } \\
\text { designers and } \\
\text { decision makers } \\
\text { in building, } \\
\text { energy production } \\
\text { and politics. }\end{array}$ & $\begin{array}{l}\text { HVAC } 4.5 .1 \\
\text {-Low exergy } \\
\text { heating and } \\
\text { cooling. }\end{array}$ \\
\hline
\end{tabular}




\subsubsection{Building Envelope MYPP}

The list below is organized according the areas of focus and tasks ${ }^{5}$ of the Envelope MYPP. Relevant IEA IA tasks are included beneath the MYPP task titles.

\section{o Advanced Attic and Roofing Systems}

Task 1. Integration of Phase Change Materials, Cool Colors, Above Sheathing Ventilation, Radiant Barrier and Advanced Lightweight Insulations

\section{ECBCS Annex 44:}

The annex will, based on the knowledge gained in the work so far (particularly the results of IEA Annexes 32, 35 and 37, SHC Task 23), address the following objectives:

- Define state-of-the-art of reactive building elements,

- Improve and optimize reactive building elements and technologies,

- Develop and optimize new building concepts with integration of reactive building elements, building services as well as natural and renewable energy strategies,

- Develop tools for the early assessment of the impact of reactive building elements on the environmental performance of buildings, and

- Develop guidelines for procedures and tools for detailed simulation of environmental performance of reactive building elements and integrated building concepts.

Of particular note are ECBCS, Annex 44a: Reactive Building Elements; and ECBCS, Annex 44b: Integration in Building Concepts.

This work by the ECBCS involves several studies, including work on phase change materials and dynamic insulation. The work summarizes the state of the art as developed in several countries, including Germany, Denmark, Austria, Italy, Norway, and New Zealand. See also http://www.aee-intec.at/0uploads/dateien323.pdf for a well-organized summary.

In addition, ECBCS Annex 43, jointly with the SHC Annex 34 has conducted a detailed study on double skin facades.

ECBCS, Annex 50: Prefabricated Systems for Low Energy Renovation of Residential Buildings includes work on prefabricated roof systems with integrated HVAC, hot water and solar systems. The United States is not participating in this annex because it focuses primarily on multi-story buildings, not single-family homes.

\footnotetext{
${ }^{5}$ A few areas of focus did not have specific tasks listed. Here, these smaller and unlabelled tasks are called "work areas."
} 
ECBCS, Annex 39: High Performance Thermal Insulation Systems (HiPTI) finished in 2004, but focused on compact, high-performance insulation. The United States did not participate in this annex.

\section{Task 2. Regionally Optimize Above-Sheathing Ventilation}

ECBCS, Annex 5: Air Infiltration and Ventilation Centre includes hundreds of studies over several decades. Some recent relevant work include "A Review of International Ventilation, Airtightness, Thermal Insulation and Indoor Air Quality Criteria," "Adaptive Thermal Comfort and Ventilation," "Parameters for the Design of Demand Controlled Hybrid Ventilation Systems for Residential Buildings," "Residential Ventilation," and "Residential Passive Ventilation Systems."

ECBCS, Annex 44 (work on advanced integrated facades).

Task 3. Best Practice for Integration of Phase Change Materials in Roof and Attic Assembly

ECBCS Annex 44 (see description under Task 1)

The annex will, based on the knowledge gained in the work so far (particularly the results of IEA Annexes 32, 35 and 37, SHC Task 23), address the following objectives:

- Define state-of-the-art of reactive building elements,

- Improve and optimize reactive building elements and technologies,

- Develop and optimize new building concepts with integration of reactive building elements, building services as well as natural and renewable energy strategies,

- Develop tools for the early assessment of the impact of reactive building elements on the environmental performance of buildings, and

- Develop guidelines for procedures and tools for detailed simulation of environmental performance of reactive building elements and integrated building concepts

Of particular note are ECBCS, Annex 44a: Reactive Building Elements; and ECBCS, Annex 44b: Integration in Building Concepts.

Task 4. Demonstration of Dynamically Active Roof and Attic

ECBCS Annex 44 (see description under Task 1).

\section{$\underline{\text { Task 5. Consolidation of Existing Energy Estimating Tools }}$}

ECBCS, Annex 43; and SHC, Annex 34: Testing and Validation of Building Energy Simulation Tools (BESTEST). 
ECBCS Annex 41 Whole Building Heat, Air and Moisture Response (MOIST-EN) on heat and moisture modeling (completed in 2007).

\section{o Advanced Wall Systems}

\section{Task 1. Whole-House Demonstration of Advanced Wall System}

ECBCS, Annex 44 (see description under Task 1, Advanced Attic and Roofing Systems).

ECBCS, Annex 50: Prefabricated Systems for Low Energy Renovation of Residential Buildings (including work on highly insulated envelopes with integrated new distribution systems for heating, cooling and ventilation). The U.S. is not participating in Annex 50.

SHC, Annex 37: Advanced Housing Renovation with Solar and Conservation.

\section{Task 2. Improved Wall Panel}

ECBCS Annexes 44 (see description under Task 1, Advanced Attic and Roofing Systems) and 50 (see description under Task 1).

SHC, Annex 37: Advanced Housing Renovation with Solar and Conservation.

\section{o Advanced Foundations}

Work area: Foundations Source Book with foundation details by climate, Zero-Energy Homes (ZEH) foundation type, and quality level.

ECBCS, Annex 43 and SHC, Annex 34: Testing and Validation of Building Energy Simulation Tools, specifically the subproject on "Ground-Coupled Heat Transfer with Respect to Floor Slab and Basement Construction."

\section{o Materials}

Work area 1: fibrous insulation manufactured to contain specially tailored phase change materials

Work area 2: climatically-tuned weather resistive membranes

Work area 3: changeable roof reflectivity

ECBCS, Annex 44 (see description under Task 1, Advanced Attic and Roofing Systems).

SHC, Annex 37: Advanced Housing Renovation with Solar and Conservation.

\section{o Enabling Technologies}

Task 1. Moisture Analysis

ECBCS, Annex 5: Air Infiltration and Ventilation Centre, including studies on moisture transfer.

ECBCS, Annex 41: Whole Building Heat, Air and Moisture Response (MOIST-EN). 


\section{$\underline{\text { Task 2. Moisture Material Properties }}$}

\section{Task 3. National/International Standards}

\section{Task 4. Facilitate Private Industrial Research}

[This task relates to a user center at ORNL, and hence does not focus on any single technology. This makes it hard to compare to specific implementing agreement research. However, private industry cooperates in many of the annexes and sub-annex projects sponsored by IEA IAs.] 


\subsubsection{Windows MYPP}

No IA annexes presently address window technologies in a concentrated way. There was an ECBCS annex (number 12) on windows from 1982-86, and SHC Annex 31 on daylighting (2001-2005), but no sustained and focused collaboration since then. There is substantial cutting-edge research going on in this area in Europe and Japan, suggesting that windows may present an excellent strategic opportunity for BTP to consider new collaboration, perhaps by proposing an annex covering areas of particular interest. The text below describes the work on windows currently underway in annexes, and includes references to cutting-edge international research in the Windows MYPP.

The SHC annex (Task 27) is conducting measurements and simulations of transparent façade components, which includes windows. Another annex in ECBCS (Annex 50) is concerned with special situations, such as low-energy, prefabricated assemblies for multifamily retrofits. ${ }^{6}$ Likewise, ECBCS Annex 44, "Integrating Environmentally Responsive Elements in Buildings," includes analysis of several advanced envelope components, including a small amount on windows. Several other projects in this annex examined windows several years ago but have now terminated those activities.

The MYPP identified numerous window technologies and research activities underway in Europe and Japan that are more advanced than in the United States. The table below lists references to those activities in three categories of the MYPP's Portfolio of Technical Pathways.

\footnotetext{
${ }^{6}$ The same Swiss laboratory—Empa—leads the research in both Annexes, so it is difficult to separate the activities.
} 
Table 3. Links between Windows MYPP and International R\&D

\begin{tabular}{|c|c|}
\hline $\begin{array}{c}\text { MYPP } \\
\text { Title }\end{array}$ & International Activities (from MYPP) \\
\hline $\begin{array}{l}\text { Highly } \\
\text { Insulated } \\
\text { Windows }\end{array}$ & $\begin{array}{l}\text { "...Powdered and granular aerogels that are diffusing are commercially } \\
\text { available in the U.S. and Europe and are used in low-volume, niche } \\
\text { applications...." } \\
\text { "... While the project team brings promising new technical approaches } \\
\text { to the challenge of hermetic seals, this effort in the US can best be } \\
\text { described as limited exploratory research since the investment required } \\
\text { to achieve a R10 commercialized product is far greater than what is } \\
\text { currently possible...." } \\
\text { "...The EU has recognized this and recently provided more than } \$ 10 \mathrm{M} \\
\text { for a research project to advance development of evacuated glazings..." } \\
\text { "... Because most high-R frames on the market today are designed and } \\
\text { manufactured in Europe, a large component of this task has been } \\
\text { subcontracted to Prof. Arild Gustavsen of the Norwegian University of } \\
\text { Science and Technology, with equal co-funding from the Norwegian } \\
\text { government and industry...." }\end{array}$ \\
\hline $\begin{array}{l}\text { Daylight } \\
\text { Redirecting }\end{array}$ & $\begin{array}{l}\text { "... The three-year EU Ecco-Build project and other EU projects have all } \\
\text { identified this area as promising and important and have invested heavily } \\
\text { in developing such intelligent systems...." }\end{array}$ \\
\hline $\begin{array}{l}\text { Enabling } \\
\text { Technology } \\
\text { Research } \\
\text { for } \\
\text { Efficient } \\
\text { Products }\end{array}$ & The International Glazing Database \\
\hline
\end{tabular}

The existence of these international activities suggests that greater U.S. participation could result in the net import of information and expertise (while achieving specific objectives listed in the MYPP). The IEA implementing agreement is one possible framework for collaboration. Since at least one bilateral agreement is already underway (with Norway), other approaches are also clearly possible. 


\subsubsection{Commercial Building Integration MYPP}

BTP has adopted a new approach to raise energy efficiency in the commercial building sector. The approach, described in the Commercial Building Integration (CBI) MYPP, will focus on testing, evaluating, and deploying technology with major commercial building owners and operators. BTP will target R\&D to support this process. This presents both opportunities and challenges with respect to the IEA IAs.

\section{o Opportunities}

Several IAs and other countries have experimented with the collaborative, technology procurement approach in moving technology into the market. Examining this international experience may provide useful insights for BTP and its commercial partners. Also, with the need for quick-response $\mathrm{R} \& \mathrm{D}$, looking at lessons learned from R\&D abroad may help speed the process of identifying innovative technology approaches. Regarding retail buildings and hotels (the first and fourth priorities of the MYPP), many of the companies that may participate in National Energy Alliances are international firms. Examples include McDonalds, Starbucks, Federal Express, and Marriott. These firms may have the ability to bring in additional international expertise on building energy efficiency based on their experience elsewhere. They may also see a benefit in applying state-of-the-art construction and operating procedures to their facilities worldwide.

\section{o Challenges}

The CBI MYPP focus on research as needed may make it difficult to collaborate on specific technologies through an IA. "One-time topical analyses" will probably operate on schedules incompatible with the longer time-scales required for IA technical collaboration. Likewise, the business sensitive nature of the collaboration on building design and energy use does not lend itself to international collaboration, although international collaboration may be helpful regarding organizational approaches and specific technology options.

\section{o Relevant Intersections}

Because so much of the specific technology R\&D will be selected on an annual basis, this mapping exercise is quite different from that of other MYPPs in this report. This section on relevant intersections looks at both the IA work on relevant organizational approaches (like bulk procurement) and the specific CBI research projects and priorities mentioned.

Several countries have worked with commercial building owners to improve energy efficiency. For example, Finland, France, Japan, and the Netherlands have created voluntary agreements and public-private partnerships to improve energy efficiency in commercial buildings. This work appears to include collaboration on design and commissioning issues, in some cases.

The DSM IA had an annex (Task 3) on Cooperative Procurement that helped shape the design of U.S. efforts on bulk procurement for efficient lighting. While this task is now closed, the countries who participated have continued their work in this area. It might be 
useful to revisit the contacts in this area to determine if future collaboration on procurement innovations would be beneficial. Likewise, the DSM agreement had a task on market transformation (Task 7), though most of the work under this task was focused on specific technologies, not whole buildings.

The on-going ECBCS Annex 46 on the Holistic Assessment Tool-kit on Energy Efficient Retrofit Measures for Government Buildings may also have applicable findings, since the work focuses on developing a package of cost-effective measures, somewhat like the "Technology Option Sets" described in the CBI MYPP. An important difference, though, is that Annex 46 focuses on retrofits instead of new designs.

The CBI MYPP describes the need for research in several specific areas both in support of collaboration with the private sector and for the first year of the MYPP. Three general areas of support stand out: preparation of guides, building decision tools, and commissioning. A large number of IAs have involved development of guides regarding design and implementation practices. These include annexes under ECBCS, DSM, HP and SHC. For example, the SHC Task 23 on Optimizing Solar Energy Use in Large Buildings included creation of an "Integrated Design Process Guide." In fact, guides summarizing best practice are one of the key outputs of end-use efficiency IAs. Regarding building decision tools, several IAs have worked in this areas, most notably through the development of BESTEST. BESTEST may be relevant in terms of ensuring that new software developed provides the most accurate results based on the technology innovations considered. Links under commissioning are described in the table below, which describes the CBI projects planned in the first year.

Table 4. Topical Links between CBI MYPP and Implementing Agreements

\begin{tabular}{|l|l|}
\hline CBI Project & IEA Implementing Agreement \\
\hline $\begin{array}{l}\text { Miscellaneous Electric } \\
\text { Loads }\end{array}$ & $\begin{array}{l}\text { 4E Annex 2, Standby Power; the DSM IA also has } \\
\text { several tasks that have examined electrical loads } \\
\text { including Task 11 on Time of Use Pricing }\end{array}$ \\
\hline Top lighting (skylights) & $\begin{array}{l}\text { ECBCS Annex 45, Energy Efficient Electric Lighting; 4E } \\
\text { planned new annex on lighting; ECBCS Annex 29 on } \\
\text { Daylight in Buildings (completed); SHC Task 31, } \\
\text { Daylighting Buildings in the 21st Century (completed) }\end{array}$ \\
\hline $\begin{array}{l}\text { Building Commissioning } \\
\text { (identified as a } \\
\text { responsibility of the } \\
\text { National Account) }\end{array}$ & $\begin{array}{l}\text { ECBCS Annex 47, Cost-Effective Commissioning for } \\
\text { Existing and Low Energy Buildings; ECBCS Annex 40, } \\
\text { Commissioning of Building HVAC Systems (completed) }\end{array}$ \\
\hline $\begin{array}{l}\text { National Accounts }- \\
\text { Supermarkets }\end{array}$ & $\begin{array}{l}\text { Heat Pump Annex 31, Advanced modeling and tools for } \\
\text { analysis in supermarket systems }\end{array}$ \\
\hline
\end{tabular}

BTP already participates in ECBCS Annex 47 (Commissioning), in Annex 31 (supermarkets) and in Annex 45 (lighting); BTP does not yet participate in the 4E.

Regarding technology areas selected for topical analysis in the future, ECBCS has several annexes that may prove relevant depending on the specific technologies considered. 
These include Annex 44 (Integrating Environmentally Responsive Elements in Buildings), Annex 5 (Air Infiltration and Ventilation Centre), and Annex 47 (Cost Effective Commissioning). The SHC and HP IAs also likely have relevant technology information. 


\subsubsection{Residential Integration MYPP}

BTP's Residential Integration Program focuses on improving the efficiency of new homes through research, development, demonstration, and improved technology integration. The IAs are not organized by commercial versus residential buildings, but several IAs cover residential energy efficiency technologies, and other technologies that can be applied in residential buildings. The most relevant IAs are ECBCS, SHC and HP. The table below describes how individual tasks in the Residential Integration MYPP link with existing and recent IA annexes.

Table 5. Map of Residential Integration MYPP and IEA Implementing Agreements

\begin{tabular}{|c|c|c|}
\hline Task & MYPP Task Title & Relevant IA Annex \\
\hline 1 & $\begin{array}{l}\text { Stage } 1-\mathrm{ZEH} \text { technology } \\
\text { pathways (This stage focuses } \\
\text { on using the BEopt analysis } \\
\text { tool to evaluate technology } \\
\text { pathways.) }\end{array}$ & $\begin{array}{l}\text { ECBCS Annex 44, Integrating Environmentally } \\
\text { Responsive Elements in Buildings (focuses on } \\
\text { optimizing building envelopes, HVAC and } \\
\text { other, and includes a subtask on design tools); } \\
\text { ECBCS Annex 41, Whole Building Heat, Air } \\
\text { and Moisture Response (includes modeling } \\
\text { principles and experimental investigations); } \\
\text { ECBCS Annex 43, Testing and Validation of } \\
\text { Building Energy Simulation Tools (being led by } \\
\text { the National Renewable Energy Laboratory, } \\
\text { which has also developed BEopt); 4E Annex on } \\
\text { Mapping and Benchmarking (focuses on } \\
\text { appliances). }\end{array}$ \\
\hline 2 & $\begin{array}{l}\text { Stage } 2-\text { System } \\
\text { performance evaluations } \\
\text { (This stage involves testing } \\
\text { of prototype subsystems to } \\
\text { determine the most reliable } \\
\text { and cost-effective solutions). }\end{array}$ & $\begin{array}{l}\text { Experience in other countries may be } \\
\text { particularly valuable here as some relevant } \\
\text { technologies may already be used or tested } \\
\text { abroad. IA annexes may highlight where this is } \\
\text { the case. Annexes of particular relevance } \\
\text { include ECBCS Annex 44, Integrating } \\
\text { Environmentally Responsive Elements in } \\
\text { Buildings; ECBCS Annex 45, Energy-Efficient } \\
\text { Future Electric Lighting for Buildings; ECBCS } \\
\text { Annex 48, Heat Pumping and Reversible Air } \\
\text { Conditioning; SHC Task 38, Solar Air- } \\
\text { Conditioning and Refrigeration; SHC Task 35, } \\
\text { PV/Thermal Systems; SHC Task 32, Advanced } \\
\text { Storage Concepts for Solar Thermal Systems in } \\
\text { Low Energy Buildings; HP Annex 32, } \\
\text { Economical Heating and Cooling Systems for } \\
\text { Low Energy Houses; HP Annex 34, Thermally } \\
\text { Driven Heat Pumps for Heating and Cooling; } \\
\text { 4E Annex on Mapping and Benchmarking. }\end{array}$ \\
\hline
\end{tabular}




\begin{tabular}{|c|c|c|}
\hline Task & MYPP Task Title & Relevant IA Annex \\
\hline $2-1$ & Self drying high- $\mathrm{R}$ walls & $\begin{array}{l}\text { ECBCS Annex 44, Integrating Environmentally } \\
\text { Responsive Elements in Buildings (includes } \\
\text { work on innovative wall technologies). }\end{array}$ \\
\hline $2-2$ & $\begin{array}{l}\text { Low loss hot water } \\
\text { distribution }\end{array}$ & $\begin{array}{l}\text { No current or recent annexes deal substantively } \\
\text { with hot water distribution within residential } \\
\text { buildings. However, the District Heating and } \\
\text { Cooling IA has done significant work over the } \\
\text { years on hot water distribution systems as part } \\
\text { of district heating networks. SHC Tasks } 38 \mathrm{~A} \\
\text { and } 35 \text { have looked at hot water piping for solar } \\
\text { systems. }\end{array}$ \\
\hline $2-3$ & $\begin{array}{l}\text { Low cost solar distributed } \\
\text { hot water }\end{array}$ & $\begin{array}{l}\text { SHC Task 35, PV/Solar, Thermal includes } \\
\text { analysis of hot water storage tanks and piping in } \\
\text { solar systems; SHC Task 38A, Pre-engineered } \\
\text { systems for residential and small commercial } \\
\text { applications. }\end{array}$ \\
\hline $2-4$ & $\begin{array}{l}\text { Miscellaneous electric loads } \\
(10-30 \% \text { savings })\end{array}$ & $\begin{array}{l}\text { 4E Annexes on Standby Power and Set-top } \\
\text { Boxes; possible future 4E Annex on Lighting. }\end{array}$ \\
\hline $2-5$ & $\begin{array}{l}\text { Air mixing from high } \\
\text { sidewall diffusers in cold } \\
\text { climates }\end{array}$ & $\begin{array}{l}\text { ECBCS Annex 5, Air Infiltration and } \\
\text { Ventilation Centre (has ongoing research on } \\
\text { compact ventilation for low-energy homes); } \\
\text { ECBCS Annex 41, Whole Building Heat, Air } \\
\text { and Moisture Response. }\end{array}$ \\
\hline $2-6$ & $\begin{array}{l}\text { Supplemental } \\
\text { dehumidification for hot } \\
\text { humid climates }\end{array}$ & $\begin{array}{l}\text { Most other IA members do not have hot, humid } \\
\text { climates, so there may be limited experience. } \\
\text { ECBCS Annex } 41 \text { does deal with moisture } \\
\text { response. }\end{array}$ \\
\hline $2-7$ & $\begin{array}{l}\text { Advanced, ultra efficient, } \\
\text { cost effective, low capacity } \\
\text { space conditioning systems }\end{array}$ & $\begin{array}{l}\text { ECBCS Annex 5, Air Infiltration and } \\
\text { Ventilation Centre; ECBCS Annex 48, Heat } \\
\text { Pumping and Reversible Air Conditioning; } \\
\text { ECBCS Annex 37, Low Exergy Systems for } \\
\text { Heating and Cooling (completed). }\end{array}$ \\
\hline $2-8$ & $\begin{array}{l}\text { Residential ventilation air } \\
\text { distribution study }\end{array}$ & $\begin{array}{l}\text { ECBCS Annex 5, Air Infiltration and } \\
\text { Ventilation Centre. }\end{array}$ \\
\hline $2-9$ & $\begin{array}{l}\text { Residential ventilation } \\
\text { strategies }\end{array}$ & $\begin{array}{l}\text { ECBCS Annex 5, Air Infiltration and } \\
\text { Ventilation Centre. }\end{array}$ \\
\hline $2-10$ & Ventilation system controller & $\begin{array}{l}\text { ECBCS Annex 5, Air Infiltration and } \\
\text { Ventilation Centre (has ongoing research on } \\
\text { ventilation system controllers). }\end{array}$ \\
\hline $2-11$ & $\begin{array}{l}\text { High coefficient performance } \\
\text { evaporative cooling system } \\
\text { evaluation }\end{array}$ & $\begin{array}{l}\text { ECBCS Annex 5, Air Infiltration and } \\
\text { Ventilation Centre; HP Annex 32, Economical } \\
\text { Heating and Cooling Systems for Low Energy } \\
\text { Houses; ECBCS Annex 37, Low Exergy } \\
\text { Systems for Heating and Cooling (completed). }\end{array}$ \\
\hline
\end{tabular}




\begin{tabular}{|c|l|l|}
\hline Task & \multicolumn{1}{|c|}{ MYPP Task Title } & \multicolumn{1}{c|}{ Relevant IA Annex } \\
\hline $2-13$ & $\begin{array}{l}\text { Advanced HVAC with } \\
\text { evaporatively cooled } \\
\text { condenser }\end{array}$ & $\begin{array}{l}\text { HP Annex 32, Economical Heating and Cooling } \\
\text { Systems for Low Energy Houses. }\end{array}$ \\
\hline $2-14$ & $\begin{array}{l}\text { Solar electric and thermal } \\
\text { (PV/T) }\end{array}$ & $\begin{array}{l}\text { SHC Task 35, PV/Thermal Solar Systems } \\
\text { (includes an overview of commercially } \\
\text { available products and the results of testing and } \\
\text { demonstrating systems). }\end{array}$ \\
\hline $2-15$ & $\begin{array}{l}\text { Accelerate development of } \\
\text { ZEH Program that promotes } \\
\text { use of residential PV systems }\end{array}$ & $\begin{array}{l}\text { SHC Task 35 PV/Thermal Solar Systems and } \\
\text { other SHC tasks. }\end{array}$ \\
\hline $2-16$ & $\begin{array}{l}\text { Develop high-R windows for } \\
\text { cold climates }\end{array}$ & $\begin{array}{l}\text { Windows are not a focus of existing annexes, } \\
\text { although ECBCS Annex 44 does include some } \\
\text { analysis of windows. Outside of IAs, there is } \\
\text { extensive research going on in this area in } \\
\text { Europe and Japan. }\end{array}$ \\
\hline 4 & $\begin{array}{l}\text { Stage 3- Prototype house } \\
\text { evaluations }\end{array}$ & $\begin{array}{l}\text { ECBCS Annex 47, Cost Effective } \\
\text { Commissioning of Existing and Low Energy } \\
\text { Buildings, is conducting research on how to } \\
\text { evaluate low-energy building performance. }\end{array}$ \\
\hline 5 & $\begin{array}{l}\text { Stage 4 - Initial community- } \\
\text { scale evaluations (Joule) }\end{array}$ & $\begin{array}{l}\text { ECBCS Annex 51, Energy Efficiency } \\
\text { Communities, has relevant information on } \\
\text { scaling up and evaluating community-level } \\
\text { efforts. ECBCS Annex 50, Prefabricated } \\
\text { Systems for Low Energy Renovation of } \\
\text { Residential Buildings, also has relevant } \\
\text { information on scaling up production, though it } \\
\text { is focused on retrofits particularly for multi- } \\
\text { family buildings. The United States is not } \\
\text { currently participating in either of these } \\
\text { annexes. The United States decided not to } \\
\text { participate in Annex 50 because most U.S. } \\
\text { residences are single-family homes, and few } \\
\text { annexes focus specifically on single-family } \\
\text { homes. This might be a strategic area to } \\
\text { consider in cooperation with other IA members } \\
\text { who have substantial stocks of single-family } \\
\text { homes (for example, Australia, Canada, and } \\
\text { Japan). }\end{array}$ \\
\hline in occupied homes
\end{tabular}


Table 6. Map of Analysis Tools MYPP and IEA Implementing Agreements

\begin{tabular}{|l|l|}
\hline Multi-Year Project Plan Activity & IEA Implementing Agreement \\
\hline Extend capabilities of analysis tools & ECBCS Annex 41, Whole Building Heat \\
Air and Moisture Response; ECBCS \\
Annex 42, The Simulation of Building- \\
Integrated Fuel Cell and Other \\
Cogeneration Systems; ECBCS Annex 44, \\
Integrating Environmentally Responsive \\
Elements in Buildings; SHC Annex 32, \\
Advanced Storage Concepts for Solar and \\
Low Energy Buildings; HP Annex 31-4, \\
Advanced Modeling and Tools for \\
Analysis of Energy Use in Supermarkets- \\
Development of whole-building simulation \\
models
\end{tabular}




\section{Conclusion}

DOE's longstanding participation in IEA IAs has been successful in many dimensions. As a core member of many IAs, DOE gained access to information, research and technology that would not have otherwise been available and that has proven valuable to U.S. industry, government, and other key constituencies. Its presence in IAs and related ExCos has also placed DOE in a position to assess and anticipate future research prospects and to exercise leadership by guiding the research agenda through new IAs and annexes. The interviews conducted in the course of this evaluation suggest that DOE's engagement in IEA IAs has elevated the prestige of the Department both in international science and technology circles and among U.S. firms participating in IAs and national teams.

BTP's involvement in IAs has been a major factor in overall success for DOE and U.S. industry. In the estimation of a wide range of U.S. participants, each of the four ongoing BTP-managed IAs assessed in this project is regarded as yielding significant value and benefits that make continued participation worthwhile. Similarly, several non-U.S. participants who were interviewed indicated that the long-term involvement of key BTP staff members and BTP-supported national laboratory staff members has been a source of continuity, stability, and expertise in the operation of these agreements and their ExCos. While BTP's participation in IAs is advantageous to DOE and U.S. industry, it appears to yield significant benefits to non-U.S. IA participants as well. Despite general agreement that these relationships are valuable to all participants, clear qualitative or quantitative metrics of value have not been established in the United States or elsewhere.

BTP could increase the value of its participation in IAs even further by articulating clear evaluation criteria and by adopting a more strategic approach. This would entail reviewing the portfolio of IAs periodically and aligning current and future activities with priorities specified in BTP's multi-year project plans and with other international activities in the EERE portfolio. Additional administrative measures within BTP, including more formalized information dissemination and more uniform and regular financial reporting, could help to provide the detail necessary for more thorough costbenefit analyses. 


\section{APPENDICES}




\section{Appendix A. Contact List: Officials with Responsibilities Relative to IEA Implementing Agreements in Energy End-Use}

This list provides basic contact information and brief summaries of roles of U.S. officials working with the IEA Secretariat or on Implementing Agreement Executive Committees. The list is divided into two sections. The first section lists staff who attend regular meetings at the IEA Secretariat. For these staff, both contact information and a brief description of their roles are included. The second section provides contact information for U.S. representatives, who are mainly from U.S. Department of Energy and national laboratories, serving on relevant IEA implementing agreement executive committees. The purpose of this contact list is to facilitate coordination between U.S. participants.

\section{Representatives to regular meetings at the IEA Secretariat:}

\section{U.S. Governing Board Representative}

Who: Dan Sullivan

Contact Info:

Assistant Secretary for Economic, Energy and Business Affairs

U.S. Department of State

Washington, D.C.

Tel: 202-647-7971

Who: Douglas Hengel

Contact Info:

Deputy Assistant Secretary of Energy, Sanctions and Commodities

U.S. Department of State

Washington, D.C.

Tel: 12026471498

Fax: 12026478758

HengelDC@state.gov

Role: The IEA Governing Board provides budgetary and programmatic oversight and control of the IEA Secretariat. It also reviews global energy issues, providing member countries with a chance to discuss these issues. The Governing Board approves the creation of new agreements and annexes and approves new members joining existing agreements.

\section{U.S. Ambassador to the Organisation for Economic Cooperation and Development (OECD)}

Who: Christopher F. Egan

Contact Info:

U.S. Delegation to the OECD

18, avenue Gabriel

75008 Paris, FRANCE

Tel: 33(0)1.45.24.7477

Fax: 33(0)1.45.24.7480

usoecdpao@usoecd.org 
Role $^{7}$ : The Ambassador communicates U.S. views and interests to other OECD Members and represents the United States in the Organization's governing body. He leads a team from four different federal agencies: U.S. Department of State, DOE, U.S. Agency for International Development, and the U.S. Department of Human and Health Services. The U.S. Mission to the OECD provides policy analysis and information to the U.S. Government based on the work of the OECD. Working with other Member countries, the U.S. Mission ensures the decisions taken by the OECD reflect the priorities of the U.S. Government. It also makes certain that the research done at the OECD is effectively disseminated and shared throughout respective U.S. Government departments and agencies, the public and other interested stakeholders.

Energy is one of priority work areas for U.S. Ambassador to the OECD. As Mr. Paul E. Simons, Deputy Assistant Secretary for Energy, Sanctions, and Commodities, stated in 2006, "In order to advance the policy objectives of diversification, efficiency, market pricing, technological development, and enhanced investment climates, the United States Government maintains a wide range of bilateral and multilateral engagements with energy producing, consuming and transiting countries. Chief among the multilateral fora is the International Energy Agency (IEA)."

\section{U.S. Energy Advisors Who: James McCracken \\ Contact Info: \\ Energy Adviser \\ United States Delegation to the OECD \\ Tel: 33145247451 \\ Fax: 33145247484 \\ mccrackenje@statea.gov \\ Who: Elizabeth Lisann \\ Contact Info: \\ Energy Adviser \\ United States Delegation to the OECD \\ Tel: 33145247459 \\ Fax: 33145247468 \\ lisanneg@usoecd.org}

Role: The U.S. energy advisors are based in Paris, France and coordinate closely with the IEA Secretariat. They attend most if not all of the IEA Committee meetings. They can be an excellent source of information on IEA Secretariat work and will usually be broadly familiar with the implementing agreements. They can pass messages to the Secretariat, and put DOE staff in touch with IEA staff working on specific issues of interest. They are also frequently in touch with delegates from other IEA member countries and, as such, may be able to help with contacts in other governments on specific issues. The United States usually has two energy advisors in Paris, one from DOE and one from State.

\footnotetext{
${ }^{7}$ http://www.usoecd.org/us-mission-oecd-role.html
} 


\section{U.S. Representative to the Committee on Energy Research and Technology (CERT) Who: Carmen Difiglio \\ Contact Info:}

Deputy Assistant Secretary for Policy Analysis

U.S. Department of Energy

Washington, DC

Tel: 202-586-8436

Fax: 202-586-0861

carmen.difiglio@hq.doe.gov

Role: CERT co-ordinates and promotes the development, demonstration, and deployment of technologies to meet challenges in the energy sector. It has established four expert bodies: the Working Party on Energy End-Use Technologies, the Working Party on Renewable Energy Technologies, the Working Party on Fossil Fuels, and the Fusion Power Coordinating Committee. In addition, expert groups have been established to advise on electric power technologies, R\&D priority setting and evaluation, and on oil and gas. The CERT oversees IEA's framework for more than 40 international collaborative energy research, development and demonstration projects known as Implementing Agreements.

\section{U.S. Representative to the End-Use Working Party Who: David Rodgers \\ Deputy Assistant Secretary for Energy Efficiency \\ Office of the Deputy Assistant Secretary for Technology Development \\ U.S. Department of Energy \\ Washington, D.C.}

Tel: 202-586-8038

Fax: 202-586-5163

david.rodgers@ee.doe.gov

Role: The End-Use Working Party is the central meeting place for the IEA's extensive international network for R\&D of technologies to increase the efficiency of energy end use. The network is comprised of 15 "implementing agreements" on individual technologies, for cooperative research, development, and demonstration in buildings, industry, transport, and electricity network technologies. The network has more than 150 contracting parties from more than 30 countries worldwide to guide the work. Under their leadership national experts collaborate on joint research projects. Outreach to industry and other experts involves thousands of leading global experts in research activities.

\section{U.S. Representative to the Standing Group on Long-term Co-operation (SLT) Who: Mr. Douglas Hengel \\ Contact Info:}

Deputy Assistant Secretary of Energy, Sanctions and Commodities

U.S. Department of State

Washington, D.C.

Tel: 12026471498

Fax: 12026478758

HengelDC@state.gov 
Who: Mr. Peter Haymond

Contact Info:

Chief, Energy and Natural Resources Division

Bureau of Economics, Energy and Business

U.S. Department of State.

Tel: 12026472871

Fax: 12026478758

haymondp@state.gov

Role: The SLT encourages cooperation among IEA member countries to ensure their collective energy security, improve energy efficiency, and promote environmental protection in the provision of energy services. The SLT also oversees the work of the IEA Secretariat's Office of Long-term Cooperation and Policy Analysis (LTO). The SLT established a separate expert body for energy efficiency: the Energy Efficiency Working Party. The SLT does not directly oversee the IAs.

\section{U.S. Representative to the Energy Efficiency Working Party Who: Mark Friedrichs}

Contact Info:

Office of Economic Analysis

U.S. Department of Energy

Tel: 202-586-0124

Fax: 202-586-3047

Mark.Friedrichs@hq.doe.gov

Role: This working party is under the SLT. It collates and reviews planned and existing energy efficiency programs in IEA member countries and investigates what is meant by energy conservation and the impact that energy conservation can have on overall economic activities. This working party does not oversee the IAs directly.

\section{Contacts relative to Specific Implementing Agreements}

\section{Members of Executive Committees of Buildings Related Agreements}

Heat Pump Agreement (http://www.heatpumpcentre.org )

Who: Antonio Bouza

Contact Info:

U.S. Department of Energy

1000 Independence Avenue, SW

Washington, DC 20585

Tel: 202-586-4563

Fax: 202-586-4617

Antonio.bouza@ee.doe.gov 
Solar Heating and Cooling Agreement (http://www.iea-shc.org/)

Who: Dru Crawley

Contact Info:

Office of the Building Technologies Program

U.S. Department of Energy

Washington, DC

Tel: 202-586-2344

Fax: 202-586-4617

drury.crawley@ee.doe.gov

Energy Conservation in Building and Community System, ECBCS

(http://www.ecbcs.org/)

Who: Rich Karney

Contact Info:

Office of Building Technologies Program

Mail Stop EE-2J

U.S. Department of Energy

1000 Independence Ave, SW

Washington DC 20585

Tel: +1 2025869449

Fax: +1 2025864617

richard.karney@ee.doe.gov

Energy Efficient Electrical Equipment (4E, http://www.iea-4e.org)

Who: Christopher Kent

Contact Info:

U.S. Environmental Protection Agency

kent.christopher@epa.gov

Who: Stephen L. Witkowski

Contact Info:

Office of the Building Technologies Program

U.S. Department of Energy

Washington, DC

Tel: 202-586-7463

stephen.witkowski@ee.doe.gov

Demand-Side Management, DSM (http://www.ieadsm.org/)

Who: Larry Mansueti

Contact Info:

Director, State and Regional Assistance

Office of Electricity Delivery and Energy Reliability

U.S. Department of Energy

1000 Independence Avenue SW

Washington DC 20585

Tel: +1 202-586-2588

lawrence.mansueti@hq.doe.gov 
District Heating and Cooling and CHP (http://www.iea-dhc.org/)

Who (main): Patricia W. Garland

Contact Info:

Engineering Science and Technology Division

Oak Ridge National Laboratory

901 One Bethel Valley Road

Oak Ridge, TN 37831-6070

Tel.: +1-(865)-574-2694

Fax: +1-(865)-574-9329

garlandpw@ornl.gov

Who (alternate): Mark Spurr

Contact Info:

FVB Energy Inc.

District Energy inc.

150 South Fifth Street, Suite 340

Minneapolis, MN 55402

Tel.: +1-612-607-4544

Fax: +1-612-338-3427

mspurr@fvbenergy.com

Who (alternative): Merrill Smith

Contact Info:

U.S. Department of Energy

1000 Independence Avenue SW

Washington DC 20585

Tel.: +1 2025863646

merrill.smith@hq.doe.gov

Energy Storage (http://www.iea-eces.org/)

Who: Imre Gyuk

Contact Info:

U.S. Department of Energy

1000 Independence Ave

Washington, DC 20585

Tel: 202-586-1482

Bus Fax: 202-586-0784

IMRE.GYUK@ee.doe.gov

Who (alternate): John Boyes

Contact:

Energy Storage Systems Program

Sandia National Laboratories

Mail Stop 0613

P.O. Box 5800

Albuquerque, NM, 87185

tel: +1-505-844-7090

fax:+1-505-844-6972

jdboyes@sandia.gov 


\section{Other End-Use Agreements}

Industrial Energy-Related Technologies and Systems (IETS) (http://www.iea-iets.org/) Who: James Quinn

Contact Info:

Office of the Industrial Technology Program

U.S. Department of Energy

Washington, DC

Tel: 202-586-5725

Fax: 202-586-9234

james.quinn@ee.doe.gov

Advanced Fuel Cells http://www.ieafuelcell.com

Who: Dr. Nancy Garland

Contact Info:

Office of Hydrogen, Fuel Cells and Infrastructure Technologies Program

U.S. Department of Energy

Washington, DC

Tel: 202-586-5673

Fax: 202-586-9811

Nancy.Garland@ee.doe.gov

Who (alternate) Dr. Wayne Surdoval

Contact Info:

National Energy Technology Laboratory

Tel: 1-412-386-6002

wayne.surdoval@netl.doe.gov

Advanced Materials for Transportation (http://www.iea-ia-amt.org/)

Who: Dr. Rogelio Sullivan

Contact Info:

Office of Vehicle Technology Program

U.S. Department of Energy

Tel: 202-586-8042

Fax: 202-586-1600

rogelio.sullivan@ee.doe.gov

Who: Dr. Stephen M. Hsu

Contact info:

George Washington University

stephen.hsu@erols.com 
Advanced Motor Fuels (http://www.iea-amf.vtt.fi/)

Who: Stephen Goguen

Contact Info:

Office of Vehicle Technology Program

U.S. Department of Energy

Washington, D.C. 20585

Tel: 202-586-8044

Fax: 202-586-1600

stephen.goguen@hq.doe.gov

Who (alternate): Kevin Stork

Contact info:

Office of Vehicle Technology Program

U.S. Department of Energy

Washington, D.C. 20585

Tel: 202-586-8306

Fax: 202-586-2476

kevin.stork@ee.doe.gov

Hybrid and Electric Vehicles http://www.ieahev.org/

Who: Tien Duong

Contact Info:

Office of Vehicle Technology Program

U.S. Department of Energy

Washington D.C.

Tel: 202-586-2210

Fax: 202-586-2476

tien.duong@ee.doe.gov

Who ( $1^{\text {st }}$ alternate): David Howell

Contact Info:

Office of Vehicle Technology Program

U.S. Department of Energy

Washington D.C.

Tel: 202-586-3148

Fax: 202-586-2476

david.howell@ee.doe.gov

Who ( $2^{\text {nd }}$ alternate): Barnes James

Contact Info:

Office of Vehicle Technology Program

U.S. Department of Energy

Washington D.C.

Tel: 202-586-5657

Fax: 202-586-1600

james.barnes@ee.doe.gov 
High-Temperature Super Conductivity (HTS) on the Electric Power Sector http://www.iea.org/tech/scond/scond.htm

Who: Debbie Haught

Contact Info:

Superconductivity Program Manager

Office of Electricity Delivery and Energy Reliability

Office of Utility Technologies

U.S. Department of Energy

Washington D.C. 20585-0121

Tel: 12025862211

Fax: 12025867114

debbie.haught@hq.doe.gov

Greenhouse Gas R\&D Programme (http://www.ieagreen.org.uk )

Who: Dr. Lowell Miller

Contact Info:

Office of Sequestration, Hydrogen and Clean Coal Fuels

FE-24 GTN, Room E-138

U.S. Department of Energy

1000 Independence Avenue, SW

Washington, DC 20585

Who (alternative): Dr. Jay Braitsch

Contact:

Office of Assistant Secretary for Fossil Energy

FE-24/Room 4G-067

U.S. Department of Energy

1000 Independence Avenue

Washington, DC 20585

Tel: 202-586-9682

Fax: 202-586-4729

Jay.Braitsch@hq.doe.gov

Climate Technology Initiative (CTI) (http://www.climatetech.net/ )

Who: Elmer C. Holt

Contact Info:

Economist

Office of Climate Change Policy and Technology

U.S. Department of Energy

Washington, DC

Tel: 202-586-0714

Fax: 202-586-0861

Elmer.Holt@hq.doe.gov 
Energy Technology Data Exchange (http://www.etde.org)

Who: Brian A. Hitson

Contact Info:

Associate Director, Administration and Information Services

Office of Scientific and Technical Information

U.S. Department of Energy

P.O. Box 62

Oak Ridge, Tennessee 37831

Tel: 18655761199

Fax: 18655763589

hitsonb@osti.gov

Who (alternate): Kelly Dunlap

Contact Info:

Team Leader, Administration and Information Services

Office of Scientific and Technical Information

U.S. Department of Energy

P.O. Box 62

Oak Ridge, Tennessee 37831

Tel: 18655761258

Fax: 18655763589

dunlapk@osti.gov

Energy Technology Systems Analysis Programme (ETSAP)

(http://www.etsap.org/index.asp)

Who ${ }^{8}$ : Carmen Difiglio

Contact Info:

Deputy Assistant Secretary for Policy Analysis

U.S. Department of Energy

Washington, DC

Tel: 202-586-8436

Fax: 202-586-0861

carmen.difiglio@hq.doe.gov

Who \& Contacts

John Lee (jcl@bnl.gov)

Tom Alfstad (Talfstad@bnl.gov ), Brookhaven National Laboratory

Joe DeCarolis (Decarolis.Joseph @epamail.epa.gov ), U.S. EPA

\footnotetext{
${ }^{8}$ http://www.etsap.org/Partner.asp.
} 


\section{Appendix B. Evaluation Interview Questionnaire}

The following questionnaire was used as a guide for interviews with a wide variety of participants in IEA IAs, including representatives of government, industry, and national laboratories in the United States and abroad. Since all questions were not relevant to all interviewees, the questionnaire was used principally to provide some structure to conversations with relevant individuals rather than as a more strictly observed survey instrument.

\section{Background}

* In which IAs were you involved? Annexes?

What were your role and how long were you involved in the IA?

\section{Process}

* What challenges did you encounter in forming the implementing agreement or annex?

* What other countries participated, and what were their roles in the IA?

- Did the IA framework facilitate effective collaboration?

\section{Outcomes}

* What technical, intellectual, or financial benefits resulted from U.S. participation in the IA, and to whom did these benefits accrue?

* Is it likely that these outcomes would have occurred had the U.S. worked alone or via a bilateral international agreement?

\section{Intellectual Property (IP), Commercialization and Technology Diffusion}

* Did collaboration through the IA lead to the development of new intellectual property (e.g., inventions, algorithms, designs, protocols)?

* Did ownership of intellectual property ever impede progress?

* Did the IA framework simplify IP problems?

* Did collaboration through the IA lead to or facilitate the commercialization of new technology?

* Did collaboration lead to or facilitate technology diffusion, expanding the use of a technology, or speeding its adoption (in your country)?

\section{Communication and Information Dissemination}

* What efforts did you make to disseminate results from your collaboration under this IA (e.g., personal discussions, presentations, newsletters, web publications, reports, briefings, journal articles, etc.)? Which of these did you find most effective?

* What was the intended audience for your outreach efforts (e.g., internal, academic, industry, government, other)?

* Can you identify examples where people outside the IA/annex used the results? 


\section{Goals}

* What were the goals of the IA or annex?

* Were these goals met? Why or why not?

* Were there any unforeseen accomplishments, such as identification of new research areas/questions, new programs, further collaborations, etc.?

\section{Funding}

* Was your participation in the IA sufficiently funded? 


\section{Appendix C. Recent Highlights of DOE-sponsored Participation in IEA IAs}

\begin{tabular}{|c|c|c|}
\hline $\begin{array}{l}\text { Implementing } \\
\text { Agreement }\end{array}$ & $\begin{array}{l}\text { Active Annexes (Tasks) w/ } \\
\text { U.S. Participation }\end{array}$ & $\begin{array}{l}\text { Highlights and Recent } \\
\text { Accomplishments }\end{array}$ \\
\hline HP & $\begin{array}{l}\text { - Ground-Source Heat Pumps } \\
\text { Overcoming Market and } \\
\text { Technical Barriers } \\
\text { - Advanced Modeling and } \\
\text { Tools for Analysis of } \\
\text { Energy Use in Supermarkets } \\
\text { - Economical Heating and } \\
\text { Cooling Systems for Low } \\
\text { Energy Houses } \\
\text { - Compact Heat Exchangers } \\
\text { in Heat Pumping Equipment }\end{array}$ & $\begin{array}{l}\text { Established the Heat Pump Centre } \\
\text { (Sweden) to disseminate } \\
\text { information on heat pump } \\
\text { technologies and promote IA } \\
\text { activities. } \\
\text { Results of annex on Test } \\
\text { Procedure and Seasonal } \\
\text { Performance Calculation for } \\
\text { Residential Heat Pumps were } \\
\text { adopted in } 2007 \text { as new EU } \\
\text { technology standards for } \\
\text { residential heat pumps. } \\
\text { U.S. National Team meets } 3-4 \\
\text { times annually to share } \\
\text { information, coordinate activities } \\
\text { and propose further collaboration. } \\
\text { U.S. Team is considered "the } \\
\text { model for national team } \\
\text { performance." } \\
4 \text { active annexes with } 11 \text { countries } \\
\text { participating. }\end{array}$ \\
\hline ECBCS & $\begin{array}{l}\text { - Air Infiltration and } \\
\text { Ventilation Centre } \\
\text { - Evaluation and } \\
\text { Demonstration of Domestic } \\
\text { Ventilation Systems } \\
\text { - Control Strategies for } \\
\text { Hybrid Ventilation in New } \\
\text { and Retrofitted Office } \\
\text { Buildings } \\
\text { - Retrofitting in Educational } \\
\text { Buildings - Energy Concept } \\
\text { Adviser for Technical } \\
\text { Retrofit Measures }\end{array}$ & $\begin{array}{l}\text { ECBCS administers the Future } \\
\text { Buildings Forum. In cooperation } \\
\text { with other buildings-related IAs, } \\
\text { the Forum organizes workshops } \\
\text { aimed at identifying long term } \\
\text { energy, environmental, economic } \\
\text { and technical issues related to } \\
\text { buildings and the R\&D needs } \\
\text { associated with them. } \\
\text { Material from annexes has } \\
\text { provided the basis for new } \\
\text { standards at state, national, and } \\
\text { international levels. } \\
\text { Established standards in several }\end{array}$ \\
\hline
\end{tabular}




\begin{tabular}{|c|c|c|}
\hline $\begin{array}{l}\text { Implementing } \\
\text { Agreement }\end{array}$ & $\begin{array}{l}\text { Active Annexes (Tasks) w/ } \\
\text { U.S. Participation }\end{array}$ & $\begin{array}{l}\text { Highlights and Recent } \\
\text { Accomplishments }\end{array}$ \\
\hline & $\begin{array}{l}\text { - Commissioning of Building } \\
\text { HVAC Systems for } \\
\text { Improving Energy } \\
\text { Performance } \\
\text { - Simulation of Building- } \\
\text { Integrated Fuel Cell and } \\
\text { Other Cogeneration Systems } \\
\text { - Energy-Efficient Future } \\
\text { Electric Lighting for } \\
\text { Buildings }\end{array}$ & $\begin{array}{l}\text { countries for application of design } \\
\text { instruments in ventilation and } \\
\text { cooling. } \\
\text { Established Information Centre for } \\
\text { Ventilation (Air Infiltration and } \\
\text { Ventilation Center or AIVC) to } \\
\text { disseminate information to } \\
\text { government and industry in } \\
\text { participating countries. } \\
8 \text { active annexes, with } 19 \text { countries } \\
\text { participating. } \\
\text { Budget of } € 665,000 \text { annually, } \\
\text { cost shared among participating } \\
\text { countries. }\end{array}$ \\
\hline SHC & $\begin{array}{l}\text { - Testing and Validation of } \\
\text { Building Energy Analysis } \\
\text { Tools } \\
\text { - Solar Resource Knowledge } \\
\text { Management }\end{array}$ & $\begin{array}{l}\text { Standardizes and benchmarks } \\
\text { international solar resource data } \\
\text { sets to ensure worldwide } \\
\text { intercomparability and acceptance. } \\
\text { Develops methods that improve } \\
\text { the quality and the spatial and } \\
\text { temporal coverage, with } \\
\text { customized solar resource } \\
\text { products, including reliable solar } \\
\text { radiation forecasts. } \\
\text { ANSI/ASHRAE Standard } 140 \\
\text { codified the original IEA Building } \\
\text { Energy Simulation Test } \\
\text { (BESTEST) as a standard method } \\
\text { of test for software, and the } \\
\text { European Committee for } \\
\text { Standardization used BESTEST to } \\
\text { check their reference cooling load } \\
\text { and cooling energy calculation } \\
\text { methods. } \\
8 \text { active annexes with } 18 \text { countries } \\
\text { participating. }\end{array}$ \\
\hline
\end{tabular}




\begin{tabular}{|c|c|c|}
\hline $\begin{array}{l}\text { Implementing } \\
\text { Agreement }\end{array}$ & $\begin{array}{l}\text { Active Annexes (Tasks) w/ } \\
\text { U.S. Participation }\end{array}$ & $\begin{array}{l}\text { Highlights and Recent } \\
\text { Accomplishments }\end{array}$ \\
\hline DSM & $\begin{array}{l}\text { - Cooperation on Energy } \\
\text { Standards } \\
\text { - Competitive Energy } \\
\text { Services } \\
\text { - Network Driven DSM } \\
\text { - DSM and Climate Change } \\
\text { - Time of Use Pricing and } \\
\text { Energy Use for DSM } \\
\text { - Integration of DSM, } \\
\text { Energy Efficiency, } \\
\text { Distributed Generation and } \\
\text { Renewable Energy Sources }\end{array}$ & $\begin{array}{l}\text { Created INDEEP, a } \\
\text { comprehensive international web- } \\
\text { based database in four languages, } \\
\text { describing over } 220 \text { utility DSM } \\
\text { programs in } 15 \text { countries. } \\
\text { Compiled case studies of "best } \\
\text { practices" to serve as models for } \\
\text { municipalities to effectively } \\
\text { implement energy efficiency } \\
\text { measures in a liberalized market. } \\
\text { Defined a variety of innovative } \\
\text { energy-related services to } \\
\text { implement through cost-effective } \\
\text { communication technologies to } \\
\text { help Energy Service } \\
\text { Companies (ESCOs) provide } \\
\text { better services at lower costs. Such } \\
\text { services include load control, data } \\
\text { transmission, automated meter } \\
\text { reading and billing. } \\
\text { Produced "A Practical Guide to } \\
\text { Demand Side Bidding (DSB)" } \\
\text { which provides practical } \\
\text { guidelines for the electricity } \\
\text { industry and customers on the } \\
\text { rules for DSB. } \\
6 \text { active Tasks, with } 19 \\
\text { participating countries. } \\
\text { Budget of } ~ \$ 460,000 \text { annually, } \\
\text { cost shared among participating } \\
\text { countries. }\end{array}$ \\
\hline $4 E$ & $\begin{array}{l}\text { - Currently in formation } \\
\text { process }\end{array}$ & \\
\hline
\end{tabular}




\section{Appendix D. List of Active IEA IAs}

The U.S. participates in 38 of the 42 IAs that are now active (U.S. participation marked with an asterisk below). Of the 42 agreements, 7 have direct relevance for buildings (ECBCS, HP, SHC, DSM, 4E, Energy Storage, and District Heating and Cooling). Six other agreements address end-use energy efficiency in industry and transport, and 9 additional agreements focus on renewable energy technologies.

(In formation:) Efficient Electrical End-Use Equipment*

Advanced Fuel Cells*

Advanced Materials for Transportation*

Advanced Motor Fuels*

ASDEX-Upgrade*

Bioenergy*

Energy Conservation in Buildings and Community Systems (ECBCS)*

Clean Coal Sciences*

Climate Technology Initiative (CTI)*

Demand-Side Management*

District Heating and Cooling*

Electricity Networks Analysis, Research \& Development (ENARD)

Emissions Reduction in Combustion*

Energy Storage*

Energy Technology Data Exchange (ETDE)*

Energy Technology Systems Analysis Programme (ETSAP)*

Enhanced Oil Recovery*

Environmental, Safety and Economic Aspects of Fusion Power*

Fluidized Bed Conversion

Fusion Materials*

Geothermal*

Greenhouse Gas RD Programme*

Heat Pumping Technologies*

High-Temperature Superconductivity (HTS) on the Electric Power Sector*

Hybrid and Electric Vehicles*

Hydrogen*

Hydropower

IEA Clean Coal Centre*

Industrial Energy-Related Technologies and Systems* 


\author{
Large Tokamaks* \\ Multiphase Flow Sciences* \\ Nuclear Technology of Fusion Reactors* \\ Ocean Energy Systems* \\ Photovoltaic Power Systems* \\ Plasma Wall Interaction in TEXTOR* \\ Renewable Energy Technology Deployment \\ Reversed Field Pinches* \\ Solar Heating and Cooling* \\ SolarPACES* \\ Spherical Tori* \\ Stellarator Concept* \\ Wind Energy Systems*
}




\section{Appendix E. MYPP-IA Matrix Spreadsheet ${ }^{\underline{9}}$}

This matrix summarizes the relevant intersections found between the MYPPs and IA annexes during the mapping exercise.

\footnotetext{
${ }^{9}$ See next page for the text of this appendix.
} 


\begin{tabular}{|c|c|c|c|c|c|c|c|c|c|c|c|c|c|c|c|c|c|c|c|c|c|c|c|c|c|c|}
\hline & & & & \multicolumn{23}{|c|}{ BTP MYPPs } \\
\hline & & & & \multicolumn{3}{|c|}{ HVAC } & \multicolumn{5}{|c|}{ Building Envelopes } & \multicolumn{3}{|c|}{ Windows } & \multicolumn{4}{|c|}{$\begin{array}{l}\text { Commercial } \\
\text { Buildings } \\
\text { Integration }\end{array}$} & \multicolumn{5}{|c|}{$\begin{array}{l}\text { Residential } \\
\text { Integration }\end{array}$} & \multicolumn{3}{|c|}{$\begin{array}{l}\text { Analysis } \\
\text { Tools }\end{array}$} \\
\hline IA & 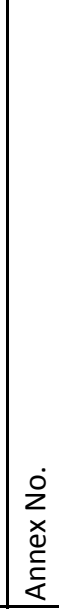 & Current Annexes & 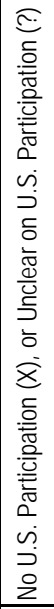 & 岀 & 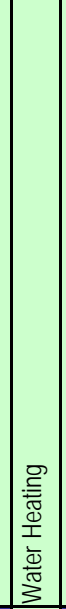 & 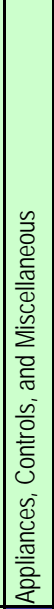 & 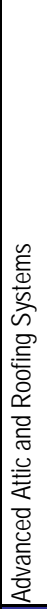 & 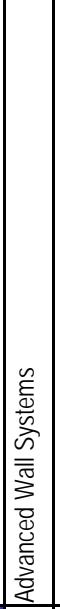 & 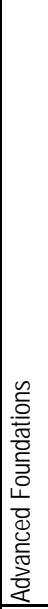 & 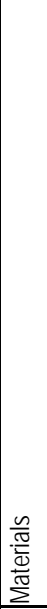 & 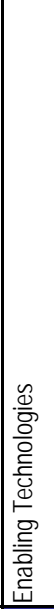 & 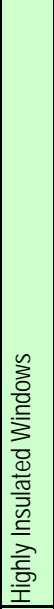 & 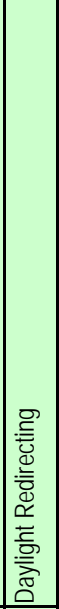 & 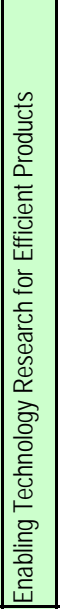 & 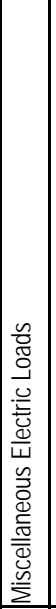 & 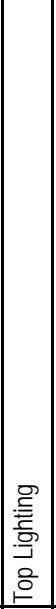 & 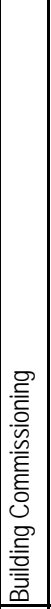 & 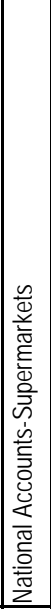 & 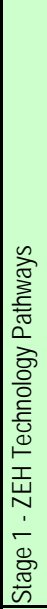 & 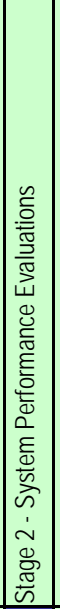 & 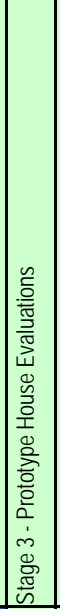 & 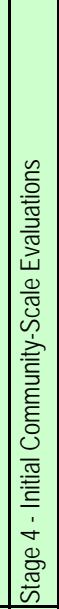 & 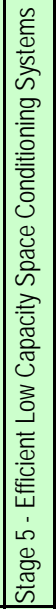 & 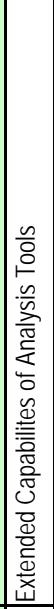 & 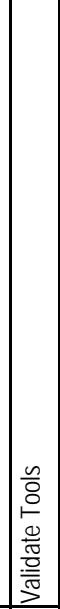 & 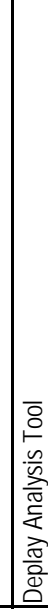 \\
\hline ECBCS & 5 & Air Infiltration and Ventilation Centre & & & & & & & & & & & & & & & & & & & & & & & & \\
\hline ECBCS & 41 & Whole Building Heat Air and Moisture Response (MOIST-EN) & & & & & & & & & & & & & & & & & & & & & & & & \\
\hline ECBCS & $41 a$ & Modelling and common exercises & & & & & & & & & & & & & & & & & & & & & & & & \\
\hline ECBCS & $41 b$ & Experimental investigation & & & & & & & & & & & & & & & & & & & & & & & & \\
\hline ECBCS & $41 c$ & Boundary conditions & & & & & & & & & & & & & & & & & & & & & & & & \\
\hline ECBCS & $41 d$ & Long term performance and technology transfer & & & & & & & & & & & & & & & & & & & & & & & & \\
\hline ECBCS & 42 & Simulation of Building-Integrated Fuel Cell and Other Cogeneration Systems (COGEN-SIM) & & & & & & & & & & & & & & & & & & & & & & & & \\
\hline ECBCS & $42 a$ & Characterization of cogeneration systems and occupant-driven electrical and domestic hot water usage patterns & & & & & & & & & & & & & & & & & & & & & & & & \\
\hline ECBCS & $42 b$ & Development, implementation and validation of cogeneration system models in building simulation programs & & & & & & & & & & & & & & & & & & & & & & & & \\
\hline ECBCS & $42 c$ & Technical, environmental and economic assessment of selected cogeneration applications & & & & & & & & & & & & & & & & & & & & & & & & \\
\hline ECBCS & 43 & Testing and Validation of Building Energy Simulation Tools & & & & & & & & & & & & & & & & & & & & & & & & \\
\hline ECBCS & $43 a$ & Comparative tests & & & & & & & & & & & & & & & & & & & & & & & & \\
\hline ECBCS & $43 b$ & Subtasks empirical validation & & & & & & & & & & & & & & & & & & & & & & & & \\
\hline ECBCS & 44 & Integrating Environmentally Responsive Elements in Buildings & & & & & & & & & & & & & & & & & & & & & & & & \\
\hline ECBCS & $44 a$ & Reactive building elements & & & & & & & & & & & & & & & & & & & & & & & & \\
\hline ECBCS & $44 b$ & Integration in building concepts & & & & & & & & & & & & & & & & & & & & & & & & \\
\hline ECBCS & $44 c$ & Design tools and Environments Performance Assessment & & & & & & & & & & & & & & & & & & & & & & & & \\
\hline ECBCS & $44 d$ & Implementation & & & & & & & & & & & & & & & & & & & & & & & & \\
\hline ECBCS & 45 & Energy Efficient Electric Lighting for Buildings & & & & & & & & & & & & & & & & & & & & & & & & \\
\hline ECBCS & $45 a$ & Targets for energy performance and human well-being & & & & & & & & & & & & & & & & & & & & & & & & \\
\hline ECBCS & $45 b$ & Innovative technical solutions & & & & & & & & & & & & & & & & & & & & & & & & \\
\hline ECBCS & $45 c$ & Energy-efficient controls and integration & & & & & & & & & & & & & & & & & & & & & & & & \\
\hline ECBCS & $45 d$ & Information dissemination & & & & & & & & & & & & & & & & & & & & & & & & \\
\hline ECBCS & 46 & Holistic Assessment Toolkit on Energy Efficient Retrofit Measures for Government Buildings & & & & & & & & & & & & & & & & & & & & & & & & \\
\hline ECBCS & $46 a$ & Develop an energy assessment and analysis methodology/protocol and Energy Assessment Guide & & & & & & & & & & & & & & & & & & & & & & & & \\
\hline ECBCS & $46 b$ & Develop a database of "Energy Saving Technologies and Measures for Government Building Retrofits" & & & & & & & & & & & & & & & & & & & & & & & & \\
\hline ECBCS & $46 c$ & Develop "Best Practice Guidelines for Innovative Energy Performance Contracts" & & & & & & & & & & & & & & & & & & & & & & & & \\
\hline ECBCS & $46 d$ & Develop IT-toolkit "EnERGo" & & & & & & & & & & & & & & & & & & & & & & & & \\
\hline
\end{tabular}




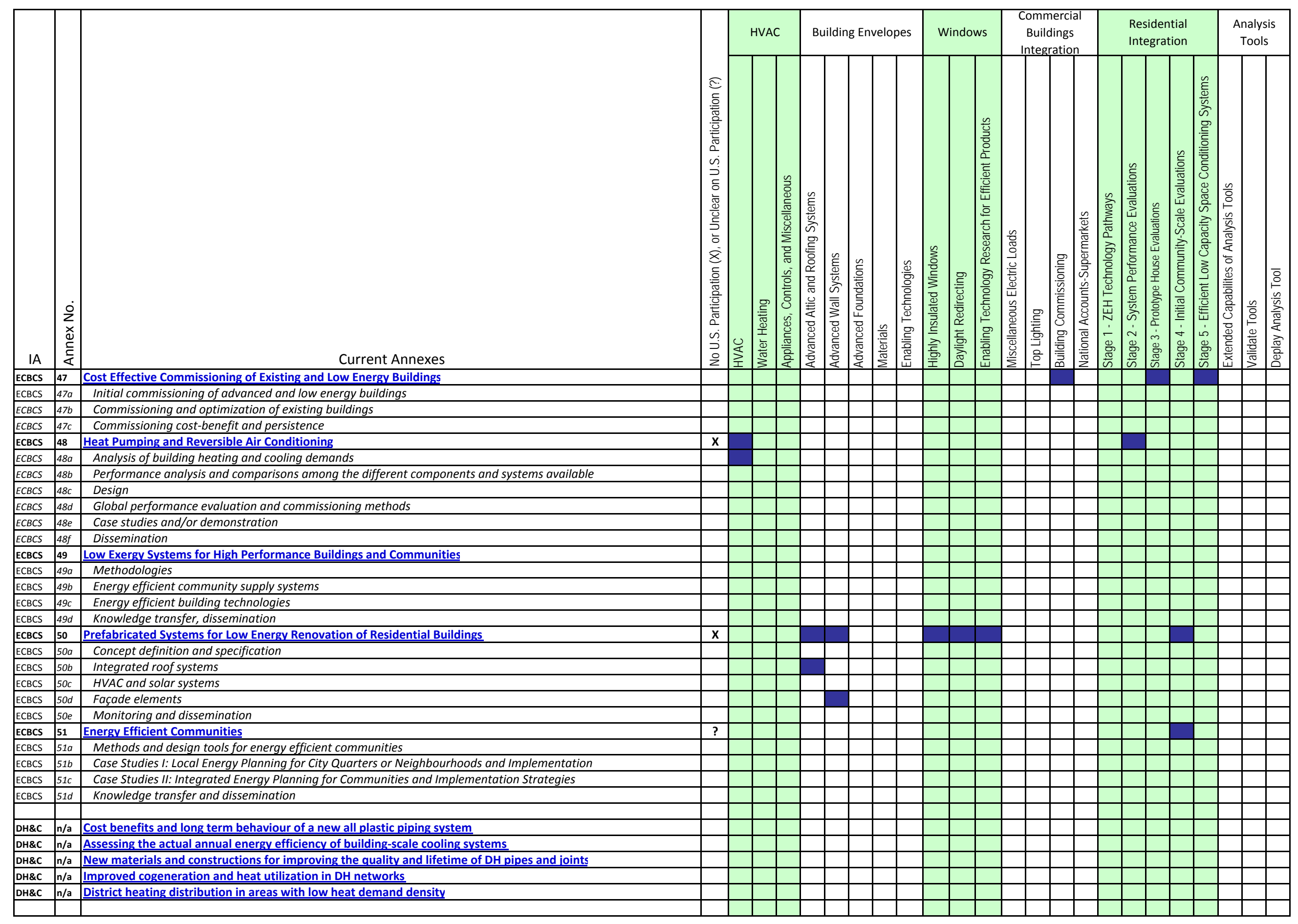




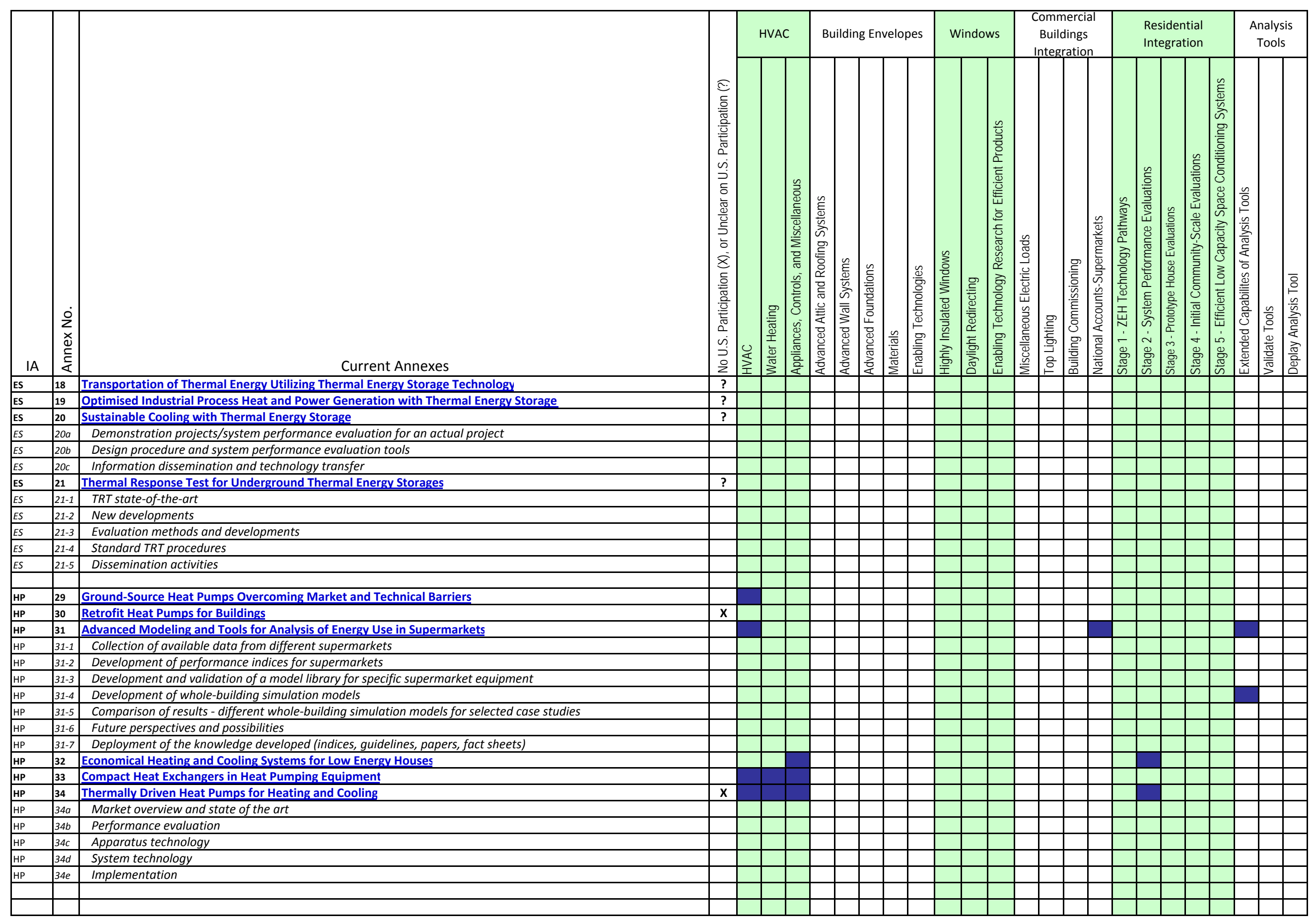




\begin{tabular}{|c|c|c|c|c|c|c|c|c|c|c|c|c|c|c|c|c|c|c|c|c|}
\hline \multirow[b]{2}{*}{$\mid A$} & \multirow[b]{2}{*}{ 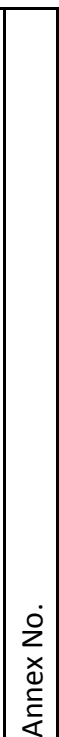 } & \multirow[b]{2}{*}{ 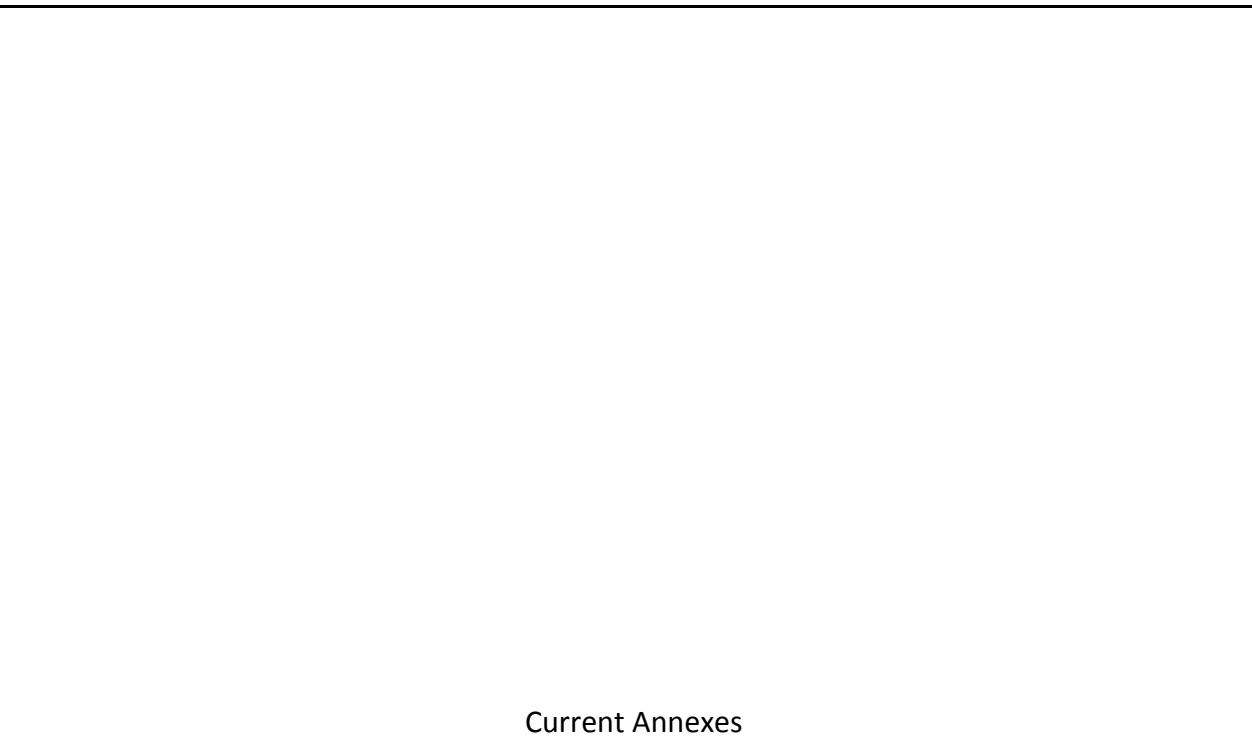 } & \multirow[b]{2}{*}{ 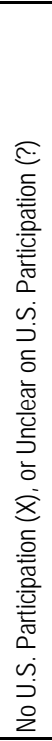 } & \multicolumn{2}{|c|}{ HVAC } & \multicolumn{4}{|c|}{ Building Envelopes } & \multicolumn{2}{|c|}{ Windows } & \multicolumn{3}{|c|}{$\begin{array}{c}\text { Commercial } \\
\text { Buildings } \\
\text { Integration }\end{array}$} & \multicolumn{3}{|c|}{$\begin{array}{l}\text { Residential } \\
\text { Integration }\end{array}$} & \multicolumn{3}{|c|}{$\begin{array}{c}\text { Analysis } \\
\text { Tools }\end{array}$} \\
\hline & & & & & 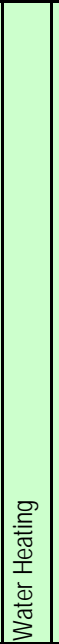 & \multirow[t]{2}{*}{ 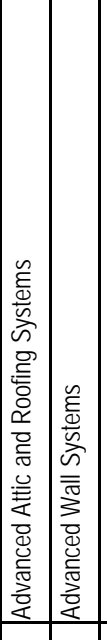 } & 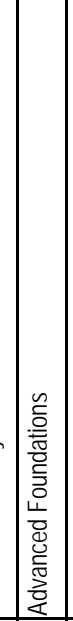 & & 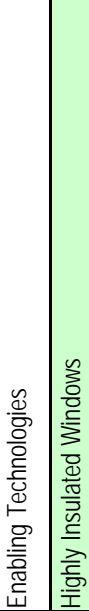 & 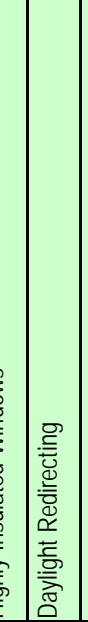 & 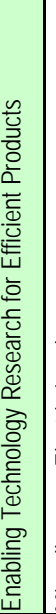 & 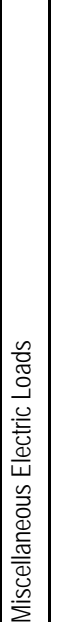 & & 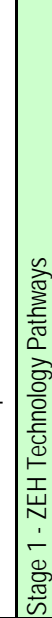 & 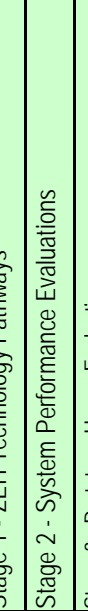 & 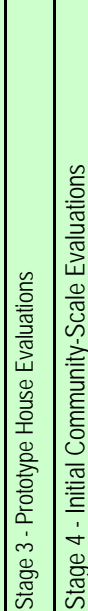 & 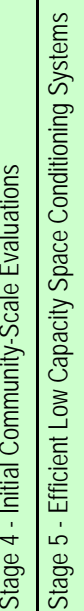 & 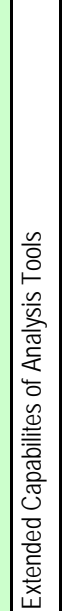 & & 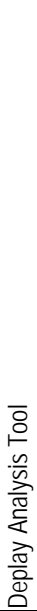 \\
\hline SHC & 32 & Advanced storage concepts for solar and low energy buildings & & & & & & & & & & & & & & & & & & \\
\hline SHC & 33 & Solar heat for industrial process & & & & & 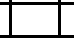 & & & & 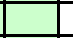 & & & & & 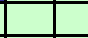 & & & & \\
\hline SHC & 34 & Testing and validation of building energy simulation tools & & & & & & & & & & & & & & & & & & \\
\hline SHC & 35 & $\mathrm{PV} /$ thermal systems & & & & & & & & & & & & & & & & & & \\
\hline SHC & 36 & Solar resource knowledge management & $?$ & & & & & & & & & & & & & & & & & \\
\hline SHC & 37 & Advanced housing renovation with solar and conservation & & & & & & & & & & & & & & & & & & \\
\hline SHC & 38 & Solar air conditioning and refrigeration & & & & & & & & & & & & & & & & & & \\
\hline SHC & 39 & Polymeric materials for solar thermal applications & & & & & & & & & & & & & & & & & & \\
\hline & 4 & & & & & & & & & & & & & & & & & & & \\
\hline & & & & & & & & & & & & & & & & & & & & \\
\hline DSM & 11 & Energy use, metering and pricing for demand management delivery & $\mathbf{x}$ & & & & & & & & & & & & & & & & & \\
\hline DSM & 12 & Co-operation on energy standards & $\mathbf{x}$ & & & & & & & & & & & & & & & & & \\
\hline DSM & 15 & Network driven DSM & & & & & & & & & & & & & & & & & & \\
\hline DSM & 16 & Competititve energy services & $\mathbf{x}$ & & & & & & & & & & & & 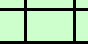 & 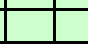 & & & 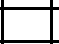 & \\
\hline DSM & 17 & Integration of Demand Side Management, energy efficiency, distributed generation and renewable energy sources & & & & & & & & & & & & & & & & & & \\
\hline DSM & 18 & Demand Side Management and Climate Change & & & & & & & & & & & & & & & & & & \\
\hline & & & & & & & & & & & & & & & & & & & & \\
\hline $4 \mathrm{E}$ & 1 & Mapping and benchmarking & & & & & & & & & & & & & & & & & & \\
\hline $4 \mathrm{E}$ & 2 & Standby power & & & & & & & & & & & & & & 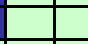 & & & & \\
\hline $4 \mathrm{E}$ & 3 & Set-top boxes & & & & & & & & & & & & & & & & & & \\
\hline $4 \mathrm{E}$ & 4 & Motor systems & & & & & & & & & & & & & & & & & & \\
\hline $4 \mathrm{E}$ & 5 & Lighting & & & & & & & & & & & & & & & & & & \\
\hline $4 E$ & 6 & Supply chain agreements & & & & & & & & & & & & & & & & & & \\
\hline $4 \mathrm{E}$ & 7 & Energy efficient product/service systems & & & & & & & & & & & & & & & & & & \\
\hline
\end{tabular}




\section{Appendix F. Table of U.S. Participation in IEA IAs ${ }^{10}$}

This table describes in a summary fashion which U.S. institutions participate in each of the 5 end-use IAs studied during this evaluation.

${ }^{10}$ See next page for the text of this appendix. 
ECBCS 41 Whole Building Heat Air and Moisture Response (MOIST-EN

ECBCS 41 Modelling and common exercises

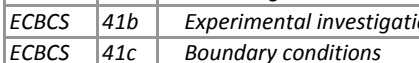

\begin{tabular}{|llll} 
ECBCS & $41 c$ & Boundary conditions \\
\hline ECBCS & $41 d$ & Long term performance and technology transfer
\end{tabular}

ECBCS 42 Simulation of Building-Integrated Fuel Cell and Other Cogeneration Systems (COGEN-SIM)

ECBCS $42 a \quad$ Characterization of cogeneration systems and occupant-driven electrical and domestic hot water usage patterns

\begin{tabular}{llll}
$E C B C S$ & $42 b$ & Development, implementation and validation of cogeneration system models in builiting $S$ Wim \\
\hline ECBCS & $42 c$ & Technical, environmental and economic assessment of selected cogeneration applications
\end{tabular}

ECBCS 43 Testing and Validation of Building Energy Simulation Tools

ECBCS 43 Comparative tests

ECBCS 436 Subtasks empirical validation

ECBCS 44 Integrating Environmentally Responsive Elements in Buildings

CBCS $44 a$ Reactive building elements

(t) The

ECBCS 444 Design tools and 44 Implementation

ECBCS 45 Energy Efficient Electric Lighting for Buildings

ECBCS $45 a \quad$ Targets for energy performance and human well-being

ECBCS $456 \quad$ Innovative technical solutions

ECBCS $45 \mathrm{C}$ Energy-efficient controls and integration

CBCS $45 d$ Information dissemination

ECBCS $46 \quad$ Holistic Assessment Toolkit on Energy Efficient Retrofit Measures for Government Buildings

ECBCS 46 Develop an energy assessment and analysis methodology/protocol and Energy Assessment Guild

\begin{tabular}{ll|l}
\hline ECBCS & $46 c$ & Develop "Best Practice Guidelines for Innovative Energy Performance Contracts"
\end{tabular}

ECBCS $46 d$ Develop IT-toolkit "EnERGo"

ECBCS 47 Cost Effective Commissioning of Existing and Low Energy Buildings

ECBCS 470 Initial commissioning of advanced and low energy buildings

$\begin{array}{llll}\text { ECBCS } & 476 & \text { Commissioning and optimization of existing buildings }\end{array}$

\begin{tabular}{llll} 
ECBCS & $47 \mathrm{C}$ & Commissioning cost-benefit and persistence \\
\hline ECBCS & 48 & Heat Pumping and Reversible Air Conditionin
\end{tabular}

\begin{tabular}{|l|l|l|l} 
ECBCS & 48 & Heat Pumping and Reversible Air Conditioning \\
\hline ECBCS & $48 a$ & Analysis of building heating and cooling demanos \\
\hline
\end{tabular}

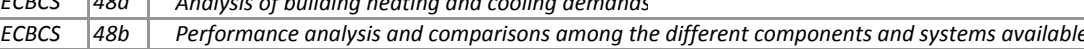

CBCS $48 \mathrm{C}$ Desig

ECBCS $48 d$ Global performance evaluation and commissioning methods

ECBCS 48 Case studies and/or demonstration

ECBCS $48 \mathrm{f}$ Dissemination

ECBCS 49 Low Exergy Systems for High Performance Buildings and Communities

ECBCS $49 a$ Methodologies

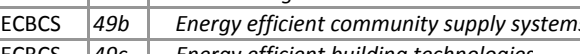

ECBCS $49 \mathrm{C}$ Energy efficient building technologies

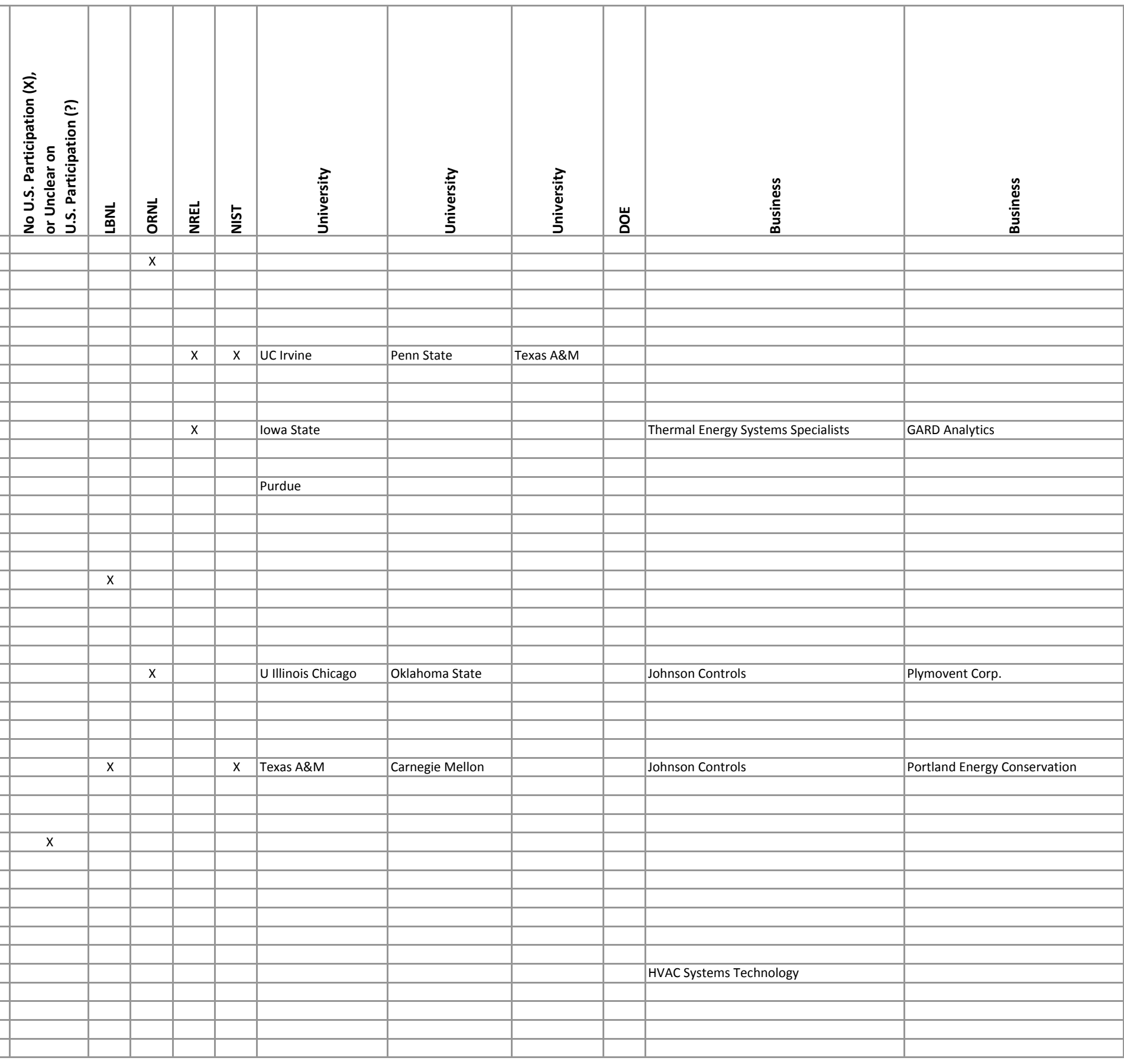


ECBCS 50 Prefabricated Systems for Low Energy Renovation of Residential Buildings

Concept definition and specification

\begin{tabular}{l|l|l|} 
CBCS & 500 & Integrated roof systems \\
CBCS & $50 \mathrm{C}$ & HVAC and solar Systems
\end{tabular}

ECBCS 50 fod Façade elements

ECBCS 500 Monitoring and dissemination

\begin{tabular}{l|l|l|l} 
ECBCS & 51 & Energy Efficient Communities \\
\hline ECBCS & $51 a$ & Methods and design tols \\
\hline
\end{tabular}

Meliods and design tools for energy efficient communities

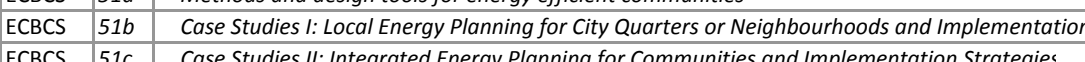

ECBCS $51 d$ Knowledge transfer and dissemination

DH\&C $n / a \quad$ Cost benefits and long term behaviour of a new all plastic piping system

DH\&C $n / a$ assessingthe actual annual energy efficiency of building-scale cooling sho

DH\&C $n / a \quad$ New materials and constructions for improving the quality and lifetime of DH pipes and joints

H\&C $n / a$ District heating distribution in areas with low heat demand density

ES $\quad 18$ Transportation of Thermal Energy Utilizing Thermal Energy Storage Technology

\begin{tabular}{|llll}
\hline ES & 18 & Iransportation of Thermal Energy Utilizing Thermal Energy Storage Technology \\
\hline ES & 19 & Optimised Industrial Process Heat and Power Generation with Thermal Energy Storage \\
\hline
\end{tabular}

ES 20 Sustainable Cooling with Thermal Energy Storage

ES $20 a$ Demonstration projects/system performance evaluation for an actual project

ES 200 Design procedure and system performance evaluation tools

\begin{tabular}{llll} 
& $20 c$ & Information dissemination and technology transfer \\
\hline ES & 21 & Thermal Response Test for Underground Thermal Energy Storages
\end{tabular}

\begin{tabular}{|l|l|l|}
\hline$E S$ & $21-1$ & TRT state-of-the-art \\
\hline$E S$ & $21-2$ & New developments \\
\hline
\end{tabular}

\begin{tabular}{|l|l|l|}
\hline$S S$ & $21-2$ & New developments \\
\hline$E S$ & $21-3$ & Evaluation methods and developments \\
\hline
\end{tabular}

\begin{tabular}{|l|l|l|}
\hline ES & $21-4$ & Standard TRT procedures \\
\hline ES & $21-5$ & Dissemination activities \\
\hline
\end{tabular}

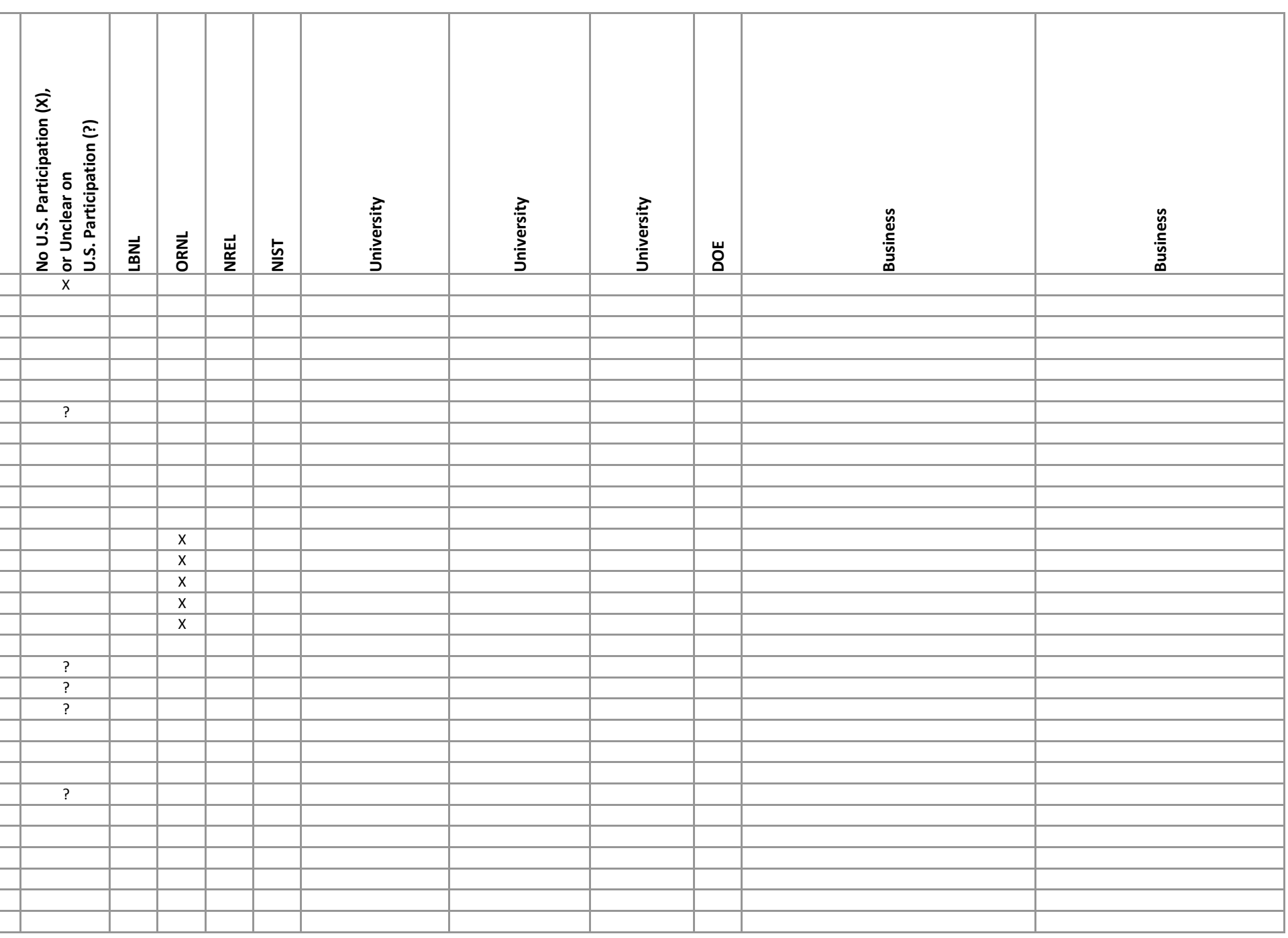


\begin{tabular}{|l|l|l|l|}
\hline $\mathrm{MP}$ & 31 & Advanced Modeling and Tools for Analysis of Eners \\
\hline $\mathrm{HP}$ & $31-1$ & Collection of available data from different supermarkets \\
\hline
\end{tabular}

HP $\quad 31-2$ Development of performance indices for supermarkets

HP $\quad 31-3$ Development and validation of a model library for specific supermarket equipment

\begin{tabular}{llll} 
& $31-4$ & Development of whole-building simulation models \\
\hline HP & $31-5$ & Comparison of results - different whole-building simulation models for selected case studies
\end{tabular}

\begin{tabular}{l|ll} 
HP & $31-6$ & Future perspectives and possibilities \\
\hline $\mathrm{HP}$ & $31-7$ & Deployment of the knowledge developed (indices, guidelines, papers, fact sheets,
\end{tabular}

HP $\quad 32$ Economical Heating and Cooling Systems for Low Energy Houses

\begin{tabular}{llll} 
HP & 33 & Compact Heat Exchangers in Heat Pumping Equipment \\
\hline HP & 34 & Thermally Driven Heat Pumps for Heating and Cooling \\
\hline
\end{tabular}

HP $34 a \quad$ Market overview and state of the art

HP $\quad 34 b$ Performance evaluation

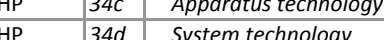

\begin{tabular}{|l|l|l|l}
\hline $\mathrm{HP}$ & $34 \mathrm{e}$ & Implementation \\
\hline
\end{tabular} \begin{tabular}{llll} 
SHC & 33 & Solar Heat for Industrial Process \\
\hline SHC & 34 & Testing and Validation of Building Energy Simulation Tools
\end{tabular}

\begin{tabular}{|l|l|l|}
\hline SHC & 34 & Testing and Validation \\
\hline SHC & 35 & PV/Thermal Systems \\
\hline
\end{tabular}

\begin{tabular}{llll} 
SHC & 36 & Solar Resource Knowledge Management \\
\hline SHC & 37 & Sdrat
\end{tabular}

\begin{tabular}{llll} 
& Advanced Housing Renovation with Solar \\
\hline SHC & 38 & Sol Air Condition
\end{tabular}

SHC 39 Polymeric Materials for Solar Thermal Applications

DSM 11 Energy Use, Metering and Pricing for Demand Management Delivery

DSM 12 Co-operation on Energy Standards

DSM 115 Network Driven DSM

DSM 16 Competititve Energy Services

DSM 17 Integration of Demand Side Management, Energy Efficiency, Distributed Generation and Renewable Energy Sources

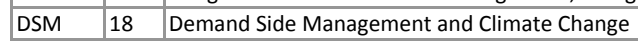

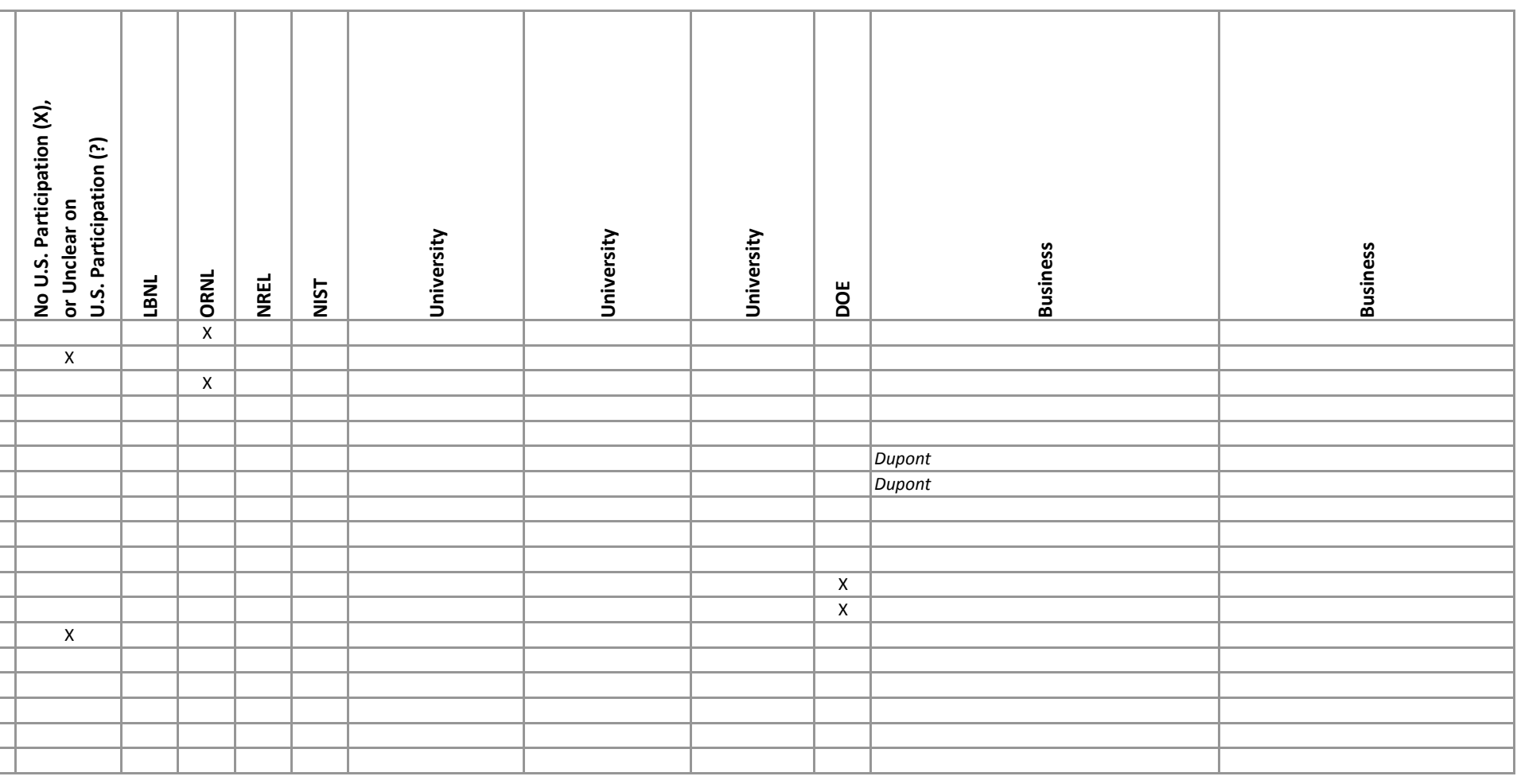

(20)
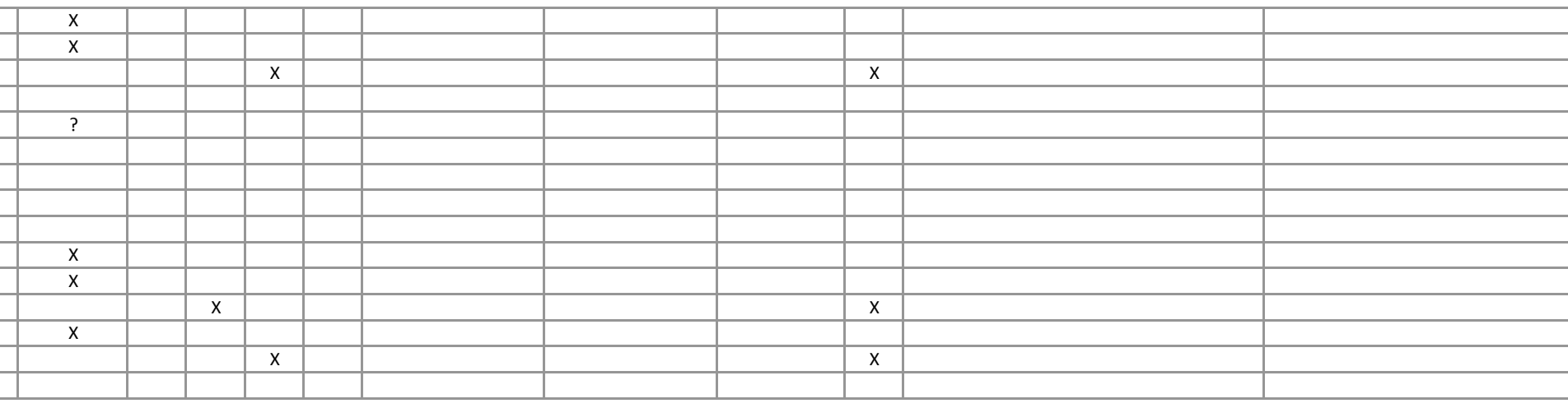


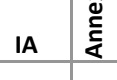

CBCS 41 Whole Building Heat Air and Moisture Response (MOIST-EN)

\begin{tabular}{ll|l} 
CCBCS & $41 a$ & Modelling and common exercises \\
CBCS & 416 & Expeling
\end{tabular}

\begin{tabular}{lll|l} 
ECBCS & $41 b$ & Experimental investigation \\
CBCS & $41 c$ & Boundary conditions
\end{tabular}

CCBCS $41 d \quad$ Long term performance and technology transfer

(C)

CBCS 4226 Developm

ECBCS $42 \mathrm{C}$ Technical, environmental and economic assessment of selected cogeneration applications

ECBCS 43 Testing and Validation of Building Energy Simulation Tools

ECBCS 430 Comparative tests

ECBCS 436 Subtasks empirical validation

ECBCS 44 Integrating Environmentally Responsive Elements in Buildings

CBCS $44 a$ Reactive building elements

(t)

CBCS $44 c$ Design tools and

ECBCS 45 Energy Efficient Electric Lighting for Buildings

ECBCS $45 a \quad$ Targets for energy performance and human well-being

ECBCS $456 \quad$ Innovative technical solutions

ECBCS $45 \mathrm{C}$ Energy-efficient controls and integration

CBCS $45 d$ information dissemination

$\begin{array}{llll}\text { ECBCS } & 46 & \text { Holistic Assessment Toolkit on Energy Efficient Retrofit Measures for Government Buildings }\end{array}$

ECBCS 460 Develop a database of "Energy Saving Technologies and Measures for Govern mssesment Gunde

ECBCS $46 c$ Develop "Best Practice Guidelines for Innovative Energy Performance Contracts"

ECBCS 46 Develop IT-toolkit "EnERGo"

ECBCS 47 Cost Effective Commissioning of Existing and Low Energy Buildings

ECBCS $47 a \quad$ Initial commissioning of advanced and low energy buildings

ECBCS $476 \quad$ Commissioning and optimization of existing buildings

ECBCS 477 Commissioning cost-benefit and persistence

ECBCS 48 Heat Pumping and Reversible Air Conditioning

\begin{tabular}{|l|l|l|l}
\hline$E C B C S$ & $48 b$ & Anarysirmance analysis and comparisons among the different components and systems available
\end{tabular}

ECBCS $48 \mathrm{C}$ Desig

ECBCS $48 d$ Global performance evaluation and commissioning methods

ECBCS 48 Case studies and/or demonstration

ECBCS $48 f$ Dissemination

ECBCS 49 Low Exergy Systems for High Performance Buildings and Communities

ECBCS $49 a$ Methodologies

\begin{tabular}{|l|l|l} 
ECBCS & $49 b$ & Energy efficient community supply systems
\end{tabular}

ECBCS $49 c$ Energy efficient building technologies

\begin{tabular}{|c|c|c|c|c|}
\hline 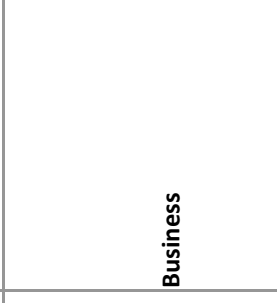 & 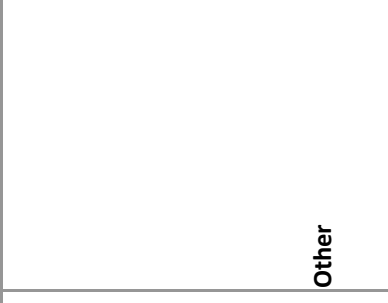 & 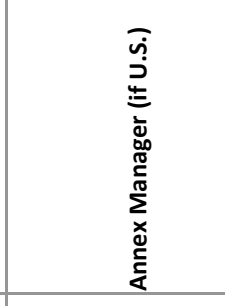 & 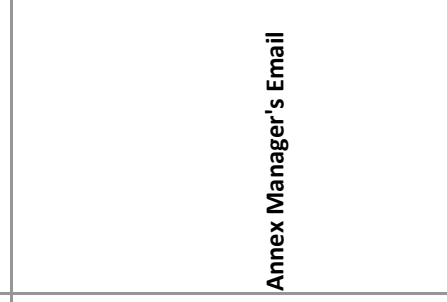 & 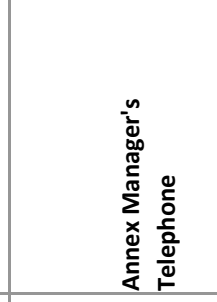 \\
\hline & & & & \\
\hline & & & & \\
\hline & & & & \\
\hline & & & & \\
\hline & & & & \\
\hline & & & & \\
\hline J. Neymark and Associates & & Ron Judkoff & ron judkoff@nrel.gov & Tel: +13033847520 \\
\hline & & & & \\
\hline & & & & \\
\hline & & & & \\
\hline & & & & \\
\hline & & & & \\
\hline & & & & \\
\hline & & & & \\
\hline & Army Corps Engineers ERDC + NAVFAC & Dr. Alexander Zhivov & Alexander.M.Zhivov@erdc.usace.army.mil & Tel: +1 2173734519 \\
\hline & & & & \\
\hline & & & & \\
\hline & & & & \\
\hline Siemens & & Natascha Castro & natascha.castro@nist.gov & Tel: +13019756420 \\
\hline & & & & \\
\hline & & & & \\
\hline & & & & \\
\hline & & & & \\
\hline & & & & \\
\hline & & & & \\
\hline & & Dave Solberg & davesolberg@hvacsystemstechnology.com & Tel: +1 6128696052 \\
\hline & & & & \\
\hline & & & & \\
\hline & & & & \\
\hline
\end{tabular}


$\dot{2}$

IA

ECBCS 50 Prefabricated Systems for Low Energy Renovationt Annexes

ECBCS $50 a$ Concept definition and specification

\begin{tabular}{|l|l|l|l} 
ECBCS & $50 b$ & Integrated roof systems \\
\hline CCBCS & $50 \mathrm{C}$ & HVAC and solar systems
\end{tabular}

ECBCS $50 d$ Façade elements

ECBCS 500 Monitoring and dissemination

\begin{tabular}{l|l|l|l} 
ECBCS & 51 & Energy Efficient Communities \\
\hline ECBCS & $51 a$ & Methods and design tols for \\
\hline
\end{tabular}

Coch
COCS and design tools for energy efficient communities

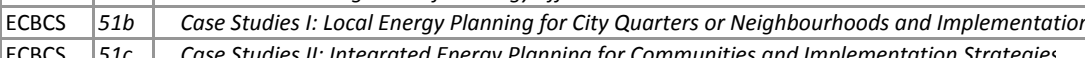

ECBCS $51 d$ Knowledge transfer and dissemination

DH\&C $\quad \mathrm{n} / \mathrm{a} \quad$ Cost benefits and long term behaviour of a new all plastic piping system

DH\&C $n$ /a Assessing the actual annual energy efficiency of building-scale cooling system

DH\&C $n / a \quad$ New materials and constructions for improving the quality and lifetime of DH pipes and joints

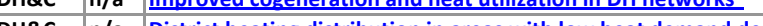

ES 18 Transportation of Thermal Energy Utilizing Thermal Energy Storage Technology

ES 19 Optimised Industrial Process Heat and Power Generation with Thermal Energy Storage

\begin{tabular}{llll} 
ES & 19 & Optimised Industrial Process Heat and Power Generation with Thermal Energy Storage \\
\hline ES & 20 & Sustainable Cooling with Thermal Energy Storage
\end{tabular}

\begin{tabular}{ll|l} 
ES & $20 a$ & Demonstration projects//ystem performance evaluation for an actual project \\
\hline$E S$ & 20 & Desion
\end{tabular}

$\begin{array}{lll}\text { ES } & 20 \mathrm{~b} & \text { Design procedure and system performance evaluation tools }\end{array}$

\begin{tabular}{llll} 
ES & $20 \mathrm{C}$ & Information dissemination and technology transfer \\
\hline ES & 21 & Thermal Response Test for Underground Thermal Energy Storages \\
\hline
\end{tabular}

\begin{tabular}{|l|l|l|l}
\hline$E S$ & $21-1$ & TRT State-of-the-art \\
\hline ES & $21-2$ & New developments \\
\hline
\end{tabular}

\begin{tabular}{|l|l|l}
\hline ES & $21-2$ & New developments \\
\hline ES & $21-3$ & Evaluation methods and developments \\
\hline
\end{tabular}

\begin{tabular}{|l|l|l} 
ES & $21-4$ & Standard TRT procedures \\
\hline ES & $21-5$ & Dissemination activities \\
\hline
\end{tabular} 
IA $\quad$ Current Annexes

\begin{tabular}{|l|l|l|}
\hline HP & 29 & Ground-Source Heat Pumps Overcoming Market and Technical Barriers \\
\hline HP & 30 & Retrofit Heat Pumps for Buildings \\
\hline
\end{tabular}

\begin{tabular}{|lll}
\hline HP & 31 & Advanced Modeling and Tools for Analysis of Energy Use in Supermarkets \\
\hline
\end{tabular}

$\begin{array}{llll}\text { HP } & 31-1 & \text { Collection of available data from different supermarkets } \\ \text { HP } & 31-2 & \text { Development of performance indices for supermarkets }\end{array}$

HP 31 31-3 $\quad$ Development and validation of a model library for specific supermarket equipment

\begin{tabular}{llll} 
HP & $31-5$ & Development of whole-building simulation models \\
\hline
\end{tabular}

\begin{tabular}{llll} 
HP & $31-6$ & Future perspectives and possibilities \\
\hline $\mathrm{HP}$ & $31-7$ & Deployment of the knowledge developed (indices, guidelines, papers, fact sheets,
\end{tabular}

HP 32 Economical Heating and Cooling Systems for Low Energy Houses

\begin{tabular}{|l|l|l|}
\hline HP & 33 & Compact Heat Exchangers in Heat Pumping Equipment \\
\hline HP & 34 & Thermally Driven Heat Pumps for Heating and Cooling \\
\hline
\end{tabular}

HP $34 a \quad$ Market overview and state of the art

HP $\quad 34 b \quad$ Performance evaluation

$\begin{array}{lll}\text { HP } & 34 c & \text { Apparatus technology } \\ \text { HP } & 34 d & \text { Spsem techolog }\end{array}$

HP 34 e Implementation

\begin{tabular}{|l|l|l}
\hline SHC & 32 & Advanced Storage Concepts for Solar and Low Energy Buildings
\end{tabular}

\begin{tabular}{llll} 
SHC & 33 & Solar Heat for Industrial Process \\
\hline SHC & 34 & Testing and Validation of Building Energy Simulation Tools
\end{tabular}

\begin{tabular}{l|l|l|l|l} 
SHC & 35 & PV/Thermal Systems \\
\hline SHC & 36 & Solar Resols & \\
\hline
\end{tabular}

\begin{tabular}{llll} 
SHC & 36 & Solar Resource Knowledge Management \\
\hline SHC & 37 & Advanced Housing Renovation with Solar and Conservation
\end{tabular}

ning and Refrigeration

39 Polymeric Materials for Solar Thermal Applications

DSM 11 Energy Use, Metering and Pricing for Demand Management Delivery

DSM 112 Co-operation on Energy Standards

DSM 15 Network Driven DSM

DSM 17 Integration of Demand Side Management, Energy Efficiency, Distributed Generation and Renewable Energy Sources

\begin{tabular}{|lll} 
DSM & 18 & Demand Side Management and Climate Change \\
\hline
\end{tabular}

\begin{tabular}{|c|c|c|c|c|}
\hline 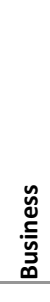 & 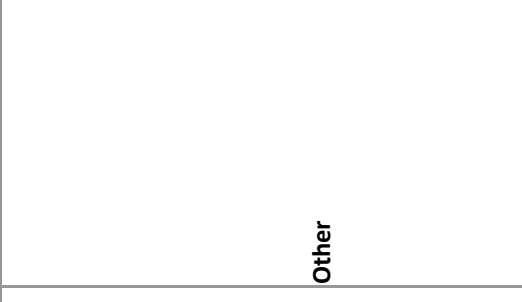 & 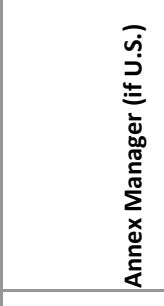 & 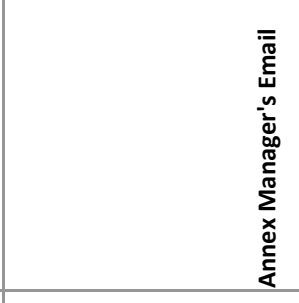 & 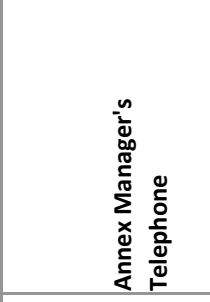 \\
\hline & & & & \\
\hline & & & & \\
\hline & & & & \\
\hline & & & & \\
\hline & & & & \\
\hline & & & & \\
\hline & & & & \\
\hline & & & & \\
\hline & & & & \\
\hline & 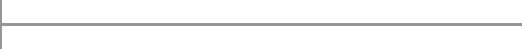 & & 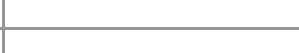 & \\
\hline & & & & \\
\hline & & & & \\
\hline & U.S. is operating agent for this task. & Ron Judkoff & ron judkoff@nrel.gov & Tel: +1 3033847520 \\
\hline & & & & \\
\hline & & & & \\
\hline & & & & \\
\hline & & & & \\
\hline & & & & \\
\hline & DOE Contact: Larry Mansueti & Brendan Kirby & kirbybj@ornl.gov & \\
\hline & DOE Contact: Stan Calvert stan.calvert@hq.doe.gov & Richard Diblasio & dick diblasio@nrel.gov & \\
\hline
\end{tabular}


ECBCS 41 Whole Building Heat Air and Moisture Response (MOIST-EN)

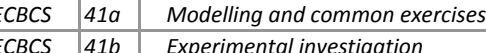

\begin{tabular}{|l|l|l|l} 
CBCS & $41 b$ & Experimental investigation \\
EBCS & $41 c$ & Boundary conditions
\end{tabular}

ECBCS 411 Long term performance and technology transfer

STCS 42 Simulation of Building-Integrated Fuel Cell and Other Cogeneration Systems (COGEN-SIM)

CBCS $42 a$ Development implogentation systems and occupant-driven electrical and domestic hot water usage patterns

ECBCS $42 \mathrm{C}$ Technical, environmental and economic assessment of selected cogeneration applications

ECBCS 43 Testing and Validation of Building Energy Simulation Tools

ECBCS 430 Comparative tests

ECBCS 436 Subtasks empirical validation

ECBCS 44 Integrating Environmentally Responsive Elements in Buildin

CBCS $44 a$ Reactive building elements

the the

CBCS $44 c$ Design tools and

ECBCS 45 Energy Efficient Electric Lighting for Buildings

ECBCS $45 a \quad$ Targets for energy performance and human well-being

ECBCS 456 Innovative technical solutions

ECBCS $45 \mathrm{C}$ Energy-efficient controls and integration

\begin{tabular}{|l|l|l|} 
ECBCS & $45 d$ & Information dissemination \\
\hline ECBCS & 46 & Holistic Assessment Toolkit on Energy Efficient Retrofit Measures for Government Buildings \\
\hline ECBCS & $46 a$ & Develop an energy assessment and andlysis methodology/protocol and Energy Assessment
\end{tabular}

ECBS 460 Develop a database of "Energy Saving Technologies and Measures for Governm Aseessment Guide

\begin{tabular}{ll|l} 
& \\
ECBCS & 460 & Develop "Best Practice Guidelines for Innovative Energy Performance Contracts"
\end{tabular}

ECBCS 46 Develop IT-toolkit "EnERGo"

CBCS 47 Cost Effective Commissioning of Existing and Low Energy Buiddines

BCS $47 a$ Initial commissioning of advanced and low energy buildings

ECBCS $47 \mathrm{~b}$ Commissioning and optimization of existing buildings

ECBCS 477 Commissioning cost-benefit and persistence

\begin{tabular}{llll} 
ECBCS & 48 & Heat Pumping and Reversible Air Conditioning \\
\hline ECBCS & $48 a$ & Analysis of building hesting and cooling dem
\end{tabular}

\begin{tabular}{|l|l|l|l}
\hline$E C B C S$ & $48 b$ & Pnarformance analysis and comparisons among the different components and systems available
\end{tabular}

ECBCS $48 \mathrm{C}$ Desig

ECBCS $48 d$ Global performance evaluation and commissioning methods

ECBCS 48 Case studies and/or demonstration

ECBCS $48 f$ Dissemination

ECBCS 49 Low Exergy Systems for High Performance Buildings and Communities

ECBCS $49 a$ Methodologies

\begin{tabular}{|l|l|l} 
ECBCS & $49 b$ & Energy efficient community supply systems
\end{tabular}

\begin{tabular}{lll} 
ECBCS & $49 \mathrm{C}$ & Energy efficient building technologies \\
\hline ECBCS & $49 d$ & Knowledce transer, disseminotion
\end{tabular}

\begin{tabular}{|c|c|c|c|}
\hline 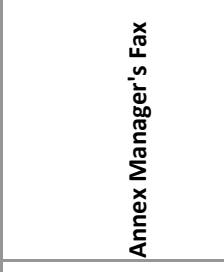 & 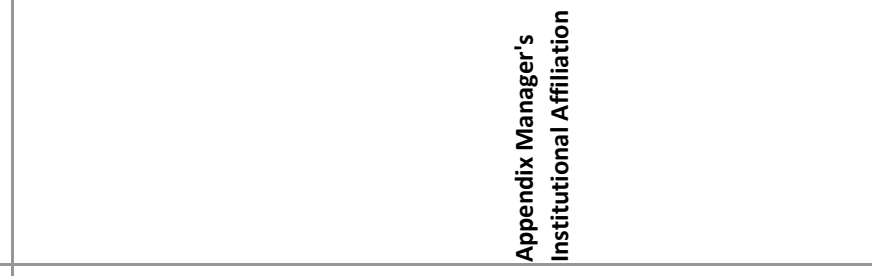 & 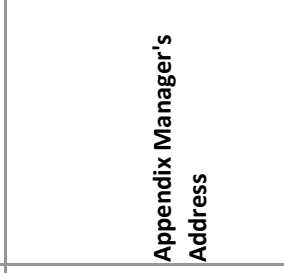 & 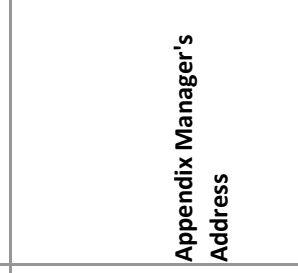 \\
\hline & & & \\
\hline & & & \\
\hline & & & \\
\hline & & & \\
\hline & & & \\
\hline Fax: +13033847540 & Buildings \& Thermal Systems Center, NREL & 1617 Cole Blvd. & Golden CO 80401 \\
\hline & & & \\
\hline & & & \\
\hline & & & \\
\hline & & & \\
\hline & & & \\
\hline & & & \\
\hline Fax: +1 2173736740 & Energy Branch ERDC - CERL U S. Army Corns of Engineers & 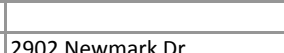 & Champaign - 61826-9005 \\
\hline & & & \\
\hline & & & \\
\hline Fax: +1 3019758973 & National Institute of Standards and Technology. Mechanical Systems and Control Group & 100 Bureau Drive Stop 8631 & Gaitherchurg MD 20899-8631 \\
\hline & 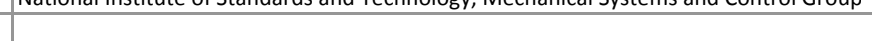 & 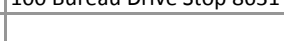 & Galthersourg ivi $20899-8631$ \\
\hline & & & \\
\hline & & & \\
\hline & & & \\
\hline & & & \\
\hline & & & \\
\hline & & & \\
\hline & HVAC Systems Technology & & \\
\hline & & & \\
\hline & & & \\
\hline & & & \\
\hline
\end{tabular}


$\dot{2}$

IA

ECBCS 50 Prefabricated Systems for Low Energy Renovation of Residential Buildings

CBCS 50 a Concept definition and specification

\begin{tabular}{|l|l|l|} 
ECBCS & $50 b$ & Integrated roof systems \\
\hline CCBCS & $50 \mathrm{C}$ & HVAC and solar systems
\end{tabular}

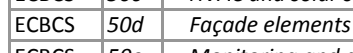

ECBCS 50 Monitoring and dissemination

\begin{tabular}{ll|l} 
ECBCS & 51 & Energy Efficient Communities \\
\hline ECBCS & $51 a$ & Methods and design tools for \\
\hline
\end{tabular}

$\begin{array}{llll} & \text { Methods and design tools for energy efficient communities }\end{array}$

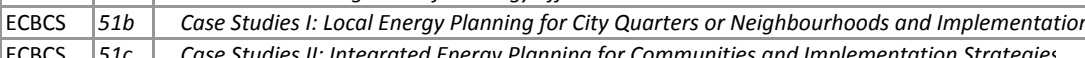

ECBCS $51 d$ Knowledge transfer and dissemination

DH\&C $\quad n / a \quad$ Cost benefits and long term behaviour of a new all plastic piping system

DH\&C $n / a$ Assessing the actual annual energy efficiency of building-scale cooling system

DH\&C $n / a \quad$ New materials and constructions for improving the quality and lifetime of DH pipes and joints

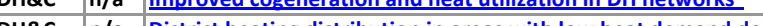

DH\&C $n / a$ District heating distribution in areas with low heat demand density

ES $\quad 18$ Transportation of Thermal Energy Utilizing Thermal Energy Storage Technology

19 Optimised Industrial Process Heat and Power Generation with Thermal Enesy Storas

20 Sustainable Cooling with Thermal Energy Storage

$\begin{array}{ll}20 a & \text { Demonstration projects/system performance evaluation for } \\ 20 \mathrm{~b} & \text { Design procedure and system performance evaluation too }\end{array}$

$20 c$ Inform procedure and system performance evaluation toor

21 Thermal Response Test for Underground Thermal Energy Storages

\begin{tabular}{l|l|l|l} 
ES & $21-1$ & TRT state-of-the-art \\
\hline ES & $21-2$ & New developments \\
\hline
\end{tabular}

\begin{tabular}{|l|l|l}
\hline ES & $21-2$ & New developments \\
\hline ES & $21-3$ & Evaluation methods and developments \\
\hline
\end{tabular}

\begin{tabular}{|l|l|l|}
\hline ES & $21-4$ & Standard TRT procedures \\
\hline ES & $21-5$ & Dissemination activities \\
\hline
\end{tabular} 
US PARTICIPATION IN RESEARCH PROJECTS OF IMPLEMENTING AGREEMENTS IN BUILDING SECTOR

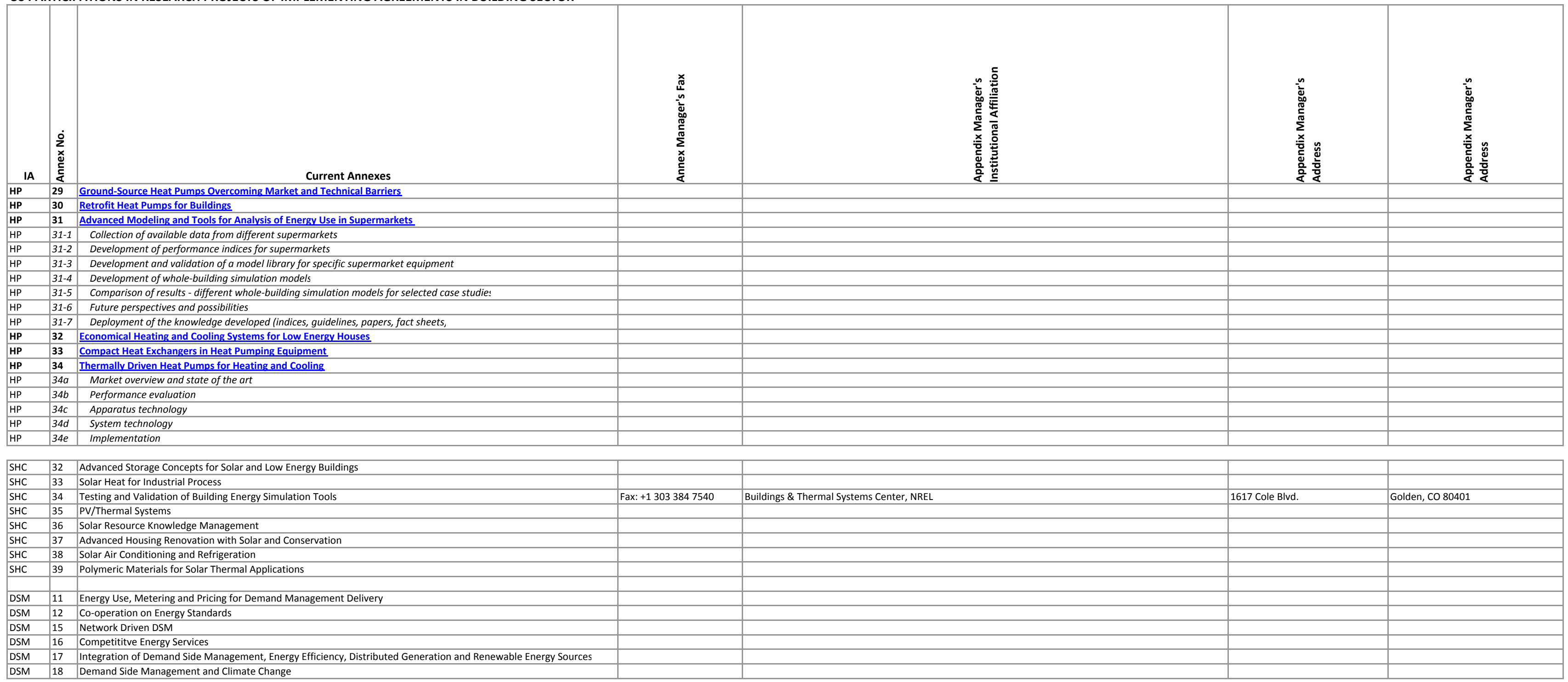




\section{$\underline{\text { Appendix G. Presentation of PNNL-LBL Interim Evaluation Findings }}{ }^{11}$}

${ }^{11}$ See next page for the text of this appendix. 


\title{
IEA Implementing Agreements: An Interim Assessment
}

\author{
Meredydd Evans \\ Paul Runci \\ Pacific Northwest National Laboratory \\ Alan Meier \\ Lawrence Berkeley National Laboratory
}

January 24, 2008 


\section{Findings on Implementing Agreements}

- Significant and tangible results that could not have been achieved by BTP alone

$\checkmark$ Reliable mechanism for effective international collaboration

Don't expect "gadgets"

- National Teams are "force multipliers"

$\checkmark$ Better coordination within DOE $\rightarrow$ enhanced value 


\section{Outline}

- Study Approach

What is an Implementing Agreement?

-Findings:

- Impacts

- Challenges

- Other national evaluations

- Preliminary Recommendations 


\section{Rationale for the Review}

-DOE has participated in IEA implementing agreements since the 1970s

- These activities entail commitments of research funds and staff time

-Worthwhile to periodically review benefits and costs of participation 


\section{Questions under Study}

How do the Implementing Agreements operate?

- What are the impacts and benefits of participation in the Implementing Agreements?

- Does DOE use the Implementing Agreement system effectively?

- Is the IEA Implementing Agreement an effective method of undertaking research? 


\section{Approach in this Evaluation}

- Interview key players (and bit players) in IAs most relevant to BTP (October '07-January '08)

- Over 50 interviews, including many DOE staff

- Review documents

- Gather financial data

- Synthesize, compare, contrast and prepare recommendations 


\section{Implementing Agreement $=$ Technology Collaboration}

- International Energy Agency provides legal framework for technology cooperation

- Avoids re-inventing multilateral agreements

- An IA is formed when countries wish to collaborate on research in a general area:

- Energy Conservation of Buildings and Community Systems (ECBCS)

- Heat Pumps

- Solar Heating and Cooling

- DSM

- Efficient Appliances

- Annexes (or Tasks) are formed within an IA to study specific topics 


\section{Organization of an IA: Roles and Relationships}

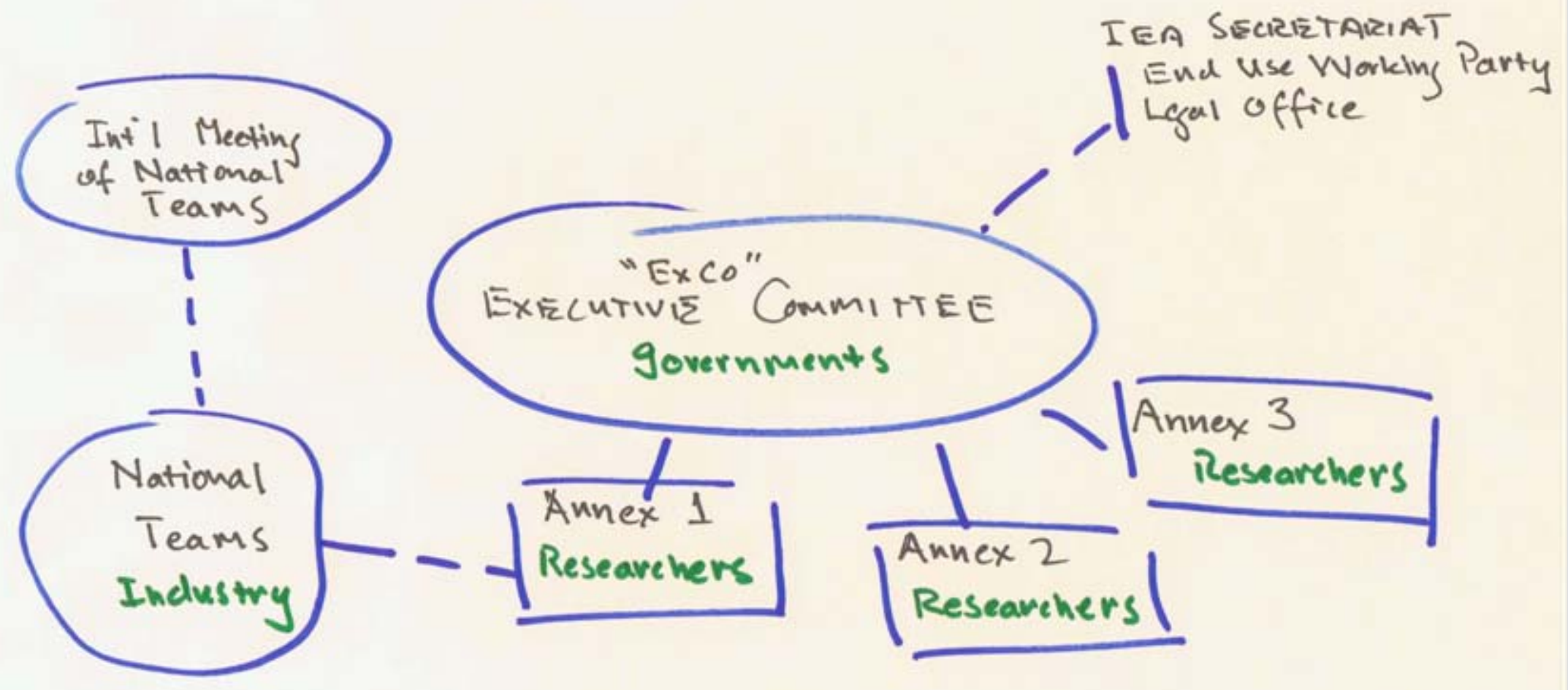

Items in green represent stakeholders. Battelle 


\section{Organization Notes}

- The IAs work almost completely independently of the IEA Secretariat

- ExCos approve new Annexes, manage operations

- Funding arrangements in Annexes vary

- Some share funds

- Some share tasks

- An "operating agent" is often selected

- BTP represents US on IAs but other groups fund some Annexes with cash and in-kind services

- ASHRAE, Army Corps of Engineers, DOE OIP, Purdue, etc. 


\section{Birth of an IA, Annexes}

1. Countries discover common energy R\&D interest

2. Informal meeting of governments, researchers, industry to outline interests, scale of commitments

3. IEA legal office helps group form IA after $>2$ countries commit

- Scope, charter, ExCo, funding for management

4. Countries form national teams

5. Groups of countries propose specific tasks as Annexes

- Scope of work, operating agent, funding, schedule of deliverables, reporting, etc.

- ExCo approves and oversees activities

- 3 year typical lifetime with end-of-term report

6. ExCos report to IEA Secretariat

- $\quad$ Progress reports to End Use Working Party

- Legal aspects to Legal Office

- $\quad$ IEA Desk Officer monitors activities 


\section{National Teams}

$\checkmark$ Coordinate US participants, disseminate information, organize $\sim 2$ meetings/year

- Prepare and disseminate newsletters to industry and other stakeholders nationwide

- Spawn proposals for new Annex agreements, as demanded by industry

- Vehicle for cost-sharing with industry

- Performance of US heat pump national team is a good model for other national teams

- Most IAs in US do not have national teams; common in other countries 


\section{An Example: Energy Conservation in Buildings and Community Systems (ECBCS)}

Created in 1975 to accelerate adoption of efficient technologies in buildings and community systems

25 members collaborate mainly through task sharing

$\checkmark 12$ active annexes, including:

- Air Infiltration and Ventilation Center

- Whole building heat, air and moisture response

- Testing and validating simulation tools

- Efficient future lighting

- Cost effective commissioning for low energy buildings 


\section{Types of Impacts and Value}

- Provide "Intelligence gathering" function: Annexes are windows on the world

- Innovations, best practices, codes and standards

- Result appear here long before they appear in journals or on store shelves

- Facilitate research otherwise not possible

- Sustain dialogue among industry participants and government domestically and internationally

- Through National Teams

Lead to subsequent business and research opportunities 


\section{Examples of Impacts: Heat Pump Agreement}

Equations of state for CFC replacements

- Allowed faster shift to non-CFC refrigerants by a few years and lowered costs for industry

- Sterling engine heat pumps:

- US learned about state of the art in Germany and Japan

- Learned to avoid blind research alleys

- Heat pumps overall: "US has been a net importer of information"

- But also missed opportunities: Scandinavian solutions for indoor air quality in zero-energy homes 


\section{More Examples of Impact}

- Moisture in buildings

- US had little expertise so researchers were able to learn from Europeans

- Building simulation benchmarking (BESTEST)

- US had insufficient resources to do alone

- Results adopted by ASHRAE

- Demand Response Coordinating Committee for domestic coordination

- US ESCOs were able to learn about and shape the European ESCO market; US ESCOs have seen a large increase in business in Europe as an indirect result

- India designing a national DSM program relying on guides and a database from the IA

- The US market transformation-technology procurement efforts were designed drawing heavily from experience gained in the IA 


\section{Challenges}

- Dissemination

$\checkmark$ Coordination in DOE

- Sharing

- Using

- Travel Funding

- Need to Ensure Continuity 


\section{Information Dissemination}

- National Teams' meetings \& newsletters principal means of communication with industry; Other broad dissemination ad hoc

-1-year document embargo often a barrier

- More summaries for non-experts could help expand use of material

- Communication within DOE problematic (especially across IA teams)

- How to improve intra-BTP dissemination? 
IEA SHAC Implementing Agreement - Current Activities

\begin{tabular}{|c|l|c|c|}
\hline $\begin{array}{l}\text { Task } \\
\text { No. }\end{array}$ & Task Title & $\begin{array}{l}\text { US } \\
\text { Participation }\end{array}$ & $\begin{array}{c}\text { Relevant to US } \\
\text { SH\&C Program }\end{array}$ \\
\hline $\mathbf{3 9}$ & Polymeric Materials for Solar Thermal Applications & No & Yes \\
\hline $\mathbf{3 8}$ & Solar Air-Conditioning and Refrigeration & No & Yes \\
\hline $\mathbf{3 7}$ & Advanced Housing Renovation with Solar \& Conservation & No & Yes (Funded by \\
OSET)
\end{tabular}




\section{Previous Evaluations}

- Many countries have evaluated the IAs since 2003: Australia, Austria, Finland, Germany, New Zealand, Netherlands, Sweden, Turkey, United Kingdom

- Overall, found very valuable

- Austria: participation in past 5 years has led to 21 new international collaborations and new IP

- Interestingly, after evaluation, many countries created "national coordinating committees"

- Better decision making and information flow across IAs 


\section{Reviewing Returns on Investment}

- Useful to collect financial data to get a better picture of the value

- Ex.: Is travel really that expensive? IA costs compared to similar domestic investments? Role of industry?

$\checkmark$ Review both total costs and DOE costs (IA contributions, task sharing, travel)

- Expect to know general picture, but not exact

- Request help on tracking down costs on DOE side 


\section{Findings}

- Significant and tangible results that could not have been achieved alone-for US and partner countries

- Our findings and those of other studies

- Reliable mechanism for effective international collaboration

- IEA umbrella and legal framework speeds formation and sustainability

Don't expect "gadgets"

- Most likely outputs are standardized methods, programs, and data

- National Teams are "force multipliers"

- BTP program managers lack time and resources to do this alone

- Better coordination within DOE $\rightarrow$ enhanced value 


\section{Preliminary Recommendations}

- Encourage More National Teams (within IAs)

- Reassess Cost-Benefit Equation, especially re. travel

- Improve Internal DOE Coordination

- Consider National Coordinating Committee (across IAs) 


\section{$\underline{\text { Appendix H. Current Annexes of the Agreements Studied }}{ }^{12}$}

\section{Energy Conservation in Buildings \& Community Systems}

- Air Infiltration and Ventilation Centre. For over 20 years now, the Centre has provided technical support in air infiltration and ventilation research and implementation.

- Evaluation and Demonstration of Domestic Ventilation Systems. This annex seeks to develop methods for evaluating domestic ventilation systems and to verify the methods using accumulated data.

- Control Strategies for Hybrid Ventilation in New and Retrofitted Office Buildings. The annex aims to develop control strategies for hybrid ventilation systems, develop methods to predict hybrid ventilation performance, and promote energy and cost-effective hybrid ventilation systems.

- Retrofitting in Educational Buildings: Energy Concept Adviser for Technical Retrofit Measures. Objectives include developing simple tools for retrofit concepts to allow the decision maker to evaluate integrated construction, installation, and lighting measures.

- Low Exergy Systems for Heating and Cooling. This annex is evaluating the impact of replacing high value energy sources (fossil fuels, electricity, etc.) with low value energy sources. An assessment of existing technologies and components for low exergy heating and cooling will also take place.

- Solar Sustainable Housing. The annex aspires to significantly increase solar sustainable housing in participating counties by 2010. This effort will be accomplished by presenting builders and real estate investors with: successful projects, cost-benefit analysis, and resources to improve energy, environmental and cost performance of already existing strategies.

- High Performance Thermal Insulation Systems. The objective of this annex is to develop reliable components for buildings based on high performance thermal insulation and to encourage competitive products which are available on the market, such as Vacuum Insulation Panels.

- Commissioning of Building HVAC Systems for Improving Energy Performance. The goal of this annex is to optimize energy performance in buildings and will be achieved by developing, validating and documenting tools for commissioning buildings and building services.

- Whole Building Heat, Air and Moisture Response (MOIST-EN). The first objective of this annex is to foster a basic understanding of short-lived moisture storage in different finishing materials and moisture exchange with the indoor air. The second objective is to conduct an analysis of the effects of the whole building HAM-response on comfort, enclosure durability and energy consumption. Simultaneously, measurements will be taken regarding comfort, enclosure durability and energy consumption, with air-tightness, moisture management, thermal insulation and humidity storage as some of the measures projected.

\footnotetext{
12 The Energy-Efficient Electrical Equipment Implementing Agreement is still a work in progress.
} 
- Simulation of Building-Integrated Fuel Cell and Other Cogeneration Systems (COGEN-SIM). This annex aims to develop simulation methods that advance the design, operation, and analysis of residential cogeneration systems. Moreover, this annex seeks to develop models to simulate the performance of fuel cells and other cogeneration systems and associated equipment, characterize occupant-driven electrical usage patterns for various demographic groups and geographical locations, implement the new models into existing whole-building simulation programs, validate the models and their implementation into the whole-building simulation programs, and perform technical, environmental, and economic assessments of selected cogeneration applications using new models.

- Testing and Validation of Building Energy Simulation Tools. This annex involves research in the development of comprehensive energy analysis tools. This goal will be pursued by creating and disseminating a comprehensive and integrated suite of IEA Building Energy Simulation Test cases for evaluating, diagnosing, and correcting building energy simulation software, maintaining and expanding analytical solutions for building energy analysis tool evaluation, and creating and making widely available high quality empirical validation data sets.

- Integrating Environmentally Responsive Elements in Buildings. The objectives of this annex include defining state-of-the-art reactive building elements, improving and optimizing reactive building elements and technologies, and developing and optimizing new building concepts with integration of reactive building elements on the environmental performance of buildings.

- Energy-Efficient Future Electric Lighting For Buildings. The first objective of this annex is to identify and stimulate the widespread use of appropriate energy efficient, high-quality technologies and their integration with other building systems, and promoting them to become the preference among lighting designers, owners, and users. The second objective involves the assessment and documentation of the technical performance of existing, yet largely underutilized, innovative lighting technologies as well as up-and-coming lighting technology.

- Holistic Assessment Tool-kit on Energy Efficient Retrofit Measures for Government Buildings (EnERGo). This annex seeks to provide tools and guidelines for decision makers, energy managers, performance contractors and designers in order to improve the working environment of government buildings through energy-efficient retrofitting projects, to provide recommendations on how to operate the retrofitted buildings, to promote energy and cost-effective retrofit measures by providing successful examples, to support decision makers in evaluating the efficiency and acceptance of available concepts, and to improve application of Energy Performance Contracts for Government building retrofit measures.

- Cost-Effective Commissioning for Low-Energy Buildings. This annex aims to extend previously developed methods and tools to address advanced systems and low energy buildings, automate the commissioning process to the extent practicable, develop methodologies and tools to improve operation of buildings in use, and quantify and improve the costs and benefits of commissioning.

- Heat Pumping and Reversible Air Conditioning. 


\section{Demand-Side Management}

- International Database on DSM Technologies and Programmes. The annex's initial subtask, INDEEP Online Database, increases government utilization of end-use efficiency programmes by providing access to information on such programmes. DSM and EE Programme Evaluation Guidebook, the second subtask, aims to research and develop an evaluation guidebook available to both governmental and non-governmental sectors and to DSM programmes focused on greenhouse gas emissions.

- Energy Use, Metering and Pricing for Demand Management Delivery. The goal of this annex is to encourage smaller customers to evaluate and reduce their energy demand and to facilitate an increased participation in the demand side of competitive energy markets.

- Co-operation of Energy Standards. An increase in stringent global warming policy and strengthening in standards combined with already existing policies has the potential to account for a majority of upcoming energy and greenhouse gas emissions reductions.

- Network Driven DSM. This annex aims to identify cost-effective DSM policies to relieve both time-related and location-related electricity network constraints, especially in areas where energy demand is soaring and network infrastructure is ageing.

- Integration of Demand Side Management, Energy Efficiency, Distributed Generation and Renewable Energy Sources. The overlying objective involves research on how to achieve the optimal integration of flexible demand (demand response, demand side management) with distributed generation, energy storages and smart grids and thus decrease issues associated with irregular distributed generation in the physical electricity systems and at the electricity market.

- Demand Side Management and Climate Change. This annex examines potential opportunities to curtail greenhouse gas emissions through demand side management measures and the effects this reduction could have on electricity systems. Further measures will be implemented to maximize the emissions reductions and electricity system benefits.

\section{District Heating and Cooling}

- Several DHC/CHP Projects. This annex proposes a series of projects involving district heating and cooling, including effectiveness and benefits resulting from a new, all-plastic piping system; assessing the energy efficiency behind buildingscale cooling systems; evaluating new materials and methodologies for improving the quality and lifetime of district heating pipes; evaluating thermal, mechanical and environmental performance; improving the utilization of wasted heat energy in district heating networks; and the evaluation of district heating distribution in areas with low heat demand density. 


\section{Heat Pumping Technologies}

- Ground-Source Heat Pumps Overcoming Market and Technical Barriers. The annex will continue researching innovative ideas and pinpoint systems that could enhance efficiency and marketability of ground-source heat pump systems.

- Retrofit Heat Pumps for Buildings. The annex, in attempts to adapt heat pump systems to already existing residential buildings, will continue to investigate the availability, technology, profitability, and research and development trends of heat pump systems. These systems are beneficial in their ability to reduce fossil fuel consumption and the associated greenhouse gas emissions.

- Advanced Modeling and Tools for Analysis of Energy Use in Supermarkets. This annex aims to develop and utilize tools to aid in analyzing energy performance in supermarkets, the most energy intensive buildings in the commercial sector. It also seeks to formulate energy efficient indices for different countries and systems.

- Economical Heating and Cooling Systems for Low Energy Houses. The underlying objective of this annex is to survey varying heating and cooling systems for low energy houses in order to advance design of these systems and provide cost-effective systems for these buildings.

- Compact Heat Exchange In Heat Pumping Equipment. The objectives of this annex include limiting environmental impacts during manufacture and improving overall system performance while identifying compact heat exchangers that may be used in heat pumping equipment. Additional goals include researching reliable methods of predicting measurements associated with these types of heat exchangers and identifying relevant restrictions, such as maximum pressures, minimum diameters and estimated costs.

- Thermally Driven Heat Pumps for Heating and Cooling. The annex aspires to minimize environmental impacts stemming from thermally driven heat pumps. Research will be compiled to examine the logistics behind thermally driven heat pumps in a variety of climates and countries. Emphasis will be placed on areas identified as providing the greatest environmental and market benefits. 


\section{Appendix I. Notes From Building Technologies Program IEA Day,}

May 8, 2008

\section{Background}

The Building Technologies Program (BTP) funded an evaluation of past and ongoing collaborative R\&D activities through the International Energy Agency (IEA). BTP participates in a number of implementing agreements (IAs) which are cooperative agreements under which R\&D tasks, known as "annexes" are conducted. The evaluation found that the IAs have produced impressive results that have contributed to the success of BTP goals. Examples include work on standards for analytic tools regarding building energy use, and experience gained with foreign country bulk procurements for energy efficiency. Overall, the most suitable projects for international collaboration appear to involve modeling and analytical tools, test procedures, and benchmarking measurements.

The evaluation report:

- Evaluated the benefits and costs of BTP participation in IEA activities,

- Created a mapping of current IEA Implementing Agreement annexes to the BTP multiyear plan (MYP) tasks, and goals, and

- Produced a "Users Guide" to assist new BTP staff in initiating and managing work with the IEA framework.

BTP convened a workshop of staff currently managing R\&D under one or more IEA implementing agreement annexes. The purpose of the workshop was to better understand how BTP can use international cooperative R\&D strategically and how to better integrate IEA activities into the multiyear plans. While the report did provide some mapping of current work to the plans, there are potentially gaps or opportunities for more strategic use of these agreements. International collaboration can provide important insights into leading research globally, thus reducing the cost of new R\&D, if it is well targeted to domestic program needs.

\section{Introduction}

Interest in DOE's IEA activities has grown in recent years. Assistant Secretary Andrew Karsner expressed interest in having the United States learn more from the experiences of other countries in key areas such as phase-out of incandescent bulbs and new building codes and standards for energy efficiency. Also, since IEA activities have become more closely linked to the G8 agenda since the Gleneagles summit, there has been a corresponding interest in deeper engagement on the part of DOE management.

BTP has a long history of involvement in IEA IAs dating back to the founding of the IEA and predating the founding of DOE. While DOE has many ongoing activities in this regard and has a wealth of experience, there is a need to make the management process more transparent and to integrate and align these activities with BTP strategy. This workshop is a first step toward that goal and toward maximizing the value that BTP and DOE derives from its work with IEA. 


\section{How Implementing Agreements (IAs) Work}

The IEA IAs are frameworks to facilitate collaborative research and sharing information. The goal is to provide new BTP staff basic information about IAs and how best to use them:

- Understand benefits, costs, time scale, obligations,

- Unique BTP aspects, and

- IEA Contacts.

The IEA Secretariat, End Use Working Party, and IEA Legal Office form the framework, overarching management, and support organization for the development of IAs. Each agreement is managed by an executive committee (ExCo) made up of government representatives. Each agreement initiates one or more annexes with specific goals, sponsoring countries, research teams, and an "operating agent" to manage the work.

IAs are initiated at

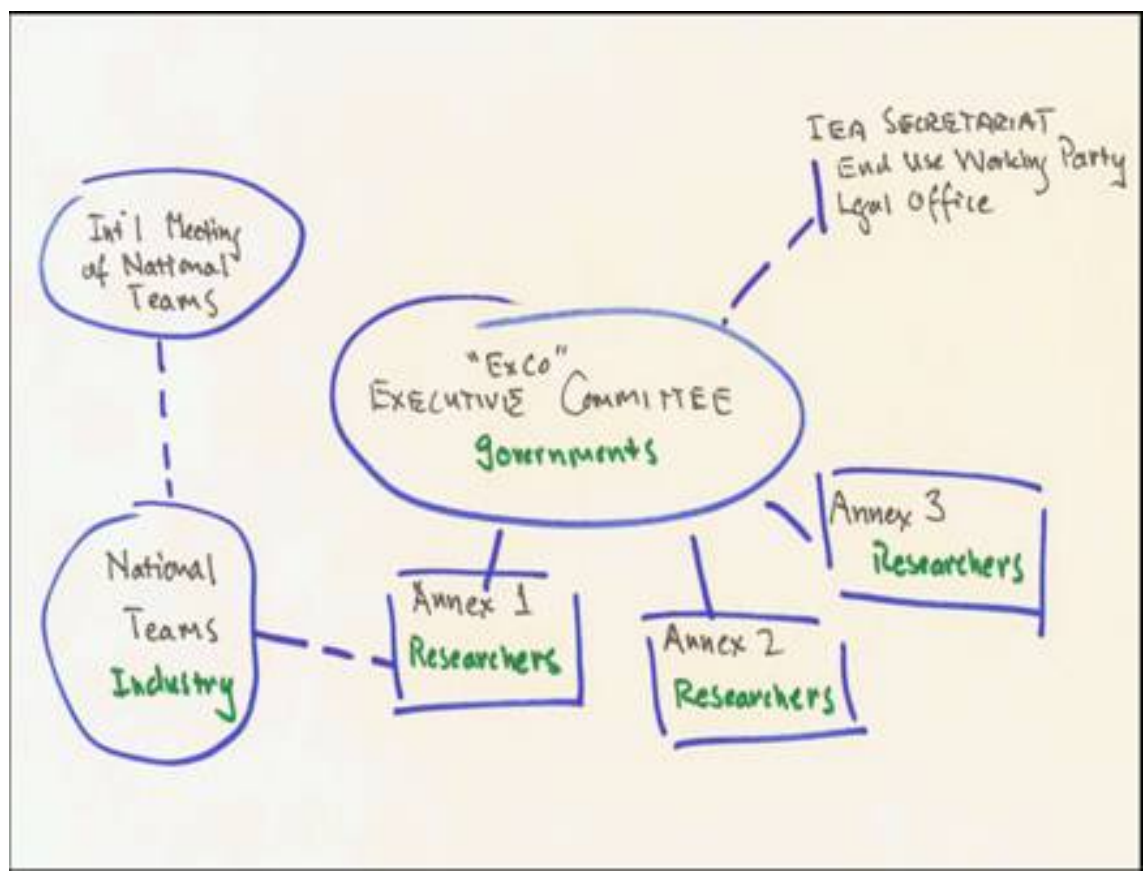
a relatively high level, are long lasting, and are relatively rare events. It is easier to form an IA than an independent multilateral collaboration. The ExCo manages the IA. Members of the ExCo are typically program managers from energy or economic ministries, counterparts of DOE. The ExCo:

- Considers proposals for new annexes,

- Reviews progress \& results,

- Manages technical tours,

- Administers the budget,

- Selects operating agents,

- Administers "centers" (RD\&D facilities),

- Reports periodically to standing committees in the IEA, and

- Provides a link to "national teams."

Annexes are established within IAs. Researchers, program managers, and industry identify a common need (e.g., test procedure, database, modeling tool). Countries and 
researchers are solicited to participate. A workplan is developed and a proposal is submitted to the ExCo for approval.

Participating countries may contribute through:

- Cash (to fund single researcher),

- Portion of coordinated research, and

- In-kind services.

The detailed research plan establishes tasks assignments, schedules \& deliverables. Technical meetings are held with member countries hosting meetings on a rotating assignment. Participants, mostly from universities, national labs, and industry, meet to discuss and analyze recent results as well as exchange information about related research and plans within their respective countries. A final report is eventually produced with presentation of results to the ExCo and national teams.

\section{Evaluation Findings}

There were four questions under study:

- How do the IAs operate?

- What are the costs, benefits, and other implications of participation in IAs?

- Does DOE use the IA system effectively? and

- Is the IEA IA an effective method of undertaking research?

The research approach was to conduct interviews with a wide sample of participants in IAs most relevant to BTP:

- Energy Conservation in Buildings and Community Systems,

- Heat Pumping Technologies,

- Solar Heating and Cooling,

- Demand Side Management, and

- Energy Efficient Electrical Equipment.

In addition, the research team reviewed documents, gathered financial data, and mapped IEA work to the current plan. Finally, the team prepared recommendations.

The team found that significant and tangible results were produced through this cooperative research that could not have been achieved alone by the United States or partner countries. IAs are a reliable mechanism for effective international collaboration, as the IEA umbrella and legal framework speeds formation and provides stable and durable framework.

The results of this cooperative research are less likely to result in products or proprietary intellectual property. Instead, the most likely outputs are standardized methods, programs, and data. National teams, comprised of government, national labs, universities, and industry, are "force multipliers" in assimilating research results into national programs. 
A secondary benefit of international collaboration is the "intelligence gathering" function. The R\&D annexes are windows on the world, giving insight into innovations, best practices, codes, and standards development long before such information appears in journals or IEA final reports. Participation in these agreements creates a sustained dialogue among industry participants and government domestically and internationally.

Some specific examples of impacts are:

- Development of equations of state for CFC replacements that allowed a faster shift to non-CFC refrigerant and lowered costs to industry,

- Exposure to state-of-the-art research in Germany and Japan on sterling engine heat pumps that allowed the United States to avoid blind alleys,

- Understanding of moisture in buildings where the United States had little expertise and so researchers were able to learn from Europeans, and

- Cooperative development of building simulation benchmarking (BESTEST), as the United States had insufficient resources to go it alone (results were adopted by ASHRAE).

Workshop participants were presented with mappings of various implementing agreements and annexes to the current BTP multiyear plan.

\section{Comments}

\section{General}

- Add detail to each IA diagram to show, for example, what level of officials is involved in which element of the IA (e.g., ExCo, operating agent, annex, national team, etc).

- It would be useful to include funding formulas for each of the IAs since this information could inform future negotiations.

- Not all IAs are alike and some differ significantly from others. This means that funding arrangements also vary accordingly, with cost sharing in some cases and task sharing in others. For example, the Heat Pump IA is mainly an informationsharing agreement, which makes resource pooling more sensible in this case than in others. We need to consider these funding possibilities from the outset since participation costs can be decisive in determining whether or not we will sign on to an annex.

- The ExCo provides budget information for cost-shared agreements but not at the annex level or in cases where there is no cost sharing among participants.

- Tracking funding, once it has left DOE, is very difficult. It would be useful if we could at least know what other countries are doing and funding within an IA. But the key question remains not how much participants are spending but what value they are getting from an IA/annex.

- Participation in an IA can take on different hues as there are multiple ways of setting up IAs and annexes. Sometimes DOE will pay the entry fee for industry in exchange for in-kind project funding from industry. Similarly, DOE often provides direct support for national lab involvement in projects and for IA administration, as in the case of the Heat Pump Agreement. 


\section{Intramural and Extramural IA Communications}

- Industry often hears about IA and annex activities through informal conversations at association meetings such as the annual ASHRAE meeting. Often, industry representatives then approach DOE and ask it to sign on to a particular annex. This is a very hit-or-miss means of communicating, and a more systematic approach would be preferable.

- Who has the authority to enter IAs and annexes? Who within the federal government has "landlord" status over interactions with the IEA? Clearly the State Department does, but DOE also appears to have jurisdiction. What is the procedure for other agencies such as EPA when they want to get involved in IAs?

- Since communications related to IAs are informal within DOE, it may be worthwhile to have an annual intramural symposium on IEA (and other international) activities as a means of taking stock and sharing information periodically.

- Another way to promote both visibility and information sharing could be for DOE to sponsor more ExCo meetings in the United States. Currently, ExCo meetings are only held here about every ten years.

\section{IAs and Annexes as Strategic Relationships}

- It would also be helpful to make the annex formation/approval process more transparent. How do we choose which ones to join? How do we know if there will be sufficient funding for the life of the project? We need to know these things in advance.

- In thinking about the current and future BTP portfolio of IA activities, we need to review the current set of annexes and IAs to establish what we are now doing and what we could/should be doing to further strategic priorities and goals.

- It is also important to consider that involvement in IAs may yield value from a technological standpoint, a policy standpoint or both. We should not think of IAs as strictly technology collaborations, since they are part of a broader set of tools that can serve strategic policy ends. Value must be considered in relatively broad terms.

- The question of whether or not to join an annex may be particularly relevant when an annex deals with a technology area in which the United States has a lead, for instance in solid state lighting. In cases such as this, we could potentially have more to lose by sharing information than we might stand to gain.

\section{Mapping}

- A key next step may be to map all BTP international activities since IEA is only part of the picture. Bilateral agreements, ISO, and APP are also important vehicles for international collaboration.

- It is important to realize that the reason the BTP often chooses not to participate in annexes is due to the fact that the technologies addressed may not apply to the U.S. context. There are building technologies that make sense, for example, in 
Europe that are not applicable here, even though it may appear to be a promising opportunity for collaboration on the surface. Regardless, we need a system of documenting "go/no-go" decisions so that we can explain them in the future.

\section{Action Items}

\section{Mapping}

- Work with ExCos to draft statements summarizing annex activities,

- For a brief summary of each annex:

o Area of focus,

o Deliverables,

o Participation costs, and

o Manager.

- Do not waste time on annexes that hold little interest or have little strategic value,

- Draft a consistent decision protocol for entrance into and exit from annexes and to help with funding decisions and approach (e.g., direct funding to lab, in-kind funding with industry). Include the protocol in Ops.,

- Review the MYPPs and identify weaker areas where annex activities may add strength,

- Map PVPS to solar MYPP,

- Map beyond IEA international activities and assess overall international exposure, including bilateral agreements, ISO, APP, and APEC,

- Add a section to each MYPP on international activities,

- Look for synergies with World Bank global climate change strategy and use IEA as a means of ensuring that developing countries do not become dumping grounds for inefficient/substandard products, and

- Set key criteria for entry into annexes:

o Serves U.S./DOE/BTP strategic interests.

o Concerns a technical area where there is research excellence outside the United States.

o Is consistent with U.S. policy goals (e.g., climate change mitigation).

0 Is in area where government has a clear role to play and a reason to be involved and/or where industry's legitimacy is questioned (e.g., standardsetting).

\section{Funding}

- Be explicit and specific about IA/annex funding needs in AOPs, and identify connections between MYPP and AOP priorities and their linkages to IEA activities,

- Consider funding IEA dues through BTP "taxes," but fund annex work via AOPs, and

- Travel planning and budgeting must be robust since there have been large travel budget cuts. Try to anticipate IEA-related travel well in advance (even as far as two years in advance) so that BTP can attempt strategically to secure blocks of travel funding from EE. IEA travel should not be done on a retail basis. 


\section{National Teams}

- National Teams may make most sense when:

o Work is focused (as in HPP) rather than diffuse (as in ECBCS),

o IA operating agent has the capacity to manage the team, and

o Little or no funding is involved.

- National Teams need not be highly formalized or structured. They could take the form of industry working groups and could operate on an ad hoc basis.

\section{Internal Communications}

- Focus energies primarily on internal communications and improving visibility of IEA activities, since information flows within DOE are not good,

- Consider using EE international activities website as a communication platform for IEA-related activities,

- Provide time at BTP staff meetings for debrief of recent developments regarding international travel and activities,

- Institute annual IEA/International Activity Symposia within BTP, possibly linking to the strategic planning/integration meeting this fall,

- Involve and inform BTP managers at each step along the way with regard to international activities and provide them with clear information on the purpose and relevance of international activities and travel. Approvals are more readily obtained when complete information is forthcoming, and

- Activities must be justifiable to both BTP and EE.

\section{External Communications}

- Issue "progress alerts" for international activities just as we do for domestic activities and do web posting and press releases,

- Invite ExCo representatives from other parts of EE to fall IEA Symposium,

- Form an international activities working group within BTP and institute quarterly meetings, and

- Make IA/annex-related costs more visible by including them in AOPs. 


\section{Agenda of IEA Day: Workshop on Implementing Agreements}

May 8, 2008, 9:00 to 1:00

BTP Conference Room

950 L'Enfant Plaza, Suite 600 - Conference Room: 6097 - 6099

1. Welcome and Introduction (Jerry Dion) $10 \mathrm{~min}$.

2. Brief Overview of Implementing Agreements (30 min., presented by LBNL and PNNL):

a. How IAs work

b. Summary of evaluation results

3. How relevant are the IAs to BTP? (1.5 hours)

a. Strategic mapping exercise (presented by PNNL and LBNL)

b. Brief BTP program manager presentations on IAs (highlights of particularly relevant or useful recent findings; no slides required)

c. Discussion on strategic relevance

4. National Teams and Communications (30 min.)

a. Issues (presented by PNNL and LBNL)

b. Discussion

5. Next Steps (Brainstorm for 30 minutes)

6. Conclusions (Jerry Dion, 15 min.) 


\section{Appendix J. List of Acronyms}

\begin{tabular}{|c|c|}
\hline AIVC & Air Infiltration and Ventilation Centre (ECBCS Annex 5) \\
\hline ANSI & American National Standards Institute \\
\hline ASHRAE & $\begin{array}{l}\text { American Society of Heating, Refrigerating and Air Conditioning } \\
\text { Engineers }\end{array}$ \\
\hline BEopt & Building design optimization software (for zero energy buildings) \\
\hline BESTEST & Building Energy Simulation Test \\
\hline BTP & U.S. Department of Energy Building Technologies Program \\
\hline CBI & Commercial Buildings Integration (title of a Multi-Year Project Plan) \\
\hline CERT & Committee on Energy Research (at the IEA) \\
\hline $\mathrm{CFC}$ & chlorofluorocarbon \\
\hline $\mathrm{CO}_{2}$ & carbon dioxide \\
\hline COGEN-SIM & $\begin{array}{l}\text { Simulation of Building-Integrated Fuel Cell and other Cogeneration } \\
\text { Systems (Annex 42, ECBCS) }\end{array}$ \\
\hline DOE & U.S. Department of Energy \\
\hline DSB & Demand-Side Bidding \\
\hline DSM & $\begin{array}{l}\text { Demand-Side Management or Demand-Side Management Implementing } \\
\text { Agreement (www.ieadsm.org) }\end{array}$ \\
\hline ECBCS & $\begin{array}{l}\text { Energy Conservation in Buildings and Community Systems } \\
\text { (www.ecbcs.org) }\end{array}$ \\
\hline ESCO & Energy Service Company \\
\hline EU & European Union \\
\hline ExCo & Executive Committee (of an implementing agreement) \\
\hline $4 \mathrm{E}$ & $\begin{array}{l}\text { Energy Efficiency Electrical Equipment Implementing Agreement; also } \\
\text { known as the Efficient Appliances Implementing Agreement (www.iea- } \\
\text { 4e.org) }\end{array}$ \\
\hline HiPTI & High Performance Thermal Insulation Systems (Annex 39, ECBCS) \\
\hline $\mathrm{HP}$ & $\begin{array}{l}\text { Heat Pumping Technologies Implementing Agreement } \\
\text { (www.heatpumpcentre.org) }\end{array}$ \\
\hline HVAC & Heating, ventilation and air conditioning \\
\hline IA & Implementing agreement \\
\hline IEA & International Energy Agency \\
\hline INDEEP & $\begin{array}{l}\text { International Database on Demand-Side Management Technologies and } \\
\text { Programs (DSM Task 1) }\end{array}$ \\
\hline LBNL & Lawrence Berkeley National Laboratory \\
\hline MOIST-EN & Whole Building Heat Air and Moisture Response (Annex 41, ECBCS) \\
\hline MYPP & Multi-Year Project Plan \\
\hline NREL & National Renewable Energy Laboratory \\
\hline OECD & Organisation for Economic Co-operation and Development \\
\hline OIP & U.S. Department of Energy's Office of Industrial Programs \\
\hline ORNL & Oak Ridge National Laboratory \\
\hline PNNL & Pacific Northwest National Laboratory \\
\hline PV & Photovoltaic \\
\hline $\mathrm{PV} / \mathrm{T}$ & Photovoltaic/Thermal \\
\hline
\end{tabular}


R\&D Research and development

SHC

Solar Heating and Cooling Implementing Agreement (www.iea-shc.org)

SLT

Standing Group on Long-Term Co-operation (at the IEA)

ZEB

Zero-energy building

$\mathrm{ZEH}$

Zero-energy home 


\section{References}

Bouza, Antonio. 2008. IEA Implementing Agreement: Heat Pumping Technologies

Programme (HHP). U.S. Department of Energy, Washington, DC.

Building Technologies Program and the International Energy Agency. 2008. "IEA Implementing Agreements: Energy Conservation in Buildings and Community Systems \& Heat Pumping Technologies Programme." Presentation provided by U.S. Department of Energy Building Technologies Program, Department of Energy, Washington, DC.

Demand Side Management Implementing Agreement Website, http://62.121.14.21/.

DSM Implementing Agreement. 2003. 2002 Annual Report. Executive Secretary of DSM IA, Stockholm, Sweden.

DSM Implementing Agreement. 2004. 2003 Annual Report. Executive Secretary of DSM IA, Stockholm, Sweden.

DSM Implementing Agreement. 2005. 2004 Annual Report. Executive Secretary of DSM IA, Stockholm, Sweden.

DSM Implementing Agreement. 2006. 2005 Annual Report. Executive Secretary of DSM IA, Stockholm, Sweden.

DSM Implementing Agreement. 2007. 2007 Annual Report [draft]. Executive Secretary of DSM IA, Stockholm, Sweden.

Department of Energy (DOE). 2008. “Analysis Tools Draft Technology R\&D Multi-Year Plan (FY 2008-FY 2013),” Washington, DC. (Internal working document).

DOE. 2007. "Building Envelopes Multi-Year Plan, 2008-2012," Washington, DC. (Internal working document).

DOE. 2008. "Commercial Buildings Integration Multi-Year Program Plan, FY 2008 - 2013," Washington, DC. (Internal working document).

DOE. 2007. "HVAC: Draft Technology R\&D Multi-Year Plan.” Version 11, Washington, DC. (Internal working document).

DOE. 2007. "Residential Integration Status: Multi-Year Plan," Washington, DC. (Internal working document).

DOE. 2007. "Multi-Year Program Plan FY'08-FY'13. Solid-State Lighting Research and Development," Washington, DC. (Internal working document).

DOE. 2007. “Windows Multi-Year Plan,” Washington, DC. (Internal working document). 
Energy Conservation in Buildings and Community Systems, Implementing Agreement Website, http://www.ecbcs.org/.

Heat Pump Centre Website, http://www.heatpumpcentre.org/.

Indinger, Andreas. Feb. 2005. Research Activities of the International Energy Agency. The Austrian Energy Agency, Vienna.

International Energy Agency. June 2002. Criteria and Review Process for the Extension of Implementing Agreements. International Energy Agency, Committee on Energy Research and Technology, Paris.

International Energy Agency. 2008. Implementing Agreement for a Co-Operative Programme on Efficient Electrical End-Use Equipment. International Energy Agency, Paris.

International Energy Agency. June 2005. Implementing Agreement for a Programme of Research and Development on Energy Conservation in Buildings and Community Systems. International Energy Agency, Paris.

International Energy Agency. November 2006. Implementing Agreement for a Programme of Research, Development, Demonstration, and Promotion of Heat Pumping Technologies. International Energy Agency, Paris.

International Energy Agency. October 2005. Implementing Agreement for a Programme to Develop and Test Solar Heating and Cooling Systems. International Energy Agency, Paris.

International Energy Agency. October 2006. Implementing Agreement for Co-Operation on Technologies and Programmes for Demand-Side Management. International Energy Agency, Paris.

International Energy Agency. July 2004. Implementing Agreement on Demand Side Management Technologies and Programmes, INDEEP Analysis Report July 2004. International Energy Agency, Paris.

International Energy Agency ,Committee on Energy Research and Technology. January 2002. "Extension of Four Implementing Agreements (Note by the Secretariat)." Document No. (2002)25. International Energy Agency, Paris.

International Energy Agency, Committee on Energy Research and Technology. November 2002. "Implementing Agreement Decisions: Extension of Three Implementing Agreements (Note by the Secretariat)." Document No. IEA/CERT. International Energy Agency, Paris.

International Energy Agency, Committee on Energy Research and Technology. October 2003. "Update on Advisory Groups (Note by the Secretariat)." Document No. IEA/CERT. International Energy Agency, Paris. 
International Energy Agency, Committee on Energy Research and Technology. October 2003. "Extension of an Implementing Agreement for a Programme to Develop and Test Solar Heating and Cooling Systems (Note by the Secretariat)." Document No. (2003)40. International Energy Agency, Paris.

International Energy Agency, Demand Side Management Programme Homepage, http://www.iea.org/Textbase/techno/iaresults.asp?id_ia=8.

International Energy Agency, Energy Conservation in Buildings and Community Systems Programme Homepage, http://www.iea.org/Textbase/techno/iaresults.asp?id_ia=12.

International Energy Agency Heat Pumping Technologies Programme Homepage, http://www.iea.org/Textbase/techno/iaresults.asp?id_ia=21.

International Energy Agency, Solar Heating and Cooling Programme Homepage, http://iea.org/Textbase/techno/iaresults.asp?id_ia=36.

International Energy Agency, Technology Agreements Homepage, http://www.iea.org/Textbase/techno/index.asp.

Malme, Ross. December 2006. "European and Australian Final Seminars." (memo)

Malme, Ross. 2006. "International Energy Agency Demand Side Management Programme. Task XIII: Demand Response Resources. Final Task XIII Status Report.".

Scarpelli, Pete. 2006. "An Overview of International Energy Agency Demand Side Management Program. Task XIII: Demand Response Resources." Prepared for Federal Energy Regulatory Commission's Technical Conference on Demand Response and Advanced Metering. Chicago, IL.

Solar Heating and Cooling Implementing Agreement, http://www.iea-shc.org/.

Summary of the IEA Evaluation. 2005. Project Management Julich. (evaluation prepared for the German government).

U.S. Department of Energy. "Energy Conservation in Buildings and Community Systems Implementing Agreement." International Energy Agency Building Technologies Program, U.S. Department of Energy (PowerPoint presentation).

Wagner, Caroline S., Linda Staheli, Richard Silberglitt, Anny Wong, and James Kadtke. April 2002. Linking Effectively: Learning Lessons From Successful Collaboration in Science and Technology. Science and Technology Policy Institute. 